\title{
Bentonite and Fuller's Earth Resources of the United States
}

U.S. GEOLOGICAL SURVEY PROFESSIONAL PAPER 1522

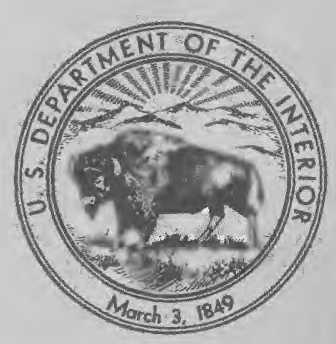




\section{Bentonite and Fuller's Earth Resources of the United States}

By JOHN W. HOSTERMAN and SAM H. PATTERSON

U.S. GEOLOGICAL SURVEY PROFESSIONAL PAPER 1522

A compilation on the uses, geology, mineralogy, and distribution of bentonite and fuller's earth in the United States

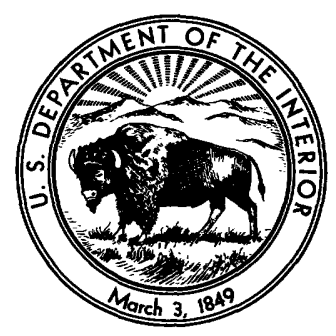

UNITED STATES GOVERNMENT PRINTING OFFICE, WASHINGTON：1992 


\title{
U.S. DEPARTMENT OF THE INTERIOR \\ MANUEL LUJAN, Jr., Secretary
}

\section{U.S. GEOLOGICAL SURVEY}

\author{
Dallas L. Peck, Director
}

\begin{abstract}
Any use of trade, product, or firm names in this publication is for descriptive purposes only and does not imply endorsement by the U.S. Government
\end{abstract}

\section{Library of Congress Cataloging in Publication Data}

Hosterman, John W. (John Wallace), 1923-

Bentonite and fuller's earth resources of the United States / by John W. Hosterman and Sam H. Patterson. p. cm.-(U.S. Geological Survey professional paper ; 1522) Includes bibliographical references.

1. Bentonite deposits-United States. 2. Fuller's earth-United States. 3. Bentonite. I. Patterson, Sam H. (Sam Hunting), 1918-. II. Title. III. Series.

TN948. B4H67 1992

553.6 ' $1-$ dc20

91-13033

For sale by Book and Open-File Report Sales, U.S. Geological Survey, Federal Center, Box 25286, Denver, CO 80225 


\section{CONTENTS}

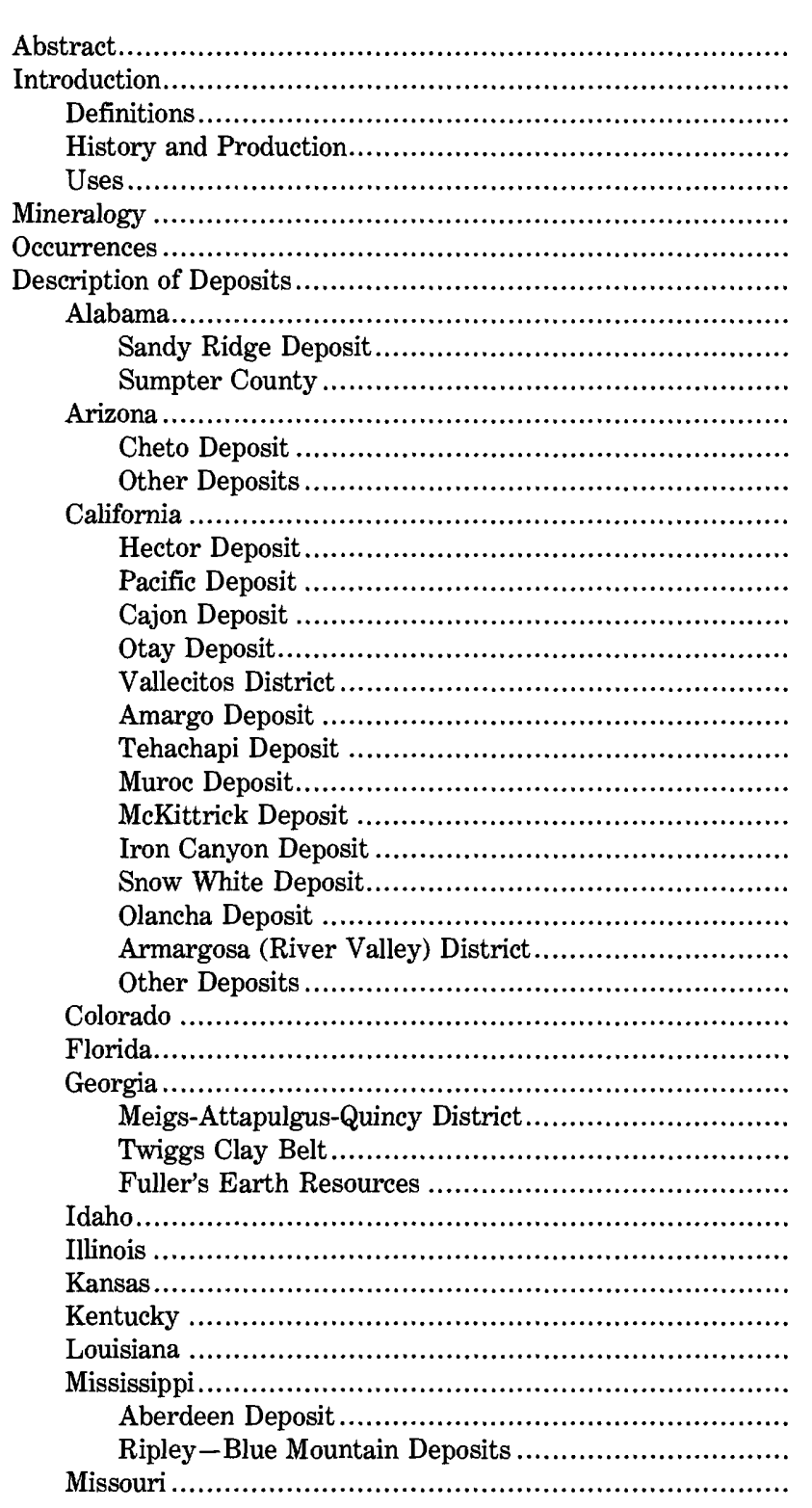

\begin{tabular}{|c|c|}
\hline age & \\
\hline 1 & Description of Deposits-Continued \\
\hline 1 & 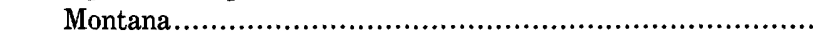 \\
\hline 1 & Hardin District................ \\
\hline 2 & Malta-Glasgow District ..... \\
\hline 3 & Vananda District ............... \\
\hline 5 & Bentonite Resources ........... \\
\hline 12 & Nevada... \\
\hline 14 & McDermitt Hectorite......... \\
\hline 14 & Ash Meadows Deposits .... \\
\hline 14 & Beatty Deposit...... \\
\hline 17 & Blanco Deposit ..... \\
\hline 17 & Bluff Deposit ................. \\
\hline 17 & 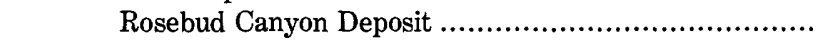 \\
\hline 18 & 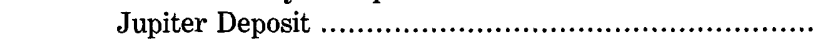 \\
\hline 20 & Walker Lake Deposits ...................................... \\
\hline 20 & 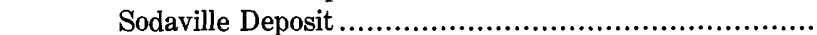 \\
\hline 20 & 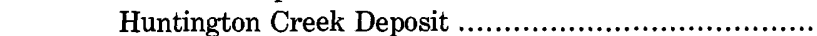 \\
\hline 21 & 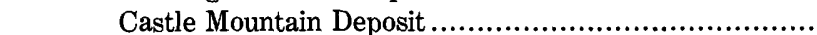 \\
\hline 21 & 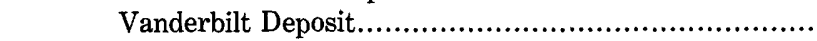 \\
\hline 21 & eposits ..................... \\
\hline 21 & New Mex \\
\hline 21 & North Dal \\
\hline 22 & Oklahoma \\
\hline 22 & Oregon. \\
\hline 22 & South Carolina ........................ \\
\hline 22 & South Dakota........................... \\
\hline 22 & Tennessee ................................ \\
\hline 22 & Texas ......................................... \\
\hline 23 & Lufkin Deposits.................... \\
\hline 23 & 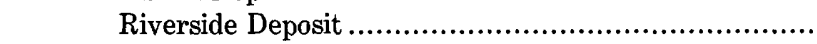 \\
\hline 23 & 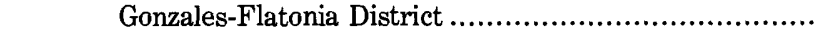 \\
\hline 24 & Other Deposits ................... \\
\hline 24 & Utah.... \\
\hline 24 & Virginia and Maryland.. \\
\hline 25 & Washingt \\
\hline 25 & Wyomin \\
\hline 25 & (......................................... \\
\hline 26 & (........................................... \\
\hline 26 & 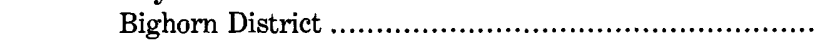 \\
\hline 26 & 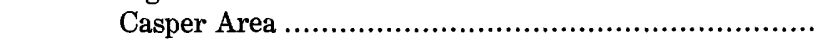 \\
\hline 26 & 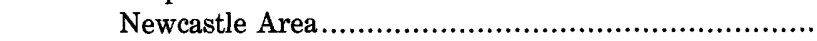 \\
\hline 26 & Bentonite Resources \\
\hline 27 & ion \\
\hline 27 & (2) \\
\hline
\end{tabular}




\section{ILLUSTRATIONS}

Plate 1. Bentonite and fuller's earth resources of the United States In pocket

FIGURES 1-7. Graphs showing:

1. U.S. bentonite production...

2. U.S. fuller's earth production

3. X-ray diffraction trace of sodium-bentonite (montmorillonite) from the Clay Spur Bentonite Bed of the Mowry Shale, Crook County, Wyo....

4. X-ray diffraction trace of calcium-bentonite (montmorillonite) from the Yegua Formation, Claiborne Group, Gonzales County, Tex.

5. X-ray diffraction trace of magnesium-bentonite (saponite) from Pleistocene tuffaceous playa beds, Nye County, Nev.

6. X-ray diffraction trace of lithium-bentonite (hectorite) from the Hector deposit, San Bernardino County, Calif.

7. X-ray diffraction traces of bentonite (CSB-1) from Crook County, Wyo., and palygorskite (ATT-1) from Gadsden County, Fla.

8. Stratigraphic chart showing the geologic formations and bentonite beds of the Montana and Wyoming bentonite districts

9. Map showing the outcrop belt of the Porters Creek Clay (Formation) in Georgia, Alabama, Mississippi, Tennessee, Kentucky, Illinois, Missouri, and Arkansas.......

10. Stratigraphic chart showing some formations and groups of formations of the Gulf of Mexico Coastal Plain..

11. Map showing location of Wyoming bentonite deposits discussed in this report.

\section{TABLES}

\section{METRIC CONVERSION FACTORS}

This report uses the metric units listed below. To convert to inch-pound units, use the conversion factors given below.

\begin{tabular}{rll}
\hline Multiply & By & To obtain \\
\hline millimeter $(\mathrm{mm})$ & 0.03937 & inch (in) \\
centimeter $(\mathrm{cm})$ & 0.3937 & inch (in) \\
meter $(\mathrm{m})$ & 3.281 & foot $(\mathrm{ft})$ \\
kilometer $(\mathrm{km})$ & 0.6214 & mile $(\mathrm{mi})$ \\
square hectometer $\left(\mathrm{hm}^{2}\right)$ & 2.471 & acre \\
metric ton & 1.102 & short ton $(2,000$ pounds) \\
kilogram $(\mathrm{kg})$ & 2.205 & pound \\
\hline
\end{tabular}




\title{
BENTONITE AND FULLER'S EARTH RESOURCES OF THE UNITED STATES
}

\author{
By John W. Hosterman ${ }^{1}$ and Sam H. Patterson
}

\begin{abstract}
The term bentonite is defined as any natural material composed dominantly of the clay minerals of the smectite group and whose properties are controlled by these clay minerals. Fuller's earth refers to naturally occurring material that has a high absorptive capacity.

Both bentonite and fuller's earth have a wide variety of physical properties that make them suitable for many commercial uses and applications. The sodium or Wyoming bentonite is a high swelling variety used in drilling muds, bonding foundry sand, and pelletizing taconite iron ores. The calcium or southern bentonite is a low or nonswelling variety used for bonding foundry sand where a highstrength green bond is required. Large amounts of fuller's earth are utilized to make granules that are used as an absorbent for oils, grease, chemicals, as an animal litter, and as a soil conditioner.

Almost all of the commercial deposits of bentonite and fuller's earth are in geologic formations that are either Cretaceous or Tertiary in age. Bentonite occurs in Tertiary rocks in the Atlantic Coastal Plain, the Gulf of Mexico Coastal Plain, and in the Mississippi embayment. The best grade swelling bentonite occurs in the Mowry Shale of Cretaceous age in Wyoming and Montana. The most abundant nonswelling bentonite is found in Tertiary formations of the Jackson and Claiborne Groups in Texas. An important geologic unit for fuller's earth deposits is the Tertiary Hawthorn Formation of Georgia and Florida.

In 1988, almost 75 percent of the bentonite production in the United States came from Wyoming. Alabama and Mississippi together produced about 14 percent; California produced about 4 percent, and Arizona, Texas, and Utah each produced about 1 percent. States producing less than 1 percent of the U.S. bentonite were Colorado, Idaho, Kansas, Montana, Nevada, Oregon, and Tennessee. In 1988, almost 50 percent of the fuller's earth produced in the United States came from Georgia and Florida. Other States producing fuller's earth were Illinois, Mississippi, Missouri, Nevada, South Carolina, Tennessee, Texas, and Virginia.
\end{abstract}

\section{INTRODUCTION}

The U.S. Geological Survey investigated the bentonite deposits of Wyoming and Montana during the periods 1946-51 and 1982, the fuller's earth deposits of Georgia and Florida during the period 1963-69, the bentonite deposits of the Gulf of Mexico Coastal Plain during 1981-82, and the bentonite deposits of Nevada and

\footnotetext{
Manuscript approved for publication March 25, 1991.

${ }^{1}$ Deceased.
}

California in 1983. From these investigations, a great deal of data was obtained on the mineralogy, chemistry, and physical properties from the many samples of bentonite and fuller's earth that were collected. In addition, many western State Geological Surveys have published detailed information of the bentonite deposits and occurrences within their respective States. This report is a compilation of the data collected and a review of the pertinent literature available on the bentonite and fuller's earth deposits in the United States.

The report gives the definitions of bentonite and fuller's earth and describes the mineralogical, chemical, and physical differences between them. Also included is a brief discussion on the history, production, and uses. The remainder of the report provides information on the known bentonite and fuller's earth deposits and the potential resources of bentonite and fuller's earth in 27 different States.

\section{DEFINITIONS}

The term bentonite was first proposed in 1898 by Knight (1898) for the unusual clay found on the Taylor Ranch near Rock River, Wyo. He had originally wanted to use the name taylorite after William Taylor, the owner of the ranch, but the name taylorite was preoccupied. The name bentonite, which Knight (1898) introduced as a replacement for taylorite, is from the Benton Shale-the formation in which the clay was thought to occur at that time. The Benton Shale was named after Fort Benton, Mont., which is located more than $640 \mathrm{~km}$ northwest of Rock River. Formerly this clay had been referred to as mineral soap or soap clay because of its soaplike characteristics. Endleman (1858, p. 489) apparently was the first to describe the clay in writing as being "a layer of yellow unctuous (greasy-feeling) matter covered on the surface with efflorescence salts, which seemed to be a product of the decomposition of igneous rocks. It readily imbibes water and thereby increases much in volume and 
becomes plastic." Endleman also reported this material as being associated with rocks that are typical of the Mowry Shale of Cretaceous age. The absorbent and swelling capacity of Wyoming-type bentonite is its most important identifying physical characteristic.

The first comment on the origin of bentonite beds that formed from volcanic ash in the Great Plains region was in a report by Condra (1908, p. 13). According to this report, a thin bed that appeared to be a bentonite was considered by Professor J.E. Todd to have been derived from a volcanic ash. Later Hewitt (1917, p. 197) and Wherry (1917) established that the bentonite beds of the northern Great Plains were formed from altered volcanic ash. The definition most widely quoted and generally accepted is the following definition by Ross and Shannon (1926, p.77):

Bentonite is a rock composed essentially of a crystalline clay-like mineral formed by devitrification and the accompanying chemical alteration of a glassy igneous material, usually a tuff or volcanic ash: and it often contains variable proportions of accessory crystal grains that were originally phenocrysts in the volcanic glass. These are feldspar (commonly orthoclase and oligoclase), biotite, quartz, pyroxenes, zircon, and various other minerals typical of volcanic rocks. The characteristic clay-like mineral has a micaceous habit and facile cleavage, high birefringence and a texture inherited from volcanic tuff or ash, and it is usually the mineral montmorillonite, but less often beidellite.

The prevailing acceptance of the idea that bentonite formed from the alteration of volcanic ash has resulted in the general misapplication of the name bentonite to any altered volcanic ash bed without regard for the definitive physical characteristics of true bentonite. According to Grim and Güven (1978, p. 131-135), many authors have shown that bentonite is derived from the alteration of other types of igneous rock and not exclusively from volcanic ash. Such evidence precludes a definition of bentonite based solely on altered volcanic ash as its parent material or source rock. It is, therefore, appropriate to follow the suggestion of Grim and Güven (1978, p. 1) that restricts the term bentonite to clays composed predominantly of a smectite group mineral and that have the chemical and physical properties of that mineral, without regard to origin. Hectorite, a variety of smectite that contains magnesium and lithium, is considered to be a bentonite.

The term fuller's earth comes from its former use, which was for cleaning or fulling wool by individuals who were known as fullers. Its origin dates back to antiquity and was applied to any fine-grained earthy material used in cleaning wool. Calcium-bentonite and palygorskite are now used for preparing wool because they are more efficient as cleaning agents. In addition, the meaning of fuller's earth has undergone several changes because these clay materials are also used for other purposes.
Robertson (1986) has published an interesting book on the history of fuller's earth from ancient Egypt to modern times.

Today, fuller's earth refers to any clay material that has the capacity to decolorize oil or other liquids, without chemical treatment, to the extent that it improves the commercial value of that oil or liquid. Such clay has been referred to as naturally active (Nutting, 1943) to distinguish it from activated clay, which requires acid treatment to be of value in purifying oils. The term does not imply any mode of origin, but fuller's earth is generally composed of the minerals palygorskite (attapulgite) or calcium-smectite (bentonite). However, not all smectites have the decolorizing capacity that is necessary for them to be called fuller's earth, and some have to be treated with acid before they make good fuller's earth.

As a consequence of the definition by Grim and Güven (1978, p. 1), many bentonite and bentonitic clay deposits, composed of smectite-group minerals, are now considered fuller's earth. This includes the extensive bentonitic clay beds in the Twiggs Clay Member of the Dry Branch Formation (Barnwell Group) in Georgia and the Porters Creek Clay in Missouri, Illinois, Kentucky, Tennessee, Mississippi, and Alabama.

\section{HISTORY AND PRODUCTION}

The American Indians were evidently the first to use bentonite for its adsorptive properties. According to one Indian legend, a deposit of natural clay of miraculous medicinal qualities was used by the medicine men in the Bighorn Mountains of Wyoming and Montana. The Indians called this clay "ee-wah-kee," meaning "the mud that heals" (H.H. Tiffany, written commun., 1966). The early pioneers used bentonite from outcrops called "soap holes" to wash their clothes and to lubricate their wagon wheels (Thorson, undated).

The first known shipment of bentonite, for commercial purposes in the United States, was made in 1888 from Rock River, Albany County, Wyo., by William Taylor (Darton and Siebenthal, 1909, p. 60). The crude clay was shipped to Philadelphia, Pa., where it sold for $\$ 25$ a ton and was used in cosmetics. The first bentonite mining in the Black Hills area of Wyoming began in 1897 near Newcastle (Heathman, 1939). Clay from the mine was dried by hand by raking it over steel plates that were heated by wood or coal fires.

According to Patterson (1974, p. 14), fuller's earth was discovered in the United States in 1893 near Quincy, Fla., by the Owl Commercial Co. (predecessor of present makers of White Owl cigars) during an attempt to burn bricks made from the clay found on one of its properties. An Alsatian immigrant recognized that the clay was similar to the clays used in Germany for fulling. His 


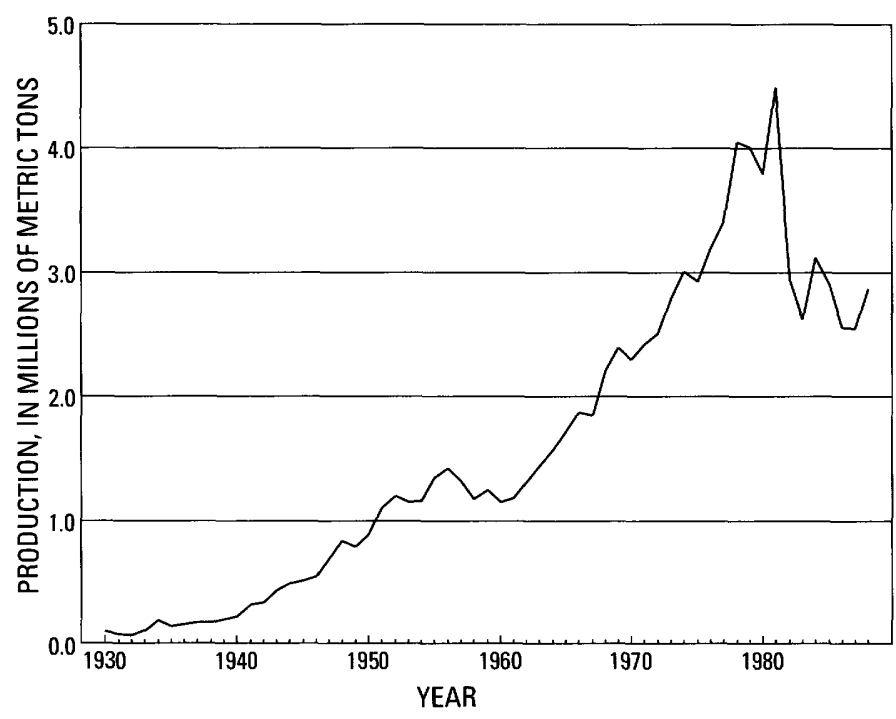

FIGURE 1.-U.S. bentonite production (U.S. Bureau of Mines, 1930-89).

observation led to the opening of the first attapulgite mine near Quincy 2 yr later.

Bentonite, used as a fuller's earth, has been produced in Texas since 1907, but the industry did not become important until 1920 (Phillips and Phillips, 1935). In 1918, the largest bentonite mine was about $26 \mathrm{~km}$ south of San Antonio. However, in 1931, this mine was abandoned in favor of higher grade bentonite deposits in Fayette and Gonzales Counties, about $160 \mathrm{~km}$ east of San Antonio (King, 1940).

The U.S. Bureau of Mines (USBM) began keeping production records in 1930 for bentonite and in 1935 for fuller's earth (U.S. Bureau of Mines, 1930-89). In 1930, the United States produced slightly less than 100,000 metric tons ( $\mathrm{t}$ ) of bentonite. This production increased to almost 4.5 million metric tons (Mt) in 1981 but declined to about $2.5 \mathrm{Mt}$ in 1986 (fig. 1). This decrease was due to a sharp decline in the number of wells drilled by the petroleum industry. An additional future decline in the use of bentonite may result if the iron and steel industry shifts from bentonite to an organic binder in pelletizing taconite ore (Haas and others, 1989). The USBM production records for fuller's earth are divided into two categories - attapulgite and bentonite. In 1935, the production of fuller's earth was about 207,000 Mt, and in 1985, production was slightly more than 1.8 Mt (fig. 2). This production increase is due to the demand for clay having absorbent properties for uses in animal litter and as a carrier for insecticides and fungicides.

\section{USES}

The uses of bentonite and fuller's earth are interrelated and overlap. The major uses of bentonite are in

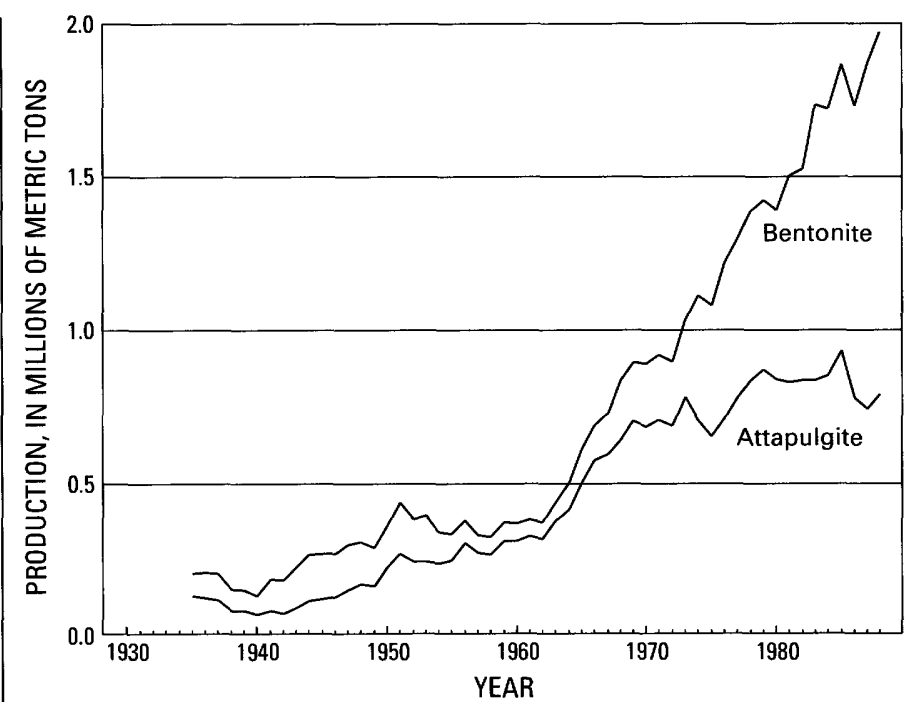

FIGURE 2. -U.S. fuller's earth production (U.S. Bureau of Mines, 1930-89).

drilling mud, foundry-sand bond, binder for pelletizing iron ore, and for bleaching liquids (filtering, clarifying, and decolorizing). The minor uses include carrier for pesticides and fertilizers, filler in paint, adhesive, and pharmaceutical products, binder for animal feed, sealant for waterproofing reservoirs and canals, and as a catalyst for oil refining. The major use of fuller's earth, since the early 1960 's, has been in absorbents for oil, grease, and animal waste and as a carrier for pesticides and fertilizers. The minor uses include filtering, clarifying, and decolorizing and filler in paint, adhesives, and pharmaceutical products.

The use of bentonite as soil liners and in the treatment of water has become popular in Texas where there is a demand for containing petrochemical waste dumps and treating industrial ponds. A new use for bentonite is with polyacrylamide in making paper (O'Driscoll, 1988, p. 50).

Drilling mud.-Bentonite is used in drilling mud to keep the cutting tools cool, to remove cuttings, to lubricate the drill bit, to confine fluids by building an impervious coating on the wall of the drill hole, and to help prevent blowouts(Larsen, 1955). The mud is pumped, under pressure, down through the drill pipe and out through the bit at the bottom of the hole. The cuttings are picked up and carried to the surface through the annular space between the drill pipe and the wall of the hole. Approximately 46 percent of the U.S. bentonite production and almost 2 percent of the fuller's earth production are used in drilling mud (Ampian, 1988). Hectorite, sodium-bentonite, and attapulgite make the best grade clay drilling muds. However, some of the calcium-bentonite produced in Texas can be used after treatment with sodium hydroxide $(\mathrm{Na}(\mathrm{OH}))$ to improve 
its swelling properties by exchanging the cation from calcium to sodium (Fisher, 1965, p. 168). Both hectorite and bentonite will flocculate in saltwater; therefore, they can only be used in drill holes that encounter only freshwater. Attapulgite is used where saltwater is expected because it will not flocculate in saltwater.

Foundry-sand bond. - The value of bentonite for bonding foundry sand was recognized in the 1920's, and since then, the iron and steel foundries have been a major consumer of bentonite. About 27 percent of the bentonite produced was used for foundry-sand bond in 1986 (Ampian, 1988). In preparing foundry sands, a small amount of bentonite (approximately 4 percent by volume) is added to the sand and thoroughly mulled. A small amount of water (less than 1.5 percent by volume) is added. The mixture is thoroughly mulled again and formed into a mold. If the molten metal is poured into a mold that is still moist, it is known as the green process. If the molten metal is poured into a mold that has been dried and is free of moisture, it is known as the dry process. Grim (1962, p. 148-203) shows that sodium- and calcium-bentonites have distinctly different bonding properties. Sodium-bentonites have a low to moderate green strength and a very high dry strength, whereas calcium-bentonites have a high green strength and a low dry strength. As a result, the sodium-bentonites from Wyoming and Montana are used in foundries making large castings that require molds made by using the dry process. The calcium-bentonites from Mississippi, Alabama, and Texas are used in foundries making small castings that require molds that are made by using the green process. Sand molds that require intermediate green and dry strengths can be made by blending the sodium- and calcium-bentonites with the sand.

Iron ore pelletizer. - The principal source of iron in the United States is from the siliceous low-grade iron ore (taconite) deposits mined in the Lake Superior ironbearing district, Minnesota. The taconite iron ore is processed to increase the iron content by eliminating the impurities; the purified powder is blended with bentonite and pressed into pellets about $25 \mathrm{~mm}$ in diameter for use as basic oxygen furnace feed. The U.S. steel industry began this use of bentonite shortly after World War II (Patterson and Murray, 1975, p. 524). In 1986, approximately 12 percent of the bentonite produced in the United States was used as a binder for pelletizing iron ore (Ampian, 1988).

The green iron ore pellets must have sufficient strength to withstand handling, compaction, and drying, and the dry pellets must be even stronger to retain their shape during transportation and furnace charging. Several methods for testing bentonite for pelletizing iron ore have been published (Sastry and Fuerstenau, 1971; Wakeman, 1972). The properties for evaluating mixtures of bentonite, taconite ore, and water are wet-drop strength, wet compression strength, plastic deformation, and dry compression strength. The amount of bentonite used is less than $9 \mathrm{~kg} / \mathrm{t}$ of iron ore; therefore, the type of bentonite used must have a very high dry strength. The sodium-bentonite from Wyoming and Montana meets this demand. Although bentonite is unsurpassed as a pellet bond, it adds undesirable impurities to the iron ore.

Bleaching clay. - Some bentonites and attapulgite are used for decolorizing various mineral, vegetable, and animal oils. They are also used for clarifying wines, liquors, cider, beer, vinegar, and so forth. The acid activation process enhances the filtration properties of some bentonites several fold (Grim, 1962, p. 322). More than 6 percent of the bentonite and almost 1 percent of the fuller's earth are used in filtering, decolorizing, and clarifying purposes (Ampian, 1988). Both bentonite and fuller's earth are used together with alum in water clarification. The types of clay used are chiefly calciumbentonite from Arizona and Texas and attapulgite from Florida. The American Oil Chemists Society (A.O.C.S.) Official Method Cc 8b-52, revised April 1952, and A.O.C.S. Official Method Cc 8a-52, corrected 1958, outline the methods of testing clay for decolorizing (American Oil Chemists Society, 1958).

Absorbent. - Absorbent granules, 10-20 mesh in size, are made from bentonite and fuller's earth. The granules are made by calcining the bentonite or fuller's earth at $400-1,000{ }^{\circ} \mathrm{C}$ to increase absorbent capacity and by crushing and screening the calcined product to recover the desired particle size granules. Approximately 85 percent of the fuller's earth production in the United States is used as an absorbent, of which about two-thirds is used as pet waste absorbent and about one-third is used as oil and grease absorbent, (Ampian, 1988). Both attapulgite and calcium-bentonite are used. Some calcium-bentonite is produced as a desiccant and included in the fuller's earth production statistics.

Carrier. - Clay used as a carrier is important in attaining uniform dispersion of pesticides and fertilizers, retaining of the pesticides and fertilizers on plants, and preserving of pesticides and fertilizers. About 12 percent of the fuller's earth produced is used as a carrier for pesticides, fertilizers, and fire retardant (Ampian, 1988). Both attapulgite and calcium-bentonite are used for this purpose.

Filler.-Bentonite is used as a filler, stabilizer, and extender in materials such as adhesives, greases, medicines, cosmetics, paint, rubber, and soaps and as a bond in animal feed. Almost 6 percent of the bentonite and more than 1 percent of the fuller's earth production is used as a filler (Ampian, 1988). Calcium-bentonite is 


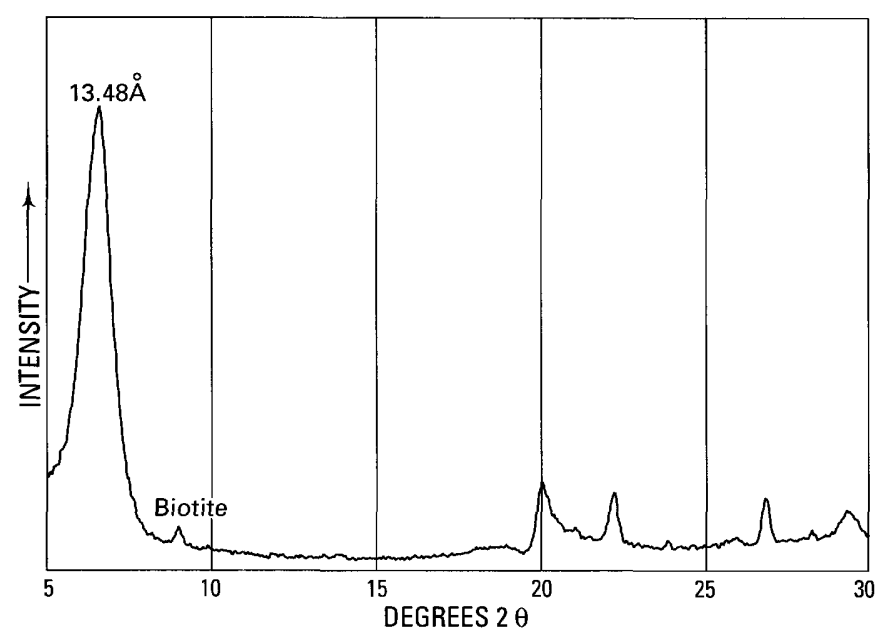

FigURE 3. -X-ray diffraction trace of sodium-bentonite (montmorillonite) from the Clay Spur Bentonite Bed of the Mowry Shale, Crook County, Wyo.

primarily used in animal feed, but both sodium-bentonite and attapulgite are used in all types of fillers.

Sealant and waterproofing.-Approximately 2 percent of the bentonite produced in the United States is used as a sealant to reduce water seepage from ponds and irrigation ditches (Ampian, 1988). It is also used to waterproof the outside basement walls of homes and other structures (Mielenz and King, 1955). Sodiumbentonite is the best type used for sealant and waterproofing because of its swelling capacity, but a small amount of calcium-bentonite is also used. There is probably a large quantity of bentonite and bentonitic clay used locally for sealing irrigation ditches and stock ponds that is not included in the U.S. Bureau of Mines annual production statistics.

Catalyst. -Small amounts of bentonite are used for catalytic cracking of heavy petroleum fractions (Grim, 1962 , p. 309). This use requires high-purity bentonite to be treated with sulfuric or hydrochloric acid to remove alkalies, alkaline earths, and iron and partially to remove magnesium and aluminum. Calcium-bentonite is the most suitable clay for this purpose.

\section{MINERALOGY}

Both bentonite and fuller's earth are rocks composed predominantly of one clay mineral plus small amounts of fine-grained nonclay minerals. Bentonite consists chiefly of one or more members of the smectite-group (formerly the montmorillonite-group) minerals. Fuller's earth also consists chiefly of either a smectite-group mineral or palygorskite (attapulgite).

The smectite minerals have a layered crystal structure in which two silica tetrahedral sheets, enclosing an alumina octahedral sheet, are separated by an interlayer

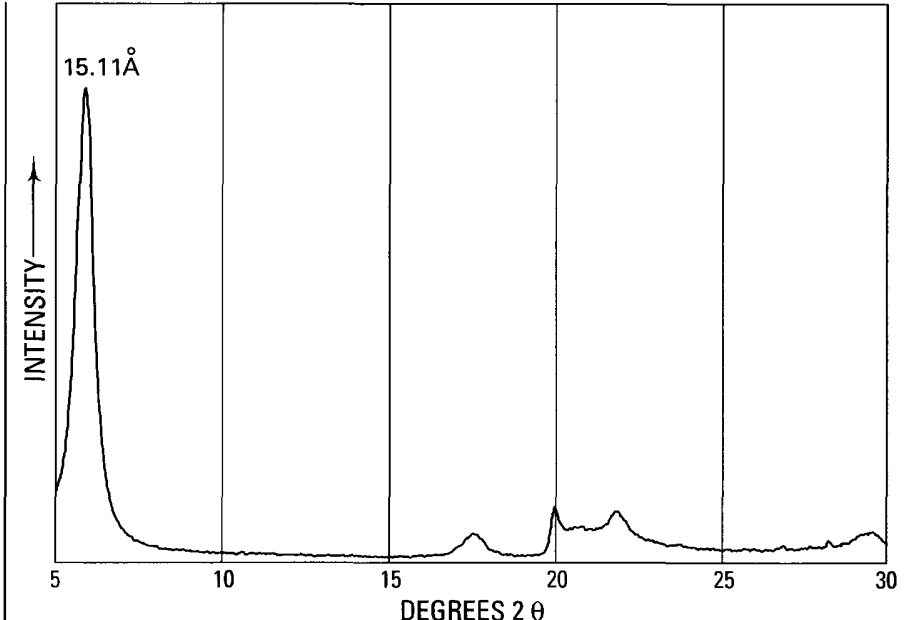

FIGURE 4.-X-ray diffraction trace of calcium-bentonite (montmorillonite) from the Yegua Formation, Claiborne Group, Gonzales County, Tex.

space containing an exchangeable ion(s) and water molecules. The theoretical formula is considered to be:

$$
\begin{gathered}
(\mathrm{OH})_{4} \mathrm{Si}_{8}\left(\mathrm{Al}_{3.34} \mathrm{Mg}_{0.66}\right) \mathrm{O}_{22} \\
\Downarrow \\
\mathrm{Na} \text { or } \mathrm{Ca}_{0.66} \cdot n \mathrm{H}_{2} \mathrm{O}
\end{gathered}
$$

The arrow indicates a charge deficiency that must be satisfied by an exchangeable ion in the interlayer space. Sodium is the dominant exchangeable ion in the Wyoming (Na or swelling) bentonites (fig. 3), and calcium is the dominant ion in the southern (Ca or nonswelling) bentonites (fig. 4). Smectite is recognized on the X-ray diffraction (XRD) traces by its very strong basal (001) peak at about $14 \AA$, which expands to about $17 \AA$ when saturated with ethylene glycol and collapses to $10 \AA$ when heated to $350{ }^{\circ} \mathrm{C}$ for a minimum of $30 \mathrm{~min}$.

The smectite-group minerals are divided into two subgroups - trioctahedral and dioctahedral. The trioctahedral smectites are represented by saponite (fig. 5) and hectorite (fig. 6) as end members of a magnesium-lithium series. The dioctahedral smectites are represented by beidellite, nontronite, and montmorillonite as end members of a aluminum-iron-magnesium series. For detailed discussion of the chemistry of the smectite-group minerals, the reader is directed to Ross and Hendricks (1945).

During the work leading to this report, the senior author investigated many deposits of bentonite and Wolfbauer (1977; Frahme (1978) reviewed a large quantity of data resulting from tests by the U.S. Bureau of Land Management. The U.S. Bureau of Land Management has also studied relation between the physical properties and exchangeable cations of bentonite (Regis, 1978a,b). The grit content, water-soluble salt content, and exchangeable cations of bentonite from many deposits in the United States are in table 1. 


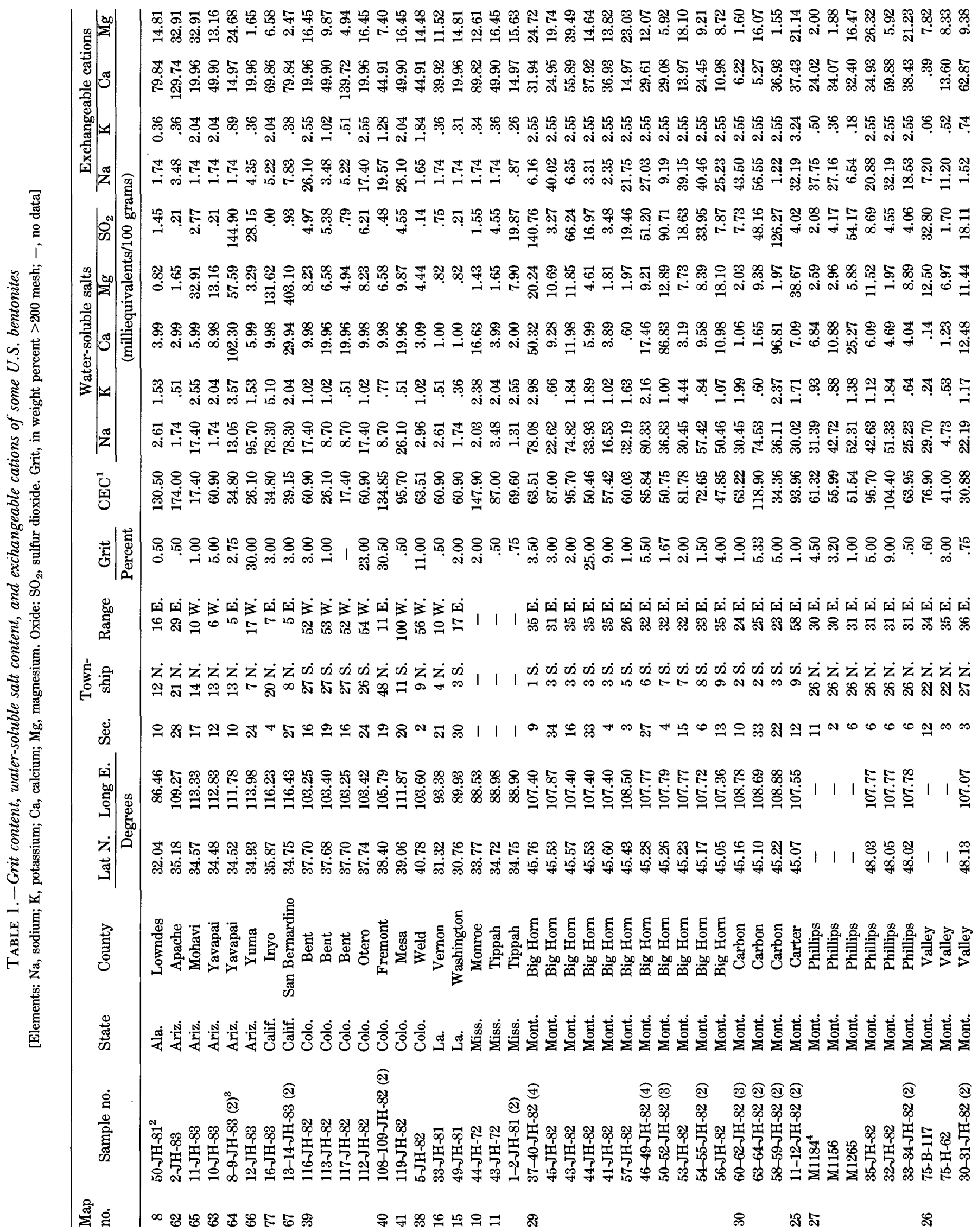




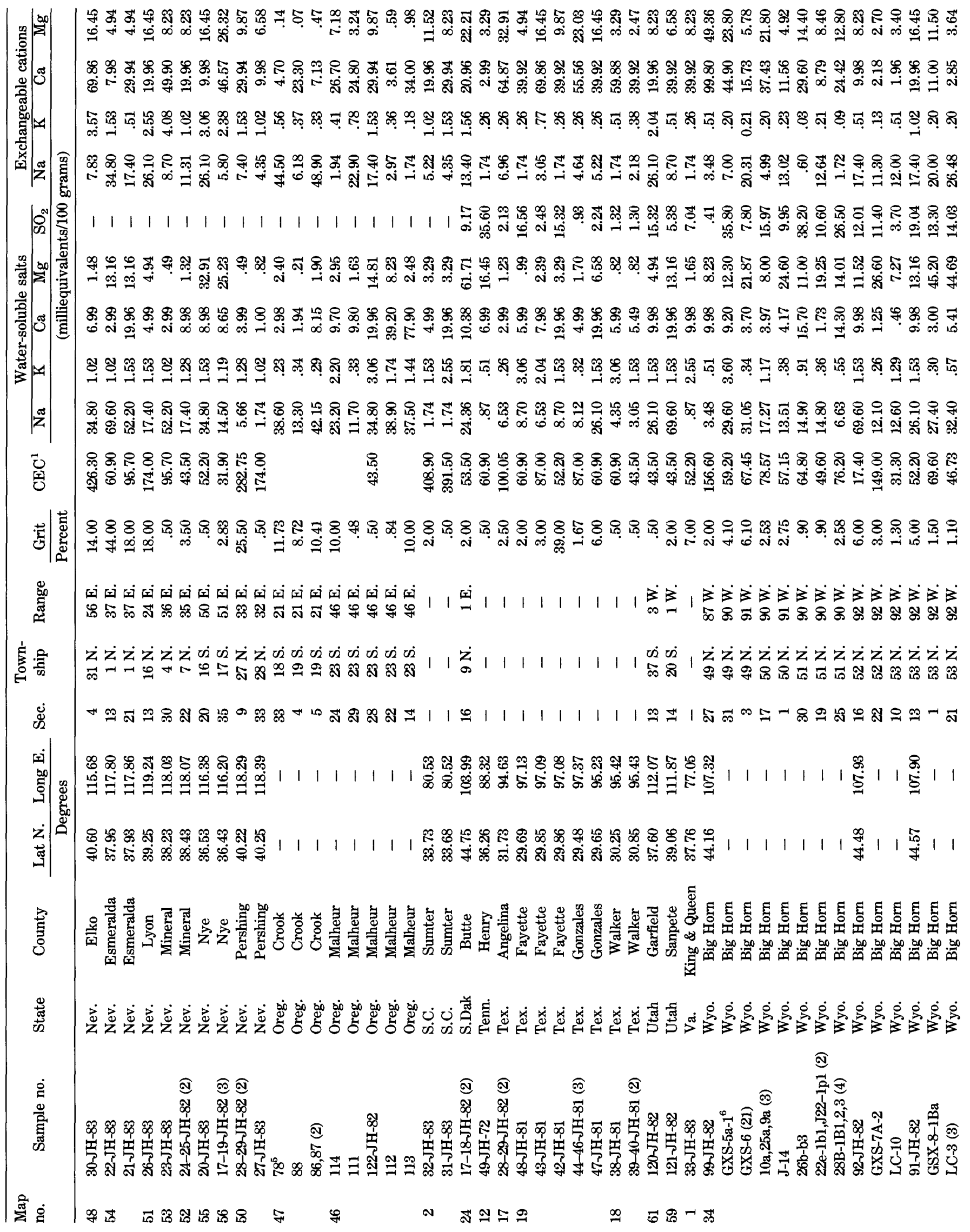




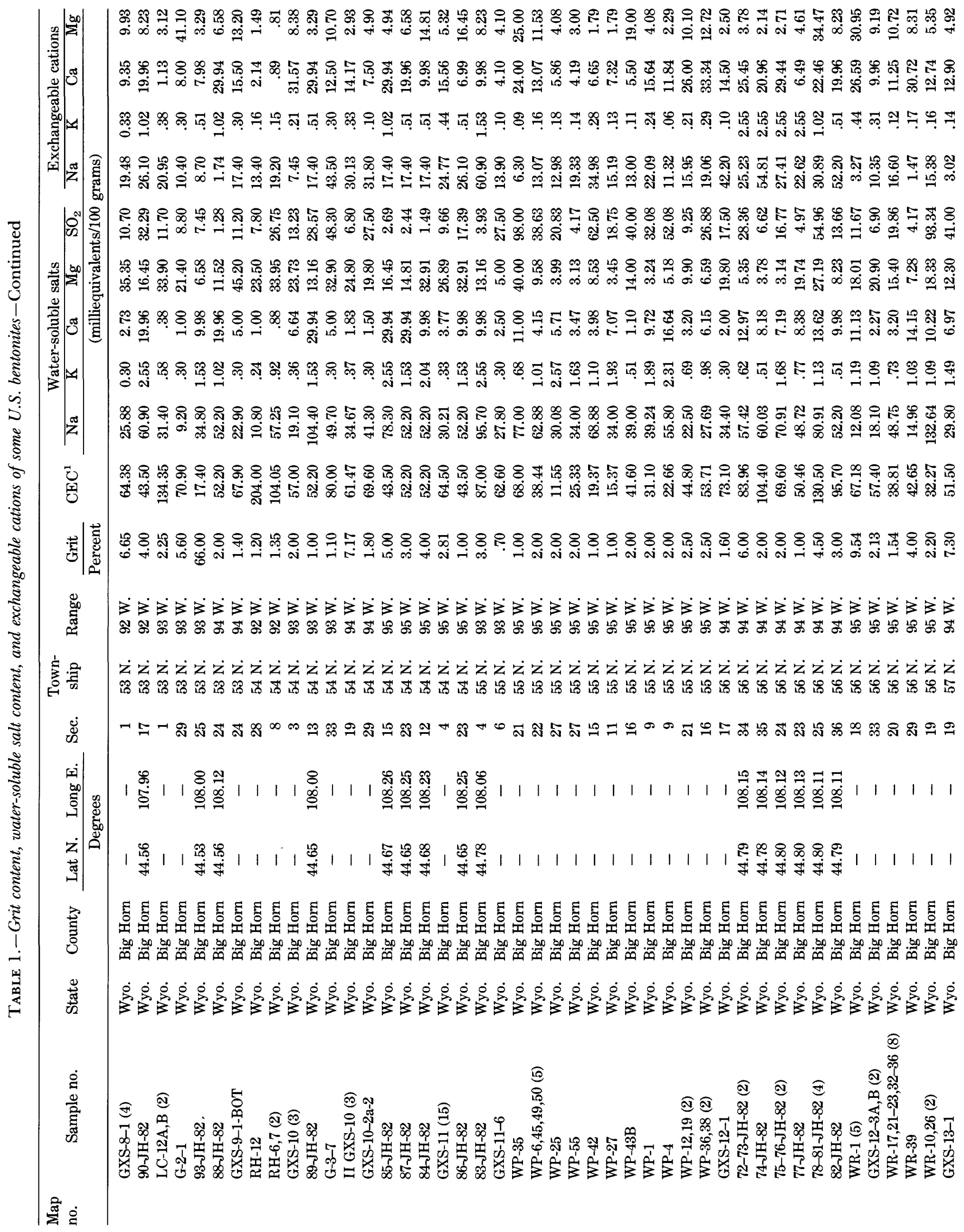




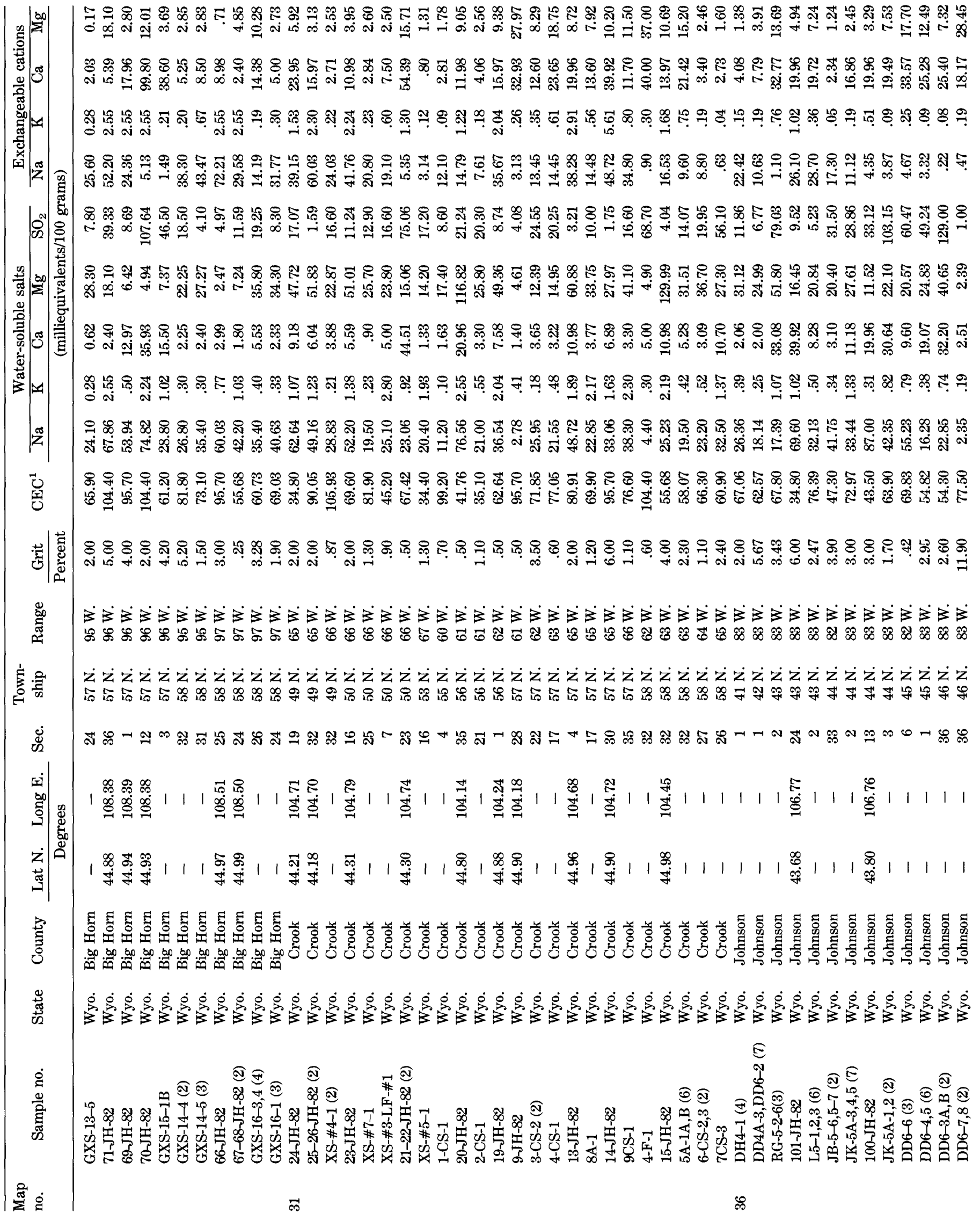




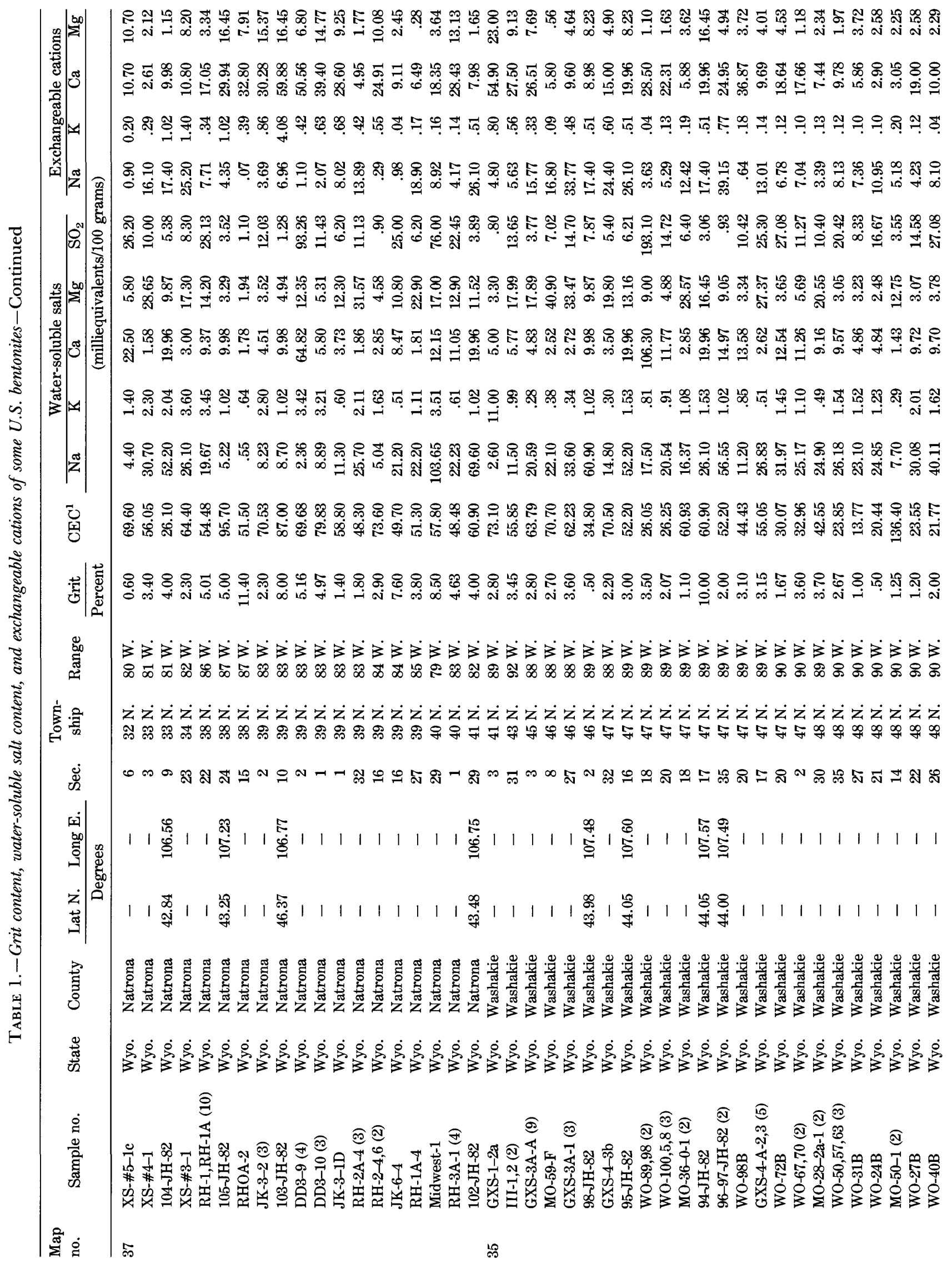




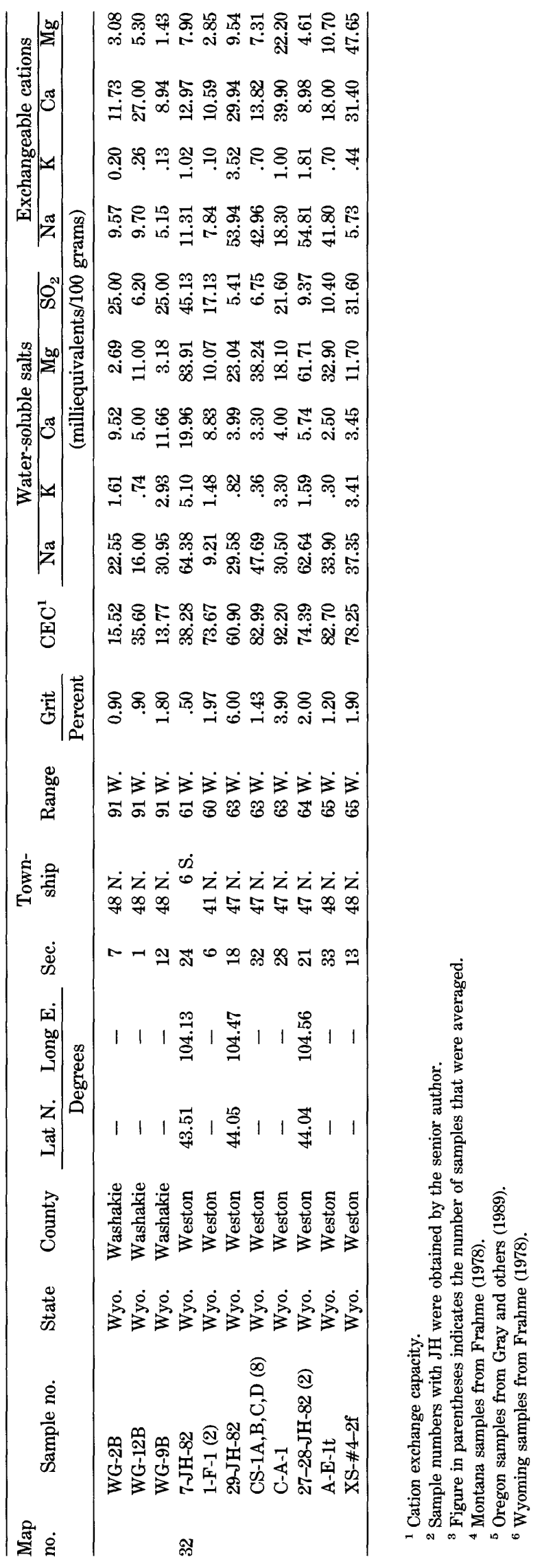




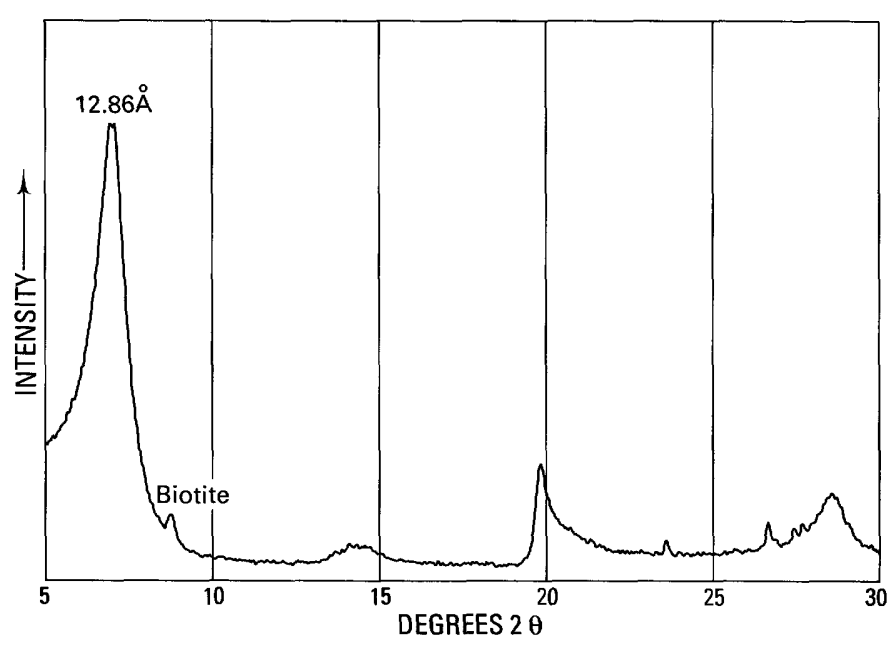

FIGURE 5. - X-ray diffraction trace of magnesium-bentonite (saponite) from Pleistocene tuffaceous playa beds, Nye County, Nev.

Fersman (1913) was the first to describe palygorskite from samples obtained from the Palygorsk Range on the Popovka River, U.S.S.R. The name attapulgite was first applied to the same mineral by Lapparent $(1935,1936)$ for its occurrence in the fuller's earth deposits near Attapulgus, Ga. The Clay Minerals Society Nomenclature Committee (Clays and Clay Minerals, 1971, p. 131) recommended that palygorskite and attapulgite be considered synonymous and that palygorskite has priority because it is the older name. The U.S. Bureau of Mines, however, continues to use attapulgite in their yearly U.S. production figures for fuller's earth, and the two terms, palygorskite and attapulgite, are therefore used interchangeably in this report.

Palygorskite is a complex magnesium silicate whose structure is based on silicate chains parallel to the $c$ axis

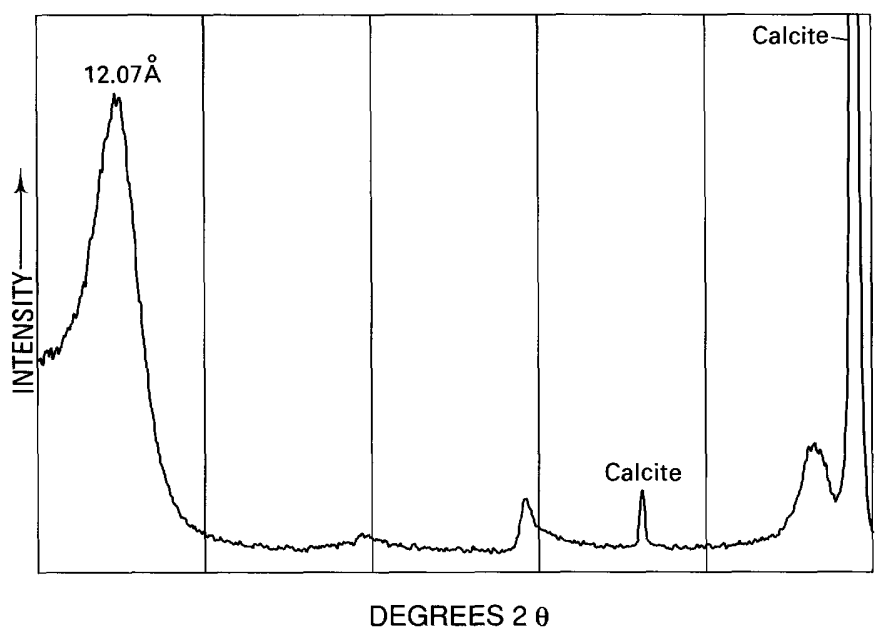

FIGURE 6.-X-ray diffraction trace of lithium-bentonite (hectorite) from the Hector deposit, San Bernardino County, Calif. similar to amphibole chains. The chains are arranged to form regular hexagonal rings in a plane perpendicular to the $c$ axis (Bradley, 1940). Four molecules of water per unit cell fill the interstices between the chains, which makes the clay mineral highly absorbent and very light in weight when dry. The theoretical formula is considered to be:

$$
\left(\mathrm{OH}_{2}\right)_{4}(\mathrm{OH})_{2} \mathrm{Mg}_{5} \mathrm{Si}_{8} \mathrm{O}_{20} \cdot 4 \mathrm{H}_{2} \mathrm{O}
$$

in which trivalent cations ( $\mathrm{Al}$ and $\mathrm{Fe}$ ) can substitute for $1.5 \mathrm{Mg}^{++}$(Bradley, 1940, p. 406). Palygorskite is recognized on the $\mathrm{X}$-ray diffraction traces by its very strong (011) peak at about 10.4-10.5 $\AA$. This spacing does not change with variations in relative humidity or moderate heating to about $300{ }^{\circ} \mathrm{C}$ (Grim, 1968, p. 154).

The U.S. Geological Survey has prepared a bentonite (CSB-1) and a palygorskite (ATT-1) as reference samples (Hosterman and Flanagan, 1987). The bentonite sample is from a clay pit in Crook County, Wyo., $26 \mathrm{~km}$ northwest of Belle Fourche, S. Dak. The palygorskite sample is from a pit in Gadsden County, Fla., $10 \mathrm{~km}$ south of Attapulgus Ga. Table 2 lists the chemical composition, and figure 7 and tables 3 and 4 give the mineralogical composition based on X-ray diffraction analysis of the two reference samples.

The nonclay fuller's earths, which are not included in this report, include opal claystone, residually weathered peridotite, and diatomite. The opal claystone, which is an uncommon rock type, composed of more than 75 percent opal, cristabolite, or other forms of poorly crystalline silica (Heron and others, 1965), was mined during the first part of this century in South Carolina, Virginia, and Maryland (Knechtel and Hosterman, 1965). A weathered peridotite, in Woodson County, Kans., is used for filler in animal feed (Price and Brady, 1981). Diatomite or diatomacous earth is a light-colored soft friable siliceous sedimentary rock consisting of opaline silica remains of diatoms, which are one-celled plants. Diatomite from Santa Barbara County, Calif. (Cleveland 1966, p.151), is used as a fuller's earth, to some extent.

\section{OCCURRENGES}

Although bentonite deposits of Triassic and Jurassic age exist in the western part of the United States, virtually all of the deposits mined to date (table 5 and pl. 1) are of Cretaceous age or younger. All of the bentonite that has been mined in South Dakota, Wyoming, and Montana, the principal source of sodium-bentonite in the United States, is from beds of Cretaceous age. Figure 8 shows the principal bentonite beds of Cretaceous age in Montana and Wyoming. The calcium-bentonite produced in Alabama and Mississippi also occurs in beds of Cretaceous age. The calcium-bentonite deposits in western 
TABLE 2.-Chemical analysis of oxides and trace elements in reference samples bentonite (CSB-1) and palygorskite (ATT-1). Modified from Hosterman and Flanagan (1987, table 4) [Oxides in percent; elements in parts per million]

\begin{tabular}{|c|c|c|}
\hline & CBS-1 & ATT-1 \\
\hline$\ldots \ldots \ldots \ldots \ldots \ldots \ldots$ & 55.3 & 59.6 \\
\hline $\mathrm{Al}_{2} \mathrm{O}_{3} \ldots \ldots \ldots \ldots \ldots \ldots \ldots \ldots$ & 21.8 & 9.50 \\
\hline $\mathrm{Fe}_{2} \mathrm{O}_{3} \ldots \ldots \ldots \ldots \ldots \ldots \ldots$ & 3.91 & 3.35 \\
\hline $\mathrm{MgO} \ldots \ldots \ldots \ldots \ldots \ldots \ldots$ & 1.94 & 9.14 \\
\hline $\mathrm{CaO} \ldots \ldots \ldots \ldots \ldots \ldots \ldots \ldots$ & 1.28 & 1.87 \\
\hline $\mathrm{Na}_{2} \mathrm{O} \ldots \ldots \ldots \ldots \ldots \ldots \ldots$ & 2.26 & .10 \\
\hline $\mathrm{K}_{2} \mathrm{O} \ldots \ldots \ldots \ldots \ldots \ldots \ldots$ & .54 & .86 \\
\hline $\mathrm{TiO}_{2} \ldots \ldots \ldots \ldots \ldots \ldots \ldots$ & .16 & .49 \\
\hline $\mathrm{P}_{2} \mathrm{O}_{5} \ldots \ldots \ldots \ldots \ldots \ldots \ldots$ & $<.05$ & .76 \\
\hline MnO $\ldots \ldots \ldots \ldots \ldots \ldots \ldots$ & .02 & .025 \\
\hline $\mathrm{Ag} \ldots \ldots \ldots \ldots \ldots \ldots \ldots \ldots$ & .202 & .135 \\
\hline B $\ldots \ldots \ldots \ldots \ldots \ldots \ldots \ldots \ldots \ldots$ & 46 & 12 \\
\hline $\mathrm{Ba} \ldots \ldots \ldots \ldots \ldots \ldots \ldots \ldots$ & 350 & 156 \\
\hline Be $\ldots \ldots \ldots \ldots \ldots \ldots \ldots \ldots \ldots$ & 1 & 1.32 \\
\hline Co $\ldots \ldots \ldots \ldots \ldots \ldots \ldots \ldots$. & .73 & 4.6 \\
\hline Cr...................... & 20 & 166 \\
\hline Cs...................... & .17 & 2.90 \\
\hline $\mathrm{Cu} \ldots \ldots \ldots \ldots \ldots \ldots \ldots \ldots$ & 5 & 9 \\
\hline $\mathrm{Ga} \ldots \ldots \ldots \ldots \ldots \ldots \ldots \ldots$ & 32 & 7.02 \\
\hline Hf....................... & 8.7 & 5.37 \\
\hline $\mathrm{Hg} \ldots \ldots \ldots \ldots \ldots \ldots \ldots \ldots$ & .020 & .082 \\
\hline Li...................... & 17 & 26.5 \\
\hline Mn $\ldots \ldots \ldots \ldots \ldots \ldots \ldots \ldots \ldots$ & 160 & 145 \\
\hline Mo $\ldots \ldots \ldots \ldots \ldots \ldots \ldots \ldots$ & 3.6 & 2.78 \\
\hline $\mathrm{Nb} \ldots \ldots \ldots \ldots \ldots \ldots \ldots \ldots \ldots$ & 18 & 9 \\
\hline $\mathrm{Ni} . \ldots \ldots \ldots \ldots \ldots \ldots \ldots \ldots$ & 9 & 28 \\
\hline$\ldots \ldots \ldots+\cdots \cdots \cdots \cdots$, & 54 & 18 \\
\hline$\ldots \ldots \ldots \ldots \ldots \ldots \ldots \ldots$ & 14 & 51 \\
\hline $\mathrm{Sb} . \ldots \ldots \ldots \ldots \ldots \ldots \ldots \ldots \ldots \ldots$ & 2.8 & 2.91 \\
\hline Sn....................... & 17 & 5.6 \\
\hline $\mathrm{Sr} \ldots \ldots \ldots \ldots \ldots \ldots \ldots \ldots \ldots$ & 246 & $\approx 110$ \\
\hline Та..................... & 4.37 & .70 \\
\hline $\mathrm{Th} \ldots \ldots \ldots \ldots \ldots \ldots \ldots \ldots \ldots$ & 50.6 & 7.49 \\
\hline $\mathrm{U} \ldots \ldots \ldots \ldots \ldots \ldots \ldots \ldots \ldots$ & 16.5 & 4.64 \\
\hline$\ldots \ldots \ldots \ldots \ldots \ldots \ldots \ldots \ldots$ & 5.3 & 70 \\
\hline $\mathrm{Y} \ldots \ldots \ldots \ldots \ldots \ldots \ldots \ldots \ldots$ & 34 & $\approx 25$ \\
\hline $\mathrm{Zn} \ldots \ldots \ldots \ldots \ldots \ldots \ldots \ldots$ & 90 & 86 \\
\hline Zr.................... & 150 & 210 \\
\hline Sc..................... & 4.6 & 6.0 \\
\hline La $\ldots \ldots \ldots \ldots \ldots \ldots \ldots \ldots$ & 58 & 21 \\
\hline $\mathrm{Ce} \ldots \ldots \ldots \ldots \ldots \ldots \ldots \ldots$ & 122 & 40 \\
\hline Nd $\ldots \ldots \ldots \ldots \ldots \ldots \ldots \ldots$ & 53.3 & 24 \\
\hline $\operatorname{Sm} \ldots \ldots \ldots \ldots \ldots \ldots \ldots \ldots$ & 13.1 & 4.62 \\
\hline $\mathrm{Eu} \ldots \ldots \ldots \ldots \ldots \ldots \ldots \ldots \ldots$ & .73 & .86 \\
\hline $\mathrm{Gd} \ldots \ldots \ldots \ldots \ldots \ldots \ldots \ldots$ & 11.3 & 4.48 \\
\hline $\mathrm{Tb} \ldots \ldots \ldots \ldots \ldots \ldots \ldots \ldots$ & 1.34 & .63 \\
\hline $\operatorname{Tm} \ldots \ldots \ldots \ldots \ldots \ldots \ldots \ldots$ & .74 & .43 \\
\hline $\mathrm{Yb} \ldots \ldots \ldots \ldots \ldots \ldots \ldots \ldots \ldots$ & 4.10 & 2.13 \\
\hline $\mathrm{Lu} \ldots \ldots \ldots \ldots \ldots \ldots \ldots \ldots \ldots$ & .59 & .35 \\
\hline
\end{tabular}

Oklahoma and eastern Arizona occur in beds of Paleocene age. The calcium-bentonite deposits, scattered throughout Nevada, Idaho, Oregon, and California, occur in beds of late Tertiary, Pleistocene, and Holocene age. The low-grade bentonitic clay deposits of the East Coast occur in beds of Paleocene age in South Carolina and

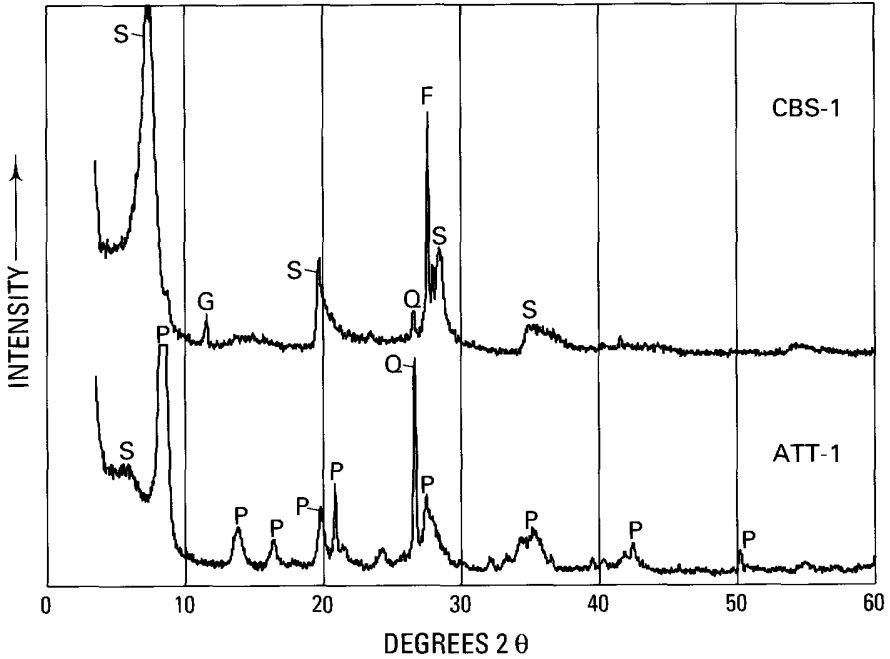

FIGURE 7. - X-ray diffraction traces of bentonite (CSB-1) from Crook County, Wyo., and palygorskite (ATT-1) from Gadsden County, Fla. $\mathrm{G}=$ gypsum, $\mathbf{F}=$ feldspar (plagioclase), $\mathrm{S}=$ smectite (montmorillonite), $\mathrm{Q}=$ quartz, $\mathrm{P}=$ palygorskite (attapulgite).

Miocene age in Virginia. The palygorskite-type fuller's earth deposits of Florida and Georgia are in beds of Miocene age. The calcium-bentonite-type fuller's earth of the Paleocene age Porters Creek Clay occurs in Georgia, Alabama, Mississippi, Tennessee, Kentucky, Illinois, and Missouri (fig. 9). Beds of calcium-bentonite of Eocene and Miocene age are found in Georgia, Louisiana, and Texas. Figure 10 shows the Cretaceous and Tertiary geologic units of Texas, Louisiana, Arkansas, Kentucky, Tennessee, Mississippi, Alabama, and Georgia that contain economic and potentially economic bentonite and attapulgite.

Most bentonite and fuller's earth deposits are in beds or lenses within definite stratigraphic zones. Some deposits are in beds that extend for more than $322 \mathrm{~km}$;

TABLE 3. - X-ray diffraction data for bentonite CSB-1 [Do., ditto; d, d-spacing in angstroms; I, relative intensity]

\begin{tabular}{|c|c|c|c|}
\hline Degrees $2 \theta$ & $d$ & I & Mineral \\
\hline 6.66 . & 13.260 & 100 & Montmorillonite. \\
\hline$\ldots \ldots \ldots \cdots$ & 10.226 & 2 & Biotite. \\
\hline 11.56 . & 7.648 & 10 & Gypsum. \\
\hline 13.62 . & 6.496 & 1 & Plagioclase. \\
\hline$\ldots \ldots \ldots \ldots$, & 6.197 & 3 & Montmorillonite. \\
\hline $19.74 \ldots \ldots \ldots \ldots \ldots$ & 4.494 & 30 & Do. \\
\hline $20.80 \ldots \ldots \ldots \ldots \ldots$ & 4.267 & 2 & Quartz. \\
\hline $23.54 \ldots \ldots \ldots \ldots \ldots$ & 3.776 & 5 & Montmorillonite. \\
\hline $26.64 \ldots \ldots \ldots \ldots \ldots$ & 3.343 & 10 & Quartz. \\
\hline $27.64 \ldots$ & 3.225 & 30 & Plagioclase. \\
\hline$\ldots \ldots \ldots$ & 3.184 & 45 & Do. \\
\hline 28.60 . & 3.118 & 35 & Montmorillonite. \\
\hline 35.10 . & 2.554 & $10 \mathrm{~B}$ & Do. \\
\hline 54.44 . & 1.684 & $5 B$ & Do. \\
\hline
\end{tabular}


TABLE 4.-X-ray diffraction data for palygorskite ATT-1 [Do., ditto; d, d-spacing in angstroms; I, relative intensity]

\begin{tabular}{|c|c|c|c|}
\hline Degrees $2 \theta$ & $d$ & I & Mineral \\
\hline 6.08 & 14.531 & 2 & Montmorillonite. \\
\hline 8.39 & 10.526 & 100 & Palygorskite. \\
\hline$\ldots \ldots \ldots \ldots$ & 6.357 & 8 & Do. \\
\hline $16.41 \ldots \ldots \ldots \ldots \ldots$ & 5.390 & 7 & Do. \\
\hline$\ldots \ldots \ldots \ldots \ldots$ & 4.474 & 18 & Do. \\
\hline $20.83 \ldots \ldots \ldots \ldots \ldots$ & 4.261 & 10 & Quartz. \\
\hline $21.37 \ldots \ldots \ldots \ldots \ldots$ & 4.154 & 5 & Palygorskite. \\
\hline $24.18 \ldots \ldots \ldots \ldots \ldots$ & 3.678 & 5 & Do. \\
\hline $26.64 \ldots \ldots \ldots \ldots \ldots$ & 3.344 & 50 & Quartz. \\
\hline $27.48 \ldots \ldots \ldots \ldots \ldots$ & 3.243 & 11 & Palygorskite. \\
\hline $28.52 \ldots \ldots \ldots \ldots \ldots$ & 3.127 & 8 & Do. \\
\hline $31.95 \ldots \ldots \ldots \ldots \ldots$ & 2.799 & 5 & Do. \\
\hline $33.32 \ldots \ldots \ldots \ldots \ldots$ & 2.687 & 5 & Do. \\
\hline $34.43 \ldots \ldots \ldots \ldots \ldots$ & 2.602 & 10 & Do. \\
\hline $35.04 \ldots \ldots \ldots \ldots \ldots$ & 2.559 & 11 & Do. \\
\hline $36.51 \ldots \ldots \ldots \ldots \ldots$ & 2.459 & 4 & Do. \\
\hline $39.51 \ldots \ldots \ldots \ldots \ldots$ & 2.279 & 5 & Quartz. \\
\hline $40.33 \ldots \ldots \ldots \ldots \ldots$ & 2.234 & 5 & Do. \\
\hline $42.41 \ldots \ldots \ldots \ldots \ldots$ & 2.129 & 8 & Do. \\
\hline $50.14 \ldots \ldots \ldots \ldots \ldots$ & 1.818 & 6 & Do. \\
\hline $54.87 \ldots \ldots \ldots \ldots \ldots$ & 1.672 & 4 & Do. \\
\hline
\end{tabular}

other deposits are in lenses that are a few hundred meters in diameter (Patterson and Murray, 1975, p. 531). Deposits that are mined range from $0.3 \mathrm{~m}$ to more than $10 \mathrm{~m}$ in thickness. The maximum overburden-to-clay ratio is generally about 10:1, but in places more than 30 $m$ of overburden is removed to expose a 1-m-thick bentonite layer. The bedded deposits commonly have a sharp contact with the underlying rocks and a gradational contact with the overlying ones. Bentonite deposits formed by hydrothermal processes tend to be very irregular in shape, their vertical dimension is commonly greater than their horizontal dimensions, and they grade into the host rock in all directions. The floor of a bentonite bed is commonly silicified at the top with silica that has been leached from the bentonite and redeposited (Knechtel and Patterson, 1962). The typical weathered outcrop of the high-swelling sodium-bentonite has a popcornlike appearance caused by the alternating swelling and drying of the bentonite. Weathered outcrops of the low-swelling calcium-bentonite frequently have a cracked appearance that resembles alligator hide.

\section{DESCRIPTION OF DEPOSITS}

\section{ALABAMA}

Alabama produces nearly $200,000 \mathrm{t}$ of bentonite annually but no fuller's earth. Known reserves are sufficient to support at least $20 \mathrm{yr}$ of bentonite mining at the current rate of production, indicating that the bentonite

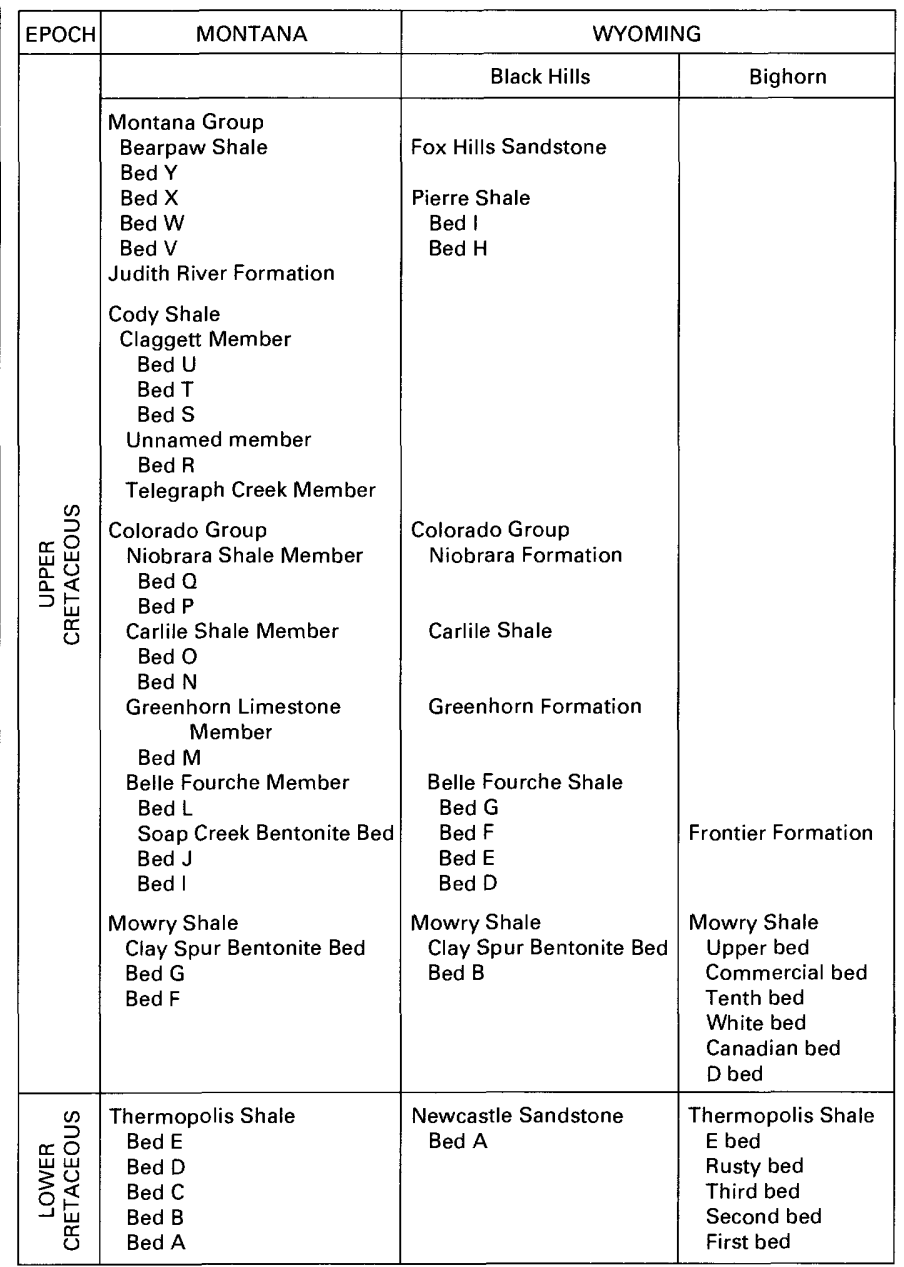

FIGURE 8.-Geologic formations and bentonite beds of the Montana and Wyoming bentonite districts. Modified from Knechtel and Patterson $(1956,1962)$ and NL Baroid (written commun., August 1982).

resources in Alabama are more than $4 \mathrm{Mt}$. At least 100 Mt of low-grade fuller's earth is known to exist in the Porters Creek Clay of the Midway Group.

\section{SANDY RIDGE DEPOSIT}

Bentonite occurs near the base of the Ripley Formation of the Selma Group (Hosterman, 1984, p. C4) of Cretaceous age, at Sandy Ridge in southeastern Lowndes County and extending into Montgomery County to the east (no. 8, pl. 1). The area is within the Gulf of Mexico Coastal Plain. The best grade bentonite contains some sand, less than 10 percent silt, and more than 90 percent clay-size material (table 1 , map no. 8) (Hosterman, 1984, p. C17). The clay is composed of as much as 95 percent calcium montmorillonite (Clarke, 1970 , p. 17). The clay bed is dark gray, weathers to yellowish brown, and ranges in thickness from $30 \mathrm{~cm}$ to $4.5 \mathrm{~m}$ (Beg and others, 1986, p. 6). The bentonite is being 
TABLE 5.-Active and inactive bentonite and fuller's earth deposits and districts [do and Do., ditto]

\begin{tabular}{|c|c|c|c|c|c|}
\hline $\begin{array}{l}\text { State } \\
\text { and } \\
\text { map no. }\end{array}$ & $\begin{array}{l}\text { Deposit } \\
\text { or town }\end{array}$ & County & Geologic unit & Age & Product \\
\hline \multicolumn{6}{|c|}{ ALABAMA } \\
\hline 8 & Sandy Ridge & Lowndes & Ripley Formation & Cretaceous & Bentonite. \\
\hline 9 & & Sumter & Porters Creek Clay & Paleocene & Bentonite fuller's earth. \\
\hline \multicolumn{6}{|c|}{ ARIZONA } \\
\hline $62 a$ & Cheto & Apache & Bidahochi Formation & Miocene and Pliocene & Bentonite. \\
\hline 63 & Camp Verde & Yavapai & Verde Formation & do. & Do. \\
\hline 64 & Lyles & do. & lake beds & Holocene (?) & Hectorite (?). \\
\hline 65 & Burro Creek & Mohave & do. & & Saponite (?). \\
\hline 66 & Bouse & Yuma & do. & & Hectorite (?). \\
\hline \multicolumn{6}{|c|}{ CALIFORNIA } \\
\hline 67 & Hector & San Bernardino & Red Mountain andesite & Pliocene & Hectorite. \\
\hline 68 & Pacific & do. & unknown & Tertiary & Bentonite. \\
\hline 69 & Cajon & do. & do. & Miocene & Do. \\
\hline 70 & Otay & San Diego & Otay Member & do. & Do. \\
\hline 80 & Vallecitos & San Benito & Kreyenhagen Formation & Eocene and Ogliocene & Do. \\
\hline 71 & Amargo & Kern & Tropico Group (?) & Oligocene and Miocene & Do. \\
\hline 73 & Tehachapi & do. & Kinnick Formation & Miocene & Do. \\
\hline 72 & Muroc & do. & Tropico Group & $\begin{array}{l}\text { Oligocene and } \\
\text { Miocene. }\end{array}$ & Do. \\
\hline 76 & McKittrick & do. & unknown & Holocene & Do. \\
\hline 75 & Iron Canyon & do. & Ricardo Formation & Miocene and Pliocene & Do. \\
\hline 74 & Snow White & do. & do. & do. & Do \\
\hline 79 & Olancha & Inyo & volcanic tuff & Tertiary (?) & Bentonite fuller's earth. \\
\hline 77 & Shoshone & do. & lake beds & Pleistocene & Bentonite. \\
\hline 78 & Tecopa & do. & do. & do. & Saponite (?). \\
\hline \multicolumn{6}{|c|}{ COLORADO } \\
\hline 39 & La Junta & Bent & Morrison Formation & Jurassic & Bentonite. \\
\hline 41 & Grand Junction & Mesa & do. & do. & Do. \\
\hline 40 & Salida & Fremont & welded tuff & Tertiary & Do. \\
\hline 38 & Sterling & Weld & White River Formation & Oligocene & Do. \\
\hline \multicolumn{6}{|c|}{ FLORIDA } \\
\hline 7 & Lowell & Marion & Hawthorn Group & Miocene and Pliocene & Bentonite fuller's earth. \\
\hline $5 \mathrm{~d}$ & Quincy & Gadsden & do. & do. & Do. \\
\hline \multicolumn{6}{|c|}{ GEORGIA } \\
\hline $5 c$ & Attapulgus & Decatur & Hawthorn Group & Miocene & Attapulgite fuller's earth. \\
\hline $5 c$ & do. & do. & do. & do. & Bentonite fuller's earth. \\
\hline $5 b$ & Ochlocknee & Thomas & do. & do. & Do. \\
\hline $5 b$ & do. & do. & do. & do. & Do. \\
\hline $5 \mathrm{a}$ & Meigs & do. & do. & do. & Do. \\
\hline $5 a$ & do. & do. & do. & do. & Do. \\
\hline 3 & Wrens & Jefferson & Twiggs Clay Member & Eocene & Do. \\
\hline 4 & Pikes Peak & Twiggs & Barnwell Group & do. & Do. \\
\hline 6 & Troutman & Stewart & Porters Creek Clay & Paleocene & Do \\
\hline \multicolumn{6}{|l|}{ IDAHO } \\
\hline 45 & Grandview & Owyhee & volcanic tuff & & Bentonite. \\
\hline 43 & Salmon & Lemhi & tuffaceous rocks & Miocene & Do. \\
\hline 44 & Lidy Hot Springs & Clark & & do. & Bentonite (?). \\
\hline \multicolumn{6}{|c|}{ ILLINOIS } \\
\hline 13 & Olmsted & Pulaski & Porters Creek Clay & Paleocene & Bentonite fuller's earth. \\
\hline 13 & do. & do. & do. & do. & Do. \\
\hline \multicolumn{6}{|c|}{ KANSAS } \\
\hline 21 & & Phillips & Pierre Shale & Cretaceous & Bentonite. \\
\hline 22 & & Wallace & Ogallala Formation & Pliocene & Do. \\
\hline \multicolumn{6}{|c|}{ LOUISIANA } \\
\hline 16 & Hornbeck & Vernon & Fleming Formation & Miocene & Bentonite. \\
\hline 15 & Bogalusa & Washington & Catahoula Formation & do. & Do. \\
\hline
\end{tabular}


TABLE 5.-Active and inactive bentonite and fuller's earth deposits and districts-Continued

\begin{tabular}{|c|c|c|c|c|c|}
\hline $\begin{array}{l}\text { State } \\
\text { and } \\
\text { map no. }\end{array}$ & $\begin{array}{l}\text { Deposit } \\
\text { or town }\end{array}$ & County & Geologic unit & Age & Product \\
\hline \multicolumn{6}{|c|}{ MISSISSIPPI } \\
\hline 10 & Aberdeen & Monroe & Eutaw Formation & Cretaceous & Bentonite. \\
\hline 10 & do. & do. & do. & do. & Do. \\
\hline 11 & Ripley & Tippah & Porters Creek Clay & Paleocene & Bentonite fuller's earth. \\
\hline 11 & Blue Mountain & do. & do. & do. & Do. \\
\hline \multicolumn{6}{|c|}{ MISSOURI } \\
\hline 14 & Oran & Stoddard & Porters Creek Clay & Paleocene & Bentonite fuller's earth. \\
\hline \multicolumn{6}{|c|}{ MONTANA } \\
\hline 29 & Wyotana Siding & Big Horn & Mowry and Belle Fourche Shale & Cretaceous & Bentonite. \\
\hline 25 & Alzada & Carter & do. & do. & Do. \\
\hline 30 & Warren & Carbon & Thermopolis Shale & do. & Do. \\
\hline 27 & Malta & Phillips & Bearpaw Shale & do. & Do. \\
\hline 26 & Glasgow & Valley & do. & do. & Do. \\
\hline 28 & Vananda & Treasure & do. & do. & Do. \\
\hline \multicolumn{6}{|c|}{ NEVADA } \\
\hline 56 & Ash Meadows & Nye & playa sediments & Pleistocene & Bentonite. \\
\hline 55 & Beatty & Nye & altered tuff & Miocene and Pliocene & Bentonite (hydrothermal). \\
\hline 54 & Blanco & Esmeralda & Esmeralda Formation & do. & Do. \\
\hline 50 & Bluff & Pershing & volcanic tuffs & Oligocene & Do. \\
\hline 49 & Rosebud Canyon & do. & lacustrine sediments & Miocene and Pliocene & Bentonite. \\
\hline 51 & Jupiter & Lyon & andesite & do. & Bentonite (hydrothermal). \\
\hline 52 & Walker Lake & Mineral & Esmeralda Formation & do. & Bentonite. \\
\hline 53 & Sodaville & do. & volcanic tuffs & do. & Bentonite (hydrothermal). \\
\hline $48 \mathrm{a}$ & McDermitt Hectorite & Humboldt & Volcanogenic sediments & Miocene & Hectorite. \\
\hline $48 \mathrm{~b}$ & Huntington Creek & Elko & Humboldt Formation & do. & Bentonite. \\
\hline 58 & Castle Mountain & Clark & volcanic rocks & Tertiary & Do. \\
\hline 57 & Vanderbilt & do. & Gale Hills Formation & Cretaceous and Tertiary(?) & Do. \\
\hline \multicolumn{6}{|c|}{ NEW MEXICO } \\
\hline $62 \mathrm{~b}$ & Gallup & McKinley & Bidahochi Formation & Pliocene & Bentonite plant. \\
\hline 42 & Hatch & Dona Ana & Santa Fe Group & Miocene to Pleistocene & Bentonite. \\
\hline \multicolumn{6}{|c|}{ OKLAHOMA } \\
\hline 20 & Vici & Dewey & Ogallala Formation & Miocene & Bentonite fuller's earth. \\
\hline \multicolumn{6}{|c|}{ OREGON } \\
\hline 46 & Adrian & Malheur & Sucker Creek Formation & Miocene & Bentonite. \\
\hline 47 & Brothers & Crook & John Day Formation & Eocene to Miocene & Bentonite fuller's earth. \\
\hline \multicolumn{6}{|c|}{ SOUTH CAROLINA } \\
\hline 2 & Rimini & Sumter & Black Mingo Formation & Paleocene & Bentonite fuller's earth. \\
\hline \multicolumn{6}{|c|}{ SOUTH DAKOTA } \\
\hline 24 & Belle Fourche & Butte & Mowry Shale & Cretaceous & Bentonite. \\
\hline 23 & Ardmore & Fall River & Pierre Shale & do. & Bentonite. \\
\hline \multicolumn{6}{|c|}{ TENNESSEE } \\
\hline 12 & Paris & Henry & Porters Creek Clay & Paleocene & Bentonite fuller's earth. \\
\hline \multicolumn{6}{|l|}{ TEXAS } \\
\hline 17 & Lufkin & Angelina & Yegua Fm. Claiborne Gr. & Eocene & Bentonite fuller's earth. \\
\hline 18 & Riverside & Walker & Catahoula Formation & Miocene & Bentonite. \\
\hline $19 \mathrm{a}$ & Muldoon & Fayette & Caddell Fm. Jackson Gr. & Eocene & Do. \\
\hline $19 \mathrm{~b}$ & Flatonia & do. & Manning Fm. Jackson Gr. & do. & Do. \\
\hline $19 \mathrm{c}$ & Waelder & Gonzales & Caddell Fm. Jackson Gr. & do. & Do. \\
\hline $19 \mathrm{~d}$ & Gonzales & do. & Yegua Fm. Claiborne Gr. & do. & Do. \\
\hline \multicolumn{6}{|l|}{ UTAH } \\
\hline 61 & Tropic & Garfield & Dakota Formation & Cretaceous & Bentonite. \\
\hline 59 & Richmond & Sanpete & Gray Gulch Formation & Oligocene & Do. \\
\hline 60 & Aurora & Sevier & Gray Gulch Formation(?) & do. & Do. \\
\hline \multicolumn{6}{|c|}{ VIRGINIA } \\
\hline 1 & Walkerton & King \& Queen & Calvert Formation & Miocene & Bentonite fuller's earth. \\
\hline \multicolumn{6}{|c|}{ WYOMING } \\
\hline 31 & Colony & Crook & Belle Fouche Shale & Cretaceous & Bentonite. \\
\hline 31 & & do. & Mowry Shale & do. & Do. \\
\hline 32 & Upton & Weston & do. & do. & Do. \\
\hline
\end{tabular}


TABLE 5.-Active and inactive bentonite and fuller's earth deposits and districts - Continued

\begin{tabular}{|c|c|c|c|c|c|}
\hline $\begin{array}{l}\text { State } \\
\text { and } \\
\text { map no. }\end{array}$ & $\begin{array}{l}\text { Deposit } \\
\text { or town }\end{array}$ & County & Geologic unit & Age & Product \\
\hline \multicolumn{6}{|c|}{ WYOMING-Continued } \\
\hline $34 a$ & Lovell & Big Horn & Mowry Shale & Cretaceous & Bentonite. \\
\hline $34 \mathrm{a}$ & do. & do. & do. & do. & Do. \\
\hline $34 a$ & do. & do. & do. & do. & Do. \\
\hline $34 \mathrm{~b}$ & Greybull & do. & do. & do. & Do. \\
\hline $34 \mathrm{~b}$ & do. & do. & do. & do. & Do. \\
\hline 35 & Worland & Washakie & do. & do. & Do. \\
\hline 37 & Casper & Natrona & Mowry Shale & do. & Do. \\
\hline 36 & Kaycee & Johnson & do. & do. & Do. \\
\hline 33 & Newcastle & Weston & Belle Fourche Shale & do. & Do. \\
\hline
\end{tabular}

mined by the American Colloid Company and is used chiefly as a binder for foundry sand in the automotive industry (Hosterman, 1985). The extent of the bentonite in Lowndes and Montgomery Counties indicates that many millions of metric tons are present.

\section{SUMTER COUNTY}

In western Alabama (fig. 9), the Porters Creek Clay, Midway Group of early Paleocene age, is divided into two members-an unnamed basal and the upper Matthews Landing Marl Member. The unnamed member is divided into two lithologic units, a lower unit of gray calcareous clay containing argillaceous limestone and an upper unit of very dark gray to black clay that is blocky and breaks with a conchoidal fracture. The dark-gray to black clay unit is 91-106 m thick in Sumter County, is about $40 \mathrm{~m}$ thick in Marengo County, and is not recognized in Wilcox County (Clarke, 1970, p. 19). In 1976, the dark-gray to black clay unit was used in making lightweight aggregate by the Tombigbee Lightweight Aggregate Corp. (Clarke and Tyrell, 1976). A sample of Porters Creek Clay, collected from a pit located $6 \mathrm{~km}$ northeast of York, Sumter County, west of highway U.S. 11 in $\mathrm{SW} 1 / 4 \mathrm{sec}$. 14, T. 18 N., R. 3 W. (no. 9, pl. 1), contained approximately 70 percent clay and 30 percent quartz silt and sand. The clay is composed of about 50 percent montmorillonite, 25 percent illite, and 25 percent kaolinite. The thickness of the dark-gray to black clay unit and its known extent in Sumter and Marengo Counties indicate a resource of many billion metric tons that are suitable for use as a lightweight aggregate and possibly several fuller's earth products.

\section{ARIZONA}

Commercial production of bentonite from the Cheto deposit began in 1924 when $27 \mathrm{t}$ of clay was shipped to New York for use in cosmetics (Wilson and Roseveare,
1949). Arizona currently produces about $25,000 \mathrm{t}$ of bentonite annually from the Cheto deposit. Bentonite production from the Cheto deposit reached a peak in 1957 at 245,000 t. The decline in the production of bentonite resulted from synthetic zeolites replacing activated clay as petroleum cracking catalysts. The total production of bentonite from the Cheto deposit is estimated to be 4-6 Mt (Eyde and Eyde, 1987, p. 47).

\section{CHETO DEPOSIT}

The Cheto bentonite deposit, Apache County, Ariz. is located about $6 \mathrm{~km}$ east of Sanders in northeastern Arizona and almost $60 \mathrm{~km}$ southwest of Gallup, N. Mex. (no. 62, pl. 1). The deposit is currently being mined by the Harshaw/Filtrol Partnership of Kaiser Aluminum \& Chemical Corp. and Chevron Corp. This deposit has been a source of high-purity bentonite since 1924 . The bentonite from this deposit has been used as a bleaching agent, as a petroleum catalyst, as a gelling agent, and as a desiccant. It is processed for use as a desiccant by one company at a plant located at Gallup, N. Mex., and it is processed for use as a catalyst by the United Catalyst, Inc., Louisville, Ky.

The bentonite (table 1, map no. 62), which consists of white calcium-montmorillonite that has low swelling properties, was formed by the alteration of a vitric quartz latite ash-flow tuff (Kiersch and Keller, 1955; Sloane and Guilbert, 1967). The bentonite occurs as flatlying beds in the lower member and in the lower part of the upper member of the Pliocene Bidahochi Formation (Eyde and Eyde, 1987; Eyde, 1989). Unaltered rhyolitic to basaltic ash-flow tuff beds occur in both members of the Bidahochi Formation. Apparently the chemical environment at the sedimentary basin sites of deposition and the latitic composition of the vitric volcanic ash were necessary for the alteration to bentonite.

According to Eyde and Eyde (1987), all of the bentonite mined, to date, from the Cheto deposit is from one 

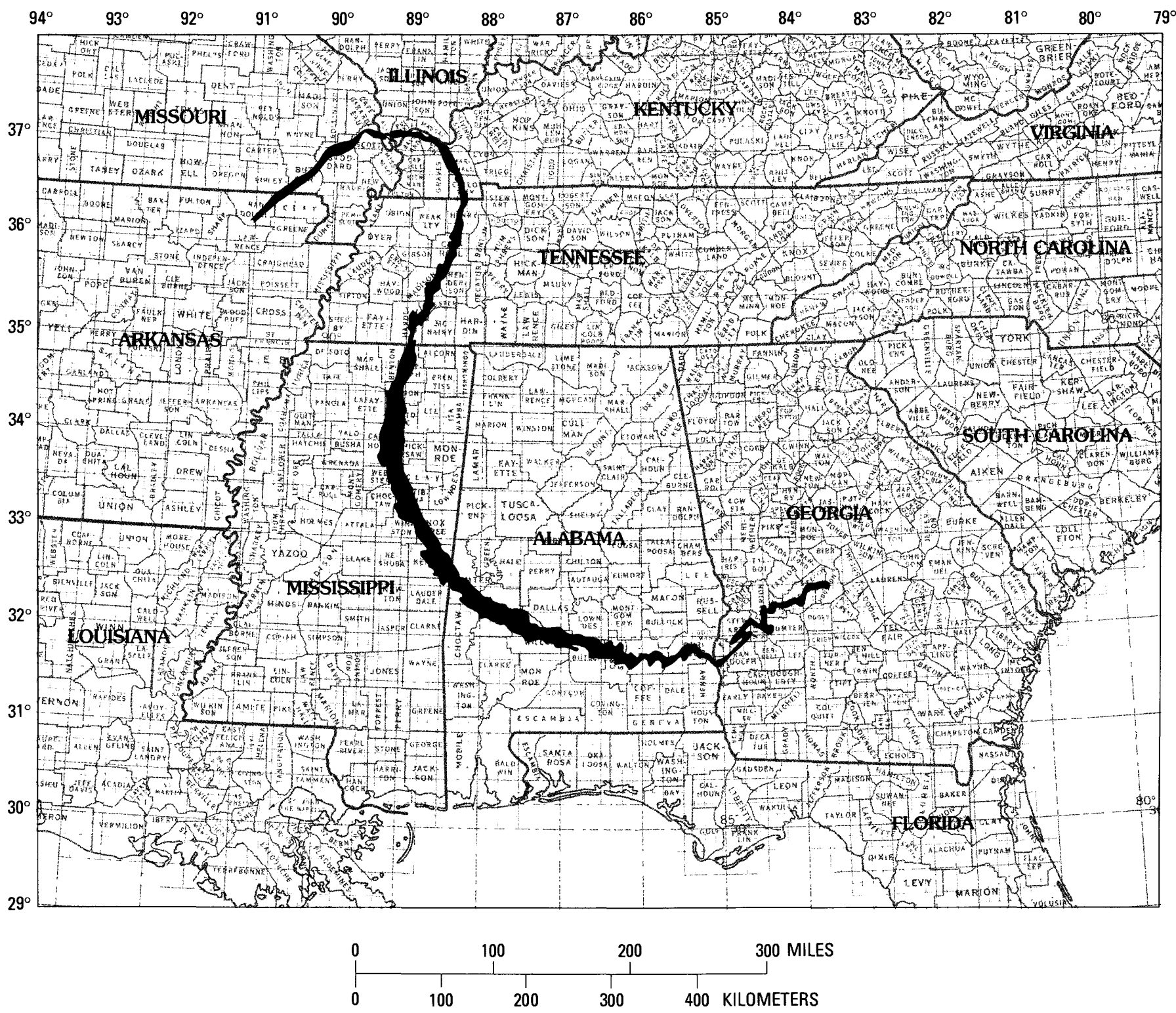

Figure 9. - Outcrop belt of the Porters Creek Clay (Formation) in Georgia, Alabama, Mississippi, Tennessee, Kentucky, Illinois, Missouri, and Arkansas. (Screened lines are county boundaries.)

bed that has an average thickness of about 1-1.2 $\mathrm{m}$ and an overburden of $23-38 \mathrm{~m}$. Locally the bed is overlain and underlain by light-reddish-brown to light-brown silt. The bentonite-silt contacts are usually sharp, but near the margins of the basin, the contacts are gradational, and the bentonite becomes intermixed with silt. A second bentonite bed about $10 \mathrm{~m}$ below the bed currently mined was recently discovered by drilling (Eyde, 1986, p. 154 ). This bed is about $1.8 \mathrm{~m}$ thick and appears to be similar mineralogically to the upper bed.

The recent discovery, at the Cheto deposit, of a bed below the bentonite bed currently mined (Eyde and
Eyde, 1987, p. 50) has doubled the potential resources of Arizona to greater than $2 \mathrm{Mt}$.

\section{OTHER DEPOSITS}

The Camp Verde deposit, located $6 \mathrm{~km}$ southeast of Camp Verde (no. 63, pl. 1), Yavapai County, is in the Verde Formation of Miocene and Pliocene age (Patterson, 1969 , p. 329). During the 1960 's, this bentonite was mined by the Arizona Gypsum Company and used for bonding iron ore and for sealing reservoirs, stock ponds, and irrigation ditches. Two samples from the abandoned pit were found to contain 95-99 percent clay (table 1, map no. 63). 

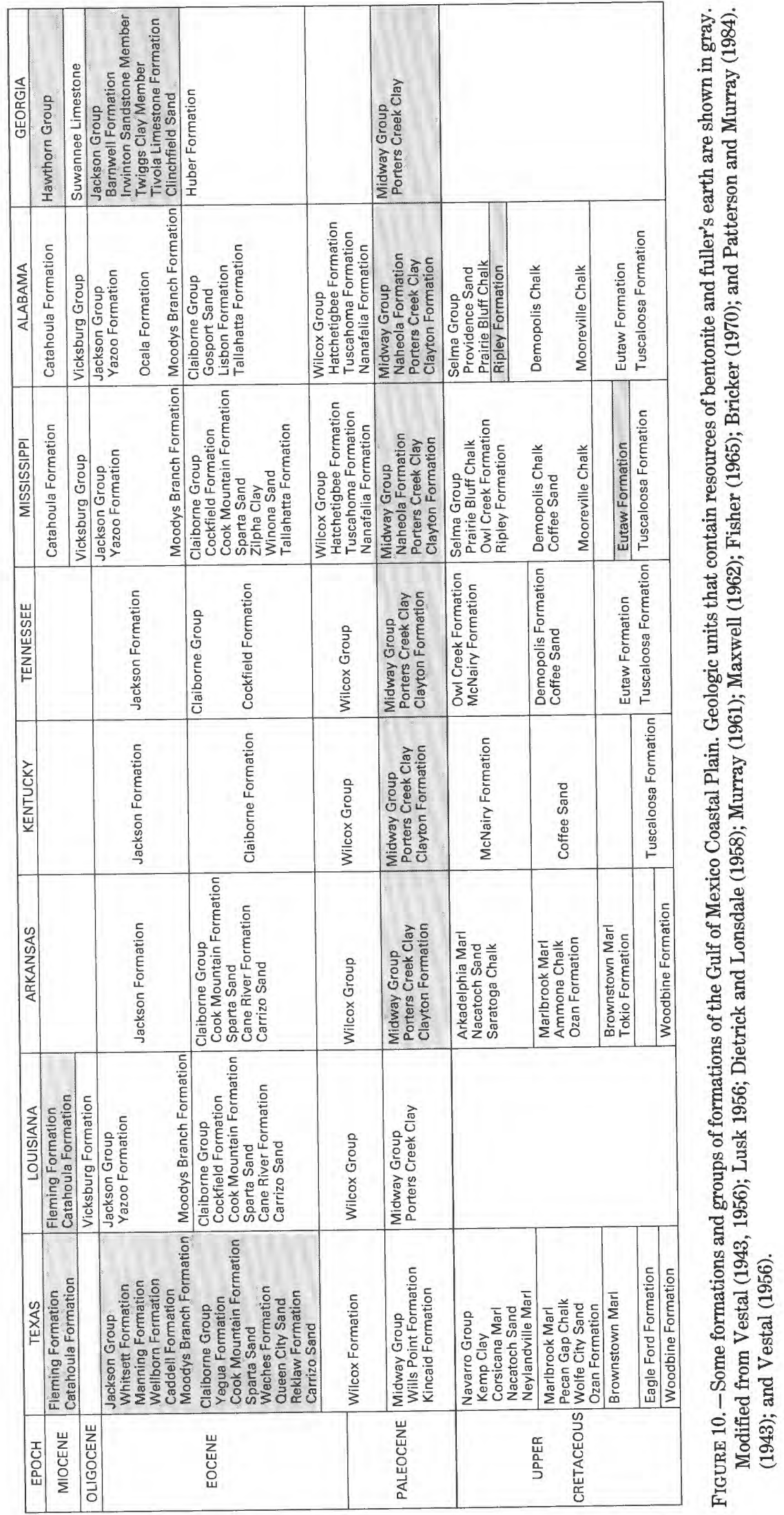
The Lyles deposit (no. 64, pl. 1) located $4.8 \mathrm{~km}$ east of Yava, Yavapai County, produced a small quantity of bentonite also used for sealing water impoundment areas. The deposit, which occurs in a lake bed of Quaternary(?) age, contains $0.3-0.5$ percent lithium oxide and may be related mineralogically and chemically to the lithium-rich hectorite in California (Norton, 1965). A sample from the Lyles pit had 87 percent clay and 13 percent sand and silt. X-ray diffraction traces show smectite (hectorite?) to be the only clay mineral associated with the nonclay minerals quartz, feldspar, and calcite.

The Burro Creek deposit (no. 65, pl. 1) is $12.9 \mathrm{~km}$ west of Bagdad near the Mohave-Yavapai County line (Galbraith and Brennan, 1959, p. 109). The bentonite of this deposit was identified as a magnesium smectite similar to saponite by Miller and others (1987, p. B7). It is in a sequence of lacustrine sedimentary rocks and was derived by diagenetic alteration of silicic tuffs deposited in a alkaline, saline lake environment. The lower part of the dolomite unit that is interbedded with the bentonite has been hydrothermally altered to bentonite (Miller and others, 1987, p. B11). The Burro Creek bentonite has been mined on a small scale for sealing ponds, reservoirs, and ditches. One sample of this bentonite, collected from an old abandoned pit, consists of 96 percent clay and 4 percent sand and silt (table 1, map no. 65). Smectite (saponite) was the only mineral detected by X-ray diffraction.

The Bouse deposit, $3 \mathrm{~km}$ east of Bouse, La Paz [Yuma] County (no. 66, pl. 1), produced a few hundred metric tons of bentonite for use in drilling mud (Wilson and Roseveare, 1949). The deposit occurs in a lake bed of Cenozoic age. One sample from the abandoned Bouse pit is two-thirds clay and one-third sand (table 1, map no. 66). An X-ray diffraction trace of the sample indicated smectite (hectorite) and the nonclay minerals quartz, feldspar, biotite, and a zeolite.

\section{CALIFORNIA}

Although bentonite occurs throughout the State of California, the principal deposits are found in Inyo, Kern, San Benito, San Bernardino, and San Diego Counties. The best known deposits are Otay in San Diego County and Hector in San Bernardino County. However, the deposit at Otay has not produced any bentonite for many years. The most extensive bentonite beds are in the Amargosa River valley, which extends from Ash Meadows, Nye County, Nev., south-southeast through Shoshone to the vicinity of Tecopa, Inyo County, Calif., a distance of almost $100 \mathrm{~km}$.

Bentonite mining in Kern County began in the early 1900 's, with the greatest mining activity between the 1920's and 1945. In 1948, the Federal Government began acquiring the dry lake areas for military uses, and by 1954 almost all mining of bentonite from dry lake beds had ceased (Troxel and Morton, 1962). Most of the bentonite mined was used as an absorbent in refining petroleum products, and the bentonitic clays were used as fillers and as fuller's earth for absorbing grease.

The bentonite resources of California cannot be estimated with any degree of accuracy because most of the bentonite occurs as small deposits in Tertiary lake beds. However, it is likely that the bentonite and bentonitic clay resources in California is 1 billion metric tons (Gt). The major production now comes from the Amargosa River valley, the Hector deposits, and the Vallecitos district, which may contain more bentonite than all other areas in California. In 1988, California produced 124,500 $\mathrm{t}$ of bentonite from 5 mines.

\section{HECTOR DEPOSIT}

The Hector deposit is $57 \mathrm{~km}$ east of Barstow near Interstate Highway 40 (no. 67, pl. 1) in central San Bernardino County, Calif. Bentonite production from this deposit has been continuous since 1931. The principal mineral of this deposit is hectorite, a high-magnesia, lowsilica, swelling bentonite containing about 1 percent lithium. Although hectorite differs chemically from the Wyoming-type bentonite, it has similar physical properties. N L Chemicals was actively producing hectorite in 1986 (California Division of Mines and Geology, 1987, p. 55). Two samples from the Hector deposit consist chiefly of hectorite with about 5 percent calcite and less than 3 percent quartz grains (table 1, map no. 67).

The Hector deposit occurs along a northwest-trending fault for about $8 \mathrm{~km}$. According to Ames and others (1958), the bentonite formed as the result of hot springs activity in a restricted lacustrine environment. Pliocene(?) hot springs along a fault zone discharged hot waters into a nearby lake in which waterborne clastic material and airborne volcanic ash debris were accumulating. The volcanic ash probably came from volcanic eruptions in the Fort Cady Mountains to the northwest (Sweet, 1980, p. 279). Initially the tuff was altered to clinoptilolite from which hectorite formed by the addition of lithium and fluorine supplied from the hot-spring water and magnesium supplied from the lake waters. The hectorite-bearing lake beds are overlain by basalt of probable Holocene age that erupted from the nearby Mount Pisgah volcano.

Most of the hectorite produced has been used for oil well drilling mud, and since 1952, some has been beneficiated for special uses such as in pharmaceutical products and for clarifying beverages (Cleveland, 1957, p. 139). 


\section{PACIFIC DEPOSIT}

The Pacific Mining Company bentonite mine is $10.5 \mathrm{~km}$ northwest of Johannesburg, San Bernardino County, in sec. 29, T. 28 S., R. 41 E. (no. 68, pl. 1) (Wright and others, 1953, p. 161). Several thousand metric tons of bentonite were mined beginning in 1951, but no mining has been reported in recent years. The bentonite, consisting of pale-greenish-yellow clay, occurs in a layer 1.3 to $4 \mathrm{~m}$ thick. The layer dips a few degrees north and is overlain and underlain by Tertiary sandstone and siltstone containing pebbly layers. The bentonite bed was mined underground by three inclined shafts. It was trucked to the Searles Station, shipped by railroad, and processed in a plant at Los Angeles. It was used chiefly as a sealant for reservoirs and canals and in cleansing preparations. Lesser amounts were used in drilling mud and foundry-sand bond.

\section{CAJON DEPOSIT}

The Star Clay Company has mined a small amount of bentonite, for sealing canals and reservoirs, from a clay bed about $5 \mathrm{~km}$ west of Cajon Junction (no. 69, pl. 1), San Bernardino County. The clay bed occurs in an unnamed unit of Miocene age (Rogers, 1967).

\section{OTAY DEPOSIT}

The Otay clay was first described by Goodyear (1890, p. 139) as a high moisture bentonite widely distributed in the Otay Valley. The Otay bentonite deposit (no. 70, pl. 1) is located $17.7 \mathrm{~km}$ south of San Diego, in sections 17 , $18,19,20,29$, and 30 , T. 18 S., R. 1 W., and in section 25 , T. 18 S., R. 2 W. (Cleveland, 1960). The bentonite from this deposit was known locally as otaylite (Melhase, 1926, p. 838). The bentonite occurs as beds in the San Diego Formation (Cleveland, 1960), later renamed the Otay Member of the Rosarito Beach Formation (Kuper and Farrand, 1977), that underlies much of southwestern San Diego County, Calif. Because of its high cation exchange capacity, this bentonite was used as an absorbent, drilling mud, and filler. The deposit has been idle since 1957 .

The Miocene Otay Member consists of poorly consolidated, gray and light-brown, micaceous sandstone and arkose, thin beds of very light brown marl, brown mudstones, and beds of brown, pink, and white bentonite. The Otay Member is overlain by the more resistant Sweitzer Formation. Only $91 \mathrm{~m}$ of the upper part of the Otay Member is exposed, but drill-hole information indicates that the formation is more than $790 \mathrm{~m}$ thick (Cleveland, 1960, p. 7). There are at least six bentonite beds in the exposed part of the Otay Member. They range in thickness from a few centimeters to $1.2 \mathrm{~m}$. The principal and most extensive bentonite beds have an average thickness of about $90 \mathrm{~cm}$, but at some exposures are more than $3 \mathrm{~m}$ thick (Hertlein and Grant, 1939, $\mathrm{p}$. 78).

The principal Otay bentonite was derived from one or more volcanic ash falls that accumulated in a body of water that was relatively free of clastic material. The ash is believed to have come from a southerly direction because the closest known Pliocene volcanic rocks are in Baja California Norte, Mexico, and because the bentonite beds thin to north of the Otay area (Cleveland, 1960, p.11).

\section{VALLECITOS DISTRICT}

Near New Idria, in San Benito County, approximately $21 \mathrm{~km}$ southeast of Panoche (no. 80, pl. 1), the WilberEllis Company mined bentonite from a zone that contained both swelling and nonswelling varieties. The bentonite zone is near the base of the Kreyenhagen Formation of Eocene and Oligocene age, underlain by the Domengine Formation (middle Eocene), and overlain by the Temblor Formation of Oligocene and Miocene age. The zone contains at least four bentonite beds; each bed is more than $15 \mathrm{~m}$ thick (Cleveland, 1957, p. 139) and is in a belt that stretches from 3 to $21 \mathrm{~km}$ northwest of New Idria. However, much of the bentonite in this district is in steeply dipping beds, and differential thermal analysis studies by Aune and others (1959, p. 16-17) show considerable variation in crystallinity of the smectite-possibly caused by thermal changes related to depth of burial-indicating that most of the Vallecitos bentonites are not high quality. The bentonites are gray to white and formed by alteration of volcanic ash. They have been used for sealing canals and reservoirs and as an insecticide carrier (Kelley, 1966, p. 133). Laboratory tests on samples of Vallecitos bentonites show that they could be used for drilling mud and in other applications requiring swelling properties (Aune and others, 1959, p. 42).

\section{AMARGO DEPOSIT}

The Amargo bentonite deposit in $\mathrm{N}_{2} \mathrm{NE}_{2} 1_{4}$, sec. 26, $\mathrm{T}$. $11 \mathrm{~N}$., R. $8 \mathrm{~W}$., is $4.8 \mathrm{~km}$ northwest of Boron (no. 71, pl. 1). The poorly exposed bentonite is about $6 \mathrm{~m}$ thick (Troxel and Morton, 1962, p. 72), and it occurs in a lake-bed unit that may be correlated with the Tropico Group of Oligocene and Miocene age. The clay is greenish gray, contains sand, and swells slightly; it has an overburden of soil and shale about $1 \mathrm{~m}$ thick. The clay has been sold to the laundry industry as a grease absorbent in which soda ash was added to increase the cleansing properties (Troxel and Morton, 1962, p. 72).

\section{TEHACHAPI DEPOSIT}

The Tehachapi bentonite deposit in sec. 2, T. $32 \mathrm{~S} ., \mathrm{R}$. $34 \mathrm{E}$., and sec. 34 , T. 31 S., R. 34 E., is about $14.5 \mathrm{~km}$ 
northeast of Tehachapi (no. 73, pl. 1), Kern County. The deposit, which consists of a 2.4-m-thick claystone layer over an area of at least $65 \mathrm{~km}^{2}$, is in the Miocene Kinnick Formation. The layer consists of grayish-white to white clay and volcanic ash partly altered to montmorillonite. The nonclay minerals are volcanic glass shards, zeolite (probably heulandite), and feldspar. The material does not swell and is naturally active (Kerr and Cameron, 1936 , p. 233). Tests indicate that the bentonite has natural bleaching properties.

\section{MUROC DEPOSIT}

The Muroc deposit, in secs. 2 and 3, T. 11 N., R. 9 W., is about $34 \mathrm{~km}$ east of Mojave, near North Muroc (no. 72, pl. 1), Kern County. The bentonite occurs as beds in a sequence of lacustrine clastic sediments that are capped by basalt. This sequence is in the lower part of the Oligocene and Miocene Tropico Group (Dibble, 1958). The principal bentonite bed is about $1.8 \mathrm{~m}$ thick. It is nonswelling, almost pure white, and hard when fresh. Large amounts of bentonite were mined by the Muroc Clay Company during the 1920 's and 1930 's. The bentonite has been used as an absorbent in refining petroleum products. It is naturally active and can be classed as a fuller's earth (Troxel and Morton, 1962, p. 74).

\section{MCKITTRICK DEPOSIT}

A deposit of mudstone, mined by the McKittrick Mud Company, is located in NW1/4 SE1/4 sec. 14 and NW1/4 SW1/4 sec. 13, T. 30 S., R. 21 E., about $4.8 \mathrm{~km}$ west of McKittrick (no. 76, pl. 1), Kern County. The deposit consists of pale-greenish-gray mudstone about $46 \mathrm{~cm}$ thick. The mudstone apparently accumulated from the erosion of surrounding marine Miocene formations in a small depression formed along an east-trending fault zone. The mudstone swells slightly, and according to Troxel and Morton (1962, p. 73), it contains some bentonite. During the 1950 's, this material was used primarily in drilling muds; currently it is used for sealing reservoirs and irrigation ditches.

\section{IRON CANYON DEPOSIT}

The Iron Canyon bentonite deposit (no. 75, pl. 1), in sec. 25, T. 29 S., R. 37 E., $9.5 \mathrm{~km}$ north of Cantel, Kern County (Troxel and Morton, 1962, p. 77), consists of gray to $\tan$ waxy bentonite that is locally gypsiferous. The bentonite bed is 1.5-3 $\mathrm{m}$ thick and is overlain by about 15 $\mathrm{m}$ of tuffaceous sand and a layer of dark-gray volcanic rock. The bentonite bed and the sand unit are part of the Ricardo Formation of Miocene and Pliocene age (Dibble and Gay, 1952). Several thousand metric tons of benton- ite have been produced from the Iron Canyon deposit (Troxel and Morton, 1962, p. 77).

\section{SNOW WHITE DEPOSIT}

The Snow White bentonite deposit (no. 74, pl. 1), Kern County, in sec. 30 , T. 29 S., R. 38 E., is in a bed $5 \mathrm{~m}$ thick (Troxel and Morton, 1962, p. 79). The bentonite is tan and white and is intercalated with siliceous bentonitic clays. It is overlain by greenish-gray tuff and dark-gray voleanic flows of the Ricardo Formation (Dibble and Gay, 1952). The bentonite contains fresh, angular fragments of fine-grained volcanic rock and quartz up to $2.5 \mathrm{~cm}$ in the largest dimension. Two open pits on the Snow White property produced many tens of thousands of metric tons of bentonite in the 1920's and 1930's, but no production has been reported in recent years.

\section{OLANCHA DEPOSIT}

At the southern end of Owens Lake, east of Olancha (no. 79, pl. 1), Inyo County, the Sierra Talc and Clay Company formerly mined a deposit of nonswelling bentonite. Norman and Stewart (1951, p. 98) called this deposit the Calearth clay deposit. It is a 5 -m-thick bed of bentonite formed by the alteration of a volcanic tuff by hydrothermal solutions. The bentonite is overlain by a 3to 6-m-thick layer of Tertiary or Pleistocene basalt and had to be mined underground (Cleveland, 1957, p. 139). The bentonite is naturally absorbent but was treated with acid before use. The deposit is classed as a fuller's earth and was used as a filtering and decolorizing agent (Kelly, 1966, p. 132). The deposit has not been mined since the 1950's.

\section{AMARGOSA (RIVER VALLEY) DISTRICT}

The most extensive bentonite beds in California are those along the Amargosa River in Inyo County, Calif., and Nye County, Nev. The bentonite in this Amargosa district (no. 55, pl. 1) was known as amargosite (Tucker, 1926 , p. 514). The district includes the Shoshone and Tecopa deposits in California and the Ash Meadows deposit in California and Nevada. The Ash Meadows bentonite deposit is discussed in the Nevada section.

Shoshone deposit. - Bentonite, also called shoshonite (Wayland, 1970, p. 42), was formerly mined by the Associated Oil Company along the right-of-way of the Tonopah and Tidewater Railway near Shoshone (Melhase, 1926, p. 838) in sec. 25, T. 22 N., R. $6 \mathrm{E}$ (no. 77, pl. 1). The bentonite bed is $2-3 \mathrm{~m}$ thick overlain by $1-4.5 \mathrm{~m}$ of overburden (Norman and Stewart, 1951, p. 204) and extends over at least $100 \mathrm{hm}^{2}$.

The deposit near Shoshone was also mined by the Filtrol Company, and the bentonite was shipped to a 
plant in Los Angeles where it was processed for use as a bleaching clay (Spence, 1924, p. 11). Later, the deposit was mined by the Sierra Talc and Clay Company (Wayland, 1970, p. 42). The bentonite bed is $2-3 \mathrm{~m}$ thick with $1-4.5 \mathrm{~m}$ of overburden (Tucker, 1926, p. 514). Although mineralogical data are not available, the deposit apparently consists of nearly pure montmorillonite.

Tecopa deposit. - The Tecopa bentonite deposit (no. $78, \mathrm{pl} .1$ ) is in the basin of the former Pleistocene Lake Tecopa in sec. 4, T. 20 N., R. $7 \mathrm{E}$ in southeastern Inyo County. The town of Tecopa is about $2 \mathrm{~km}$ south of the deposit. During Pleistocene time, the Amargosa River was blocked at a point south of the present town of Tecopa, and the lake that formed behind the dam became the basin of deposition for detrital material carried by the river and of air-fall volcanic ash. The detritus consisting of clays, quartz, feldspars, and micas formed mudstones, and siltstones and the ash formed interlayered tuffs beds. The bentonite, formed by the alteration of the tuff beds, varies from almost white to pastel shades of light brown, light green, and pink. The mudstone breaks with a conchoidal or subconchoidal fracture and is about $2 \mathrm{~m}$ thick (Tucker, 1926, p. 513). The predominant clay mineral is a lithium-bearing saponite (Starkey and Blackmon, 1979, p. 23), which does not contain enough lithium to be classified as hectorite. Starkey and Blackmon $(1979$, p. 23) believed the saponite to be detrital and derived from a nonhydrothermal source outside of the basin. The small amount of montmorillonite in or near the tuff beds is the result of saline waters altering the siliceous glass in the volcanic ash. The sepiolite found just below the base of the uppermost tuff bed is probably authigenic in origin.

\section{OTHER DEPOSITS}

In 1986, two companies were mining bentonite at localities (California Division of Mines and Geology, 1987, p. 50) for which the authors were unable to find any information. The American Colloid Company reportedly produced bentonite from its Kingston Springs mine located in sec. 34 , T. 18 N., R. 9 E.; San Bernardino County and the United States Tile Company produced bentonite from its Victorite clay mine located in sec. 7, T. 7 N., R. 2 W., San Bernardino County.

\section{COLORADO}

A few small deposits of bentonite in Colorado have been mined in the past for several uses. A bentonite deposit in the Creede Formation of Oligocene age was mined on a small scale for several years near Creede, Mineral County, and used for clarifying oils (Larsen, 1930, p. 108-109; Nutting, 1943, p. 151). This bentonite, formed by the alteration of a rhyolitic tuff, is more than $6 \mathrm{~m}$ thick at one locality, is composed of montmorillonite, and contains minor amounts of biotite, feldspar, and volcanic glass.

The bentonite deposit having the largest areal extent in Colorado is 17.5 to $27.0 \mathrm{~km}$ southeast of La Junta (no. $39, \mathrm{pl} .1$ ). Bentonite was mined from at least four pits in an area of about $200 \mathrm{~km}^{2}$, one is in Otero County, sec. 36 , T. 26 S., R. 54 W., and the other three are in Bent County, sec. 19, T. 27 S., R. 53 W., sec. 6 , T. 28 S., R. $52 \mathrm{~W}$., and sec 9 , T. 27 S., R. $53 \mathrm{~W}$. The bentonite bed is medium to greenish gray, ranges in thickness from $61 \mathrm{~cm}$ to $7.6 \mathrm{~m}$, and is in the Morrison Formation of Late Jurassic age. It is overlain by sandstone in some places and shale in others, and, at many places, it is underlain by a chert bed. The bentonite from this area was used primarily for sealing reservoirs, irrigation ditches, and stock ponds. Patterson (1964, p. 184) stated that a few thousand tons were shipped to Texas in 1950 for use in drilling mud.

Small amounts of bentonitic clay have been mined from the Brushy Basin Member of the Morrison Formation (Lohman, 1965, p. 15) southeast from Grand Junction, Mesa County (no. 41, pl. 1). This clay was used to control seepage of water from stock ponds. Bentonitic clay in the Brushy Basin Member was also mined a few kilometers southwest of Grand Junction, near the Colorado National Monument. The material was mixed with shale to obtain a clay that had suitable plasticity for making common brick and other structural clay products (Van Sant, 1959, p. 141).

In Fremont County (no. 40, pl. 1), approximately 22 $\mathrm{km}$ southeast of Salida, bentonite was mined by the Star Rocker Bentonite Company primarily for sealing irrigation ditches and stock ponds. The bentonite is cream colored and occurs as a bed $152 \mathrm{~cm}$ thick. It formed by the alteration of an ash-flow welded tuff of Tertiary age. The deposit is located in the very narrow valley of the Arkansas River and is limited in size.

A deposit of bentonitic clay is located about $37 \mathrm{~km}$ northwest of Sterling in sec. 2, T. 9 N., R. 56 W., in Weld County near the Logan County line (no. 38, pl. 1). The clay is exposed in an old pit that was probably opened to mine clay for lining irrigation ditches and stock ponds. It is approximately $3 \mathrm{~m}$ thick, and, according to the geologic map of Colorado (Tweto, 1979), is in the Oligocene White River Formation.

\section{FLORIDA}

The Meigs-Attapulgus-Quincy palygorskite-type fuller's earth district is in southern Georgia and extends into 
part of northern Florida. Since a major portion of the fuller' earth occurs in Georgia, this district is described in the Georgia section.

A bentonite-type fuller's earth is mined from a pit in sec. 4, T. 13 S., R. 20 E., and processed by the MidFlorida Mining Company at Lowell, Marion County (no. 7, pl. 1) (Campbell, 1986, p. 63). This area is near the southern extremity of the Hawthorn Group outcrop belt, and the clay currently being mined is from the lower part of the Hawthorn Group of Miocene and Pliocene age. It is underlain by the Eocene Ocala Limestone and is overlain by undifferentiated sands, sandy clays, and clayey sands. The clay bed is approximately $8 \mathrm{~m}$ thick, and the overburden has a maximum thickness of about $8.5 \mathrm{~m}$ (Campbell, 1986, p. 6). One sample collected from the clay pit contained 96 percent clay, 4 percent sand, and a trace of silt. The clay minerals, as determined by X-ray diffraction, are chiefly montmorillonite and a minor amount of illite. The nonclay minerals are quartz and cristobalite.

\section{GEORGIA}

Two types of fuller's earth deposits are found in Georgia-the unique palygorskite (attapulgite) deposits of the Meigs-Attapulgus-Quincy district, southwest Georgia and northern Florida, and the bentonite-type fuller's earth deposits that occur both in the northern part of the Meigs-Attapulgus-Quincy district and the Twiggs clay belt, central and east-central Georgia.

\section{MEIGS-ATTAPULGUS-QUINCY DISTRICT}

The Meigs-Attapulgus-Quincy fuller's earth district is in Grady, Decatur, and Thomas Counties, Ga., and Gadsden County, Fla. (no. 5, pl. 1). About two-thirds of the district is in southern Georgia, and about one-third is in northern Florida. This area has been the leading producing district of fuller's earth since 1895 . The deposits are in a belt extending from near Meigs, Ga., southwest to Quincy, Fla., a distance of about $80 \mathrm{~km}$. The deposits occur as discontinuous beds and lenses in the Hawthorn Group of Miocene and Pliocene age (fig. 10). In the southern part of the district, in the vicinity of Attapulgus, Ga., and Quincy, Fla., the fuller's earth consists predominantly of palygorskite (fig. 7 , tables 2,4 ) but contains minor amounts of montmorillonite and the nonclay minerals quartz, dolomite, calcite, phosphate pellets, feldspars, and a variety of heavy minerals. Kaolinite occurs in the upper part of the deposits under thin overburden, where it is apparently a weathered product of montmorillonite, which in turn formed by weathering of palygorskite. The deposits, near Meigs, Ga., in the northern part of the district, are composed chiefly of montmorillonite and minor amounts of palygorskite and sepiolite, abundant diatoms, and the nonclay minerals quartz, feldspar, calcite, dolomite, and a variety of heavy minerals. The deposits in this part of the district are thicker and more continuous that those in the southern part of the district. For example, deposits mined near Meigs, Ga., are 9.8-14.3 m thick; deposits near Attapulgus, Ga., and Quincy Fla., range from $2 \mathrm{~m}$ to slightly more than $3 \mathrm{~m}$ in thickness (Patterson, 1974, p. 18).

Although fuller's earth in the Meigs-AttapulgusQuincy district was formerly used for purifying oils, in 1988 , only 1.6 percent was used for this purpose. The major uses now are for litter and bedding for poultry, pets, and other animals, as an adsorbent of oil and grease, as a soil conditioner, and as a drilling mud where saltwater is present (Patterson, 1974, p. 15). In 1989, fuller's earth was mined and processed by the Englehard Minerals \& Chemicals Corporation and the Milwhite Company, Inc., at Attapulgus, Ga.; by the Floridin Company and the Oil Dry Production Corporation at Ochlocknee, Ga.; by the Waverly Minerals Product Company and the Thor Mining Company near Meigs, Ga.; and by the Pennsylvania Glass Sand Corporation at Quincy, Fla.

According to Patterson (1974), the origin of the fuller's earth deposits of the Meigs-Attapulgus-Quincy district is uncertain. The deposits apparently formed in very shallow marine lagoons or tidal flats. The additional magnesium needed to form the minerals palygorskite, sepiolite, montmorillonite, and dolomite apparently was introduced by reaction of detrital material with magnesiumrich brines and salt resulting from the evaporation of entrapped seawater. The detrital material that was transported by streams supplied the silica and alumina for the clay minerals. Both dolomite and palygorskite probably formed in hypersaline lagoons; the dolomite formed under conditions of either greater salinity or under conditions when lesser amounts of silicon and aluminum were available from the clastic sediments entering the basin (Weaver and Beck, 1972, p. 55; Weaver, 1975). Evidence is lacking for the alternate theory that volcanic ash was the major parent material.

\section{TWIGGS CLAY BELT}

The Upper Eocene Twiggs Clay Member of the Dry Branch Formation of the Barnwell Group (Huddlestun and Hetrick, 1979) extends throughout an extensive belt in central and east-central Georgia. The Twiggs Clay Member has a variable composition, part of it is lenticular clay units, most of it is sand and silt, and locally the clay beds grade into sand beds of other formations in the Barnwell Group. Only the clay-rich parts of the Twiggs 
Clay Member have any value as a fuller's earth. The principal clay mineral is calcium-montmorillonite, but minor amounts of kaolinite and illite occur locally (Brindley, 1957; Hetrick, 1982). Opaline cristobalite is present in much of the Twiggs clay, and it makes up as much as 50 percent of some deposits (Grim and Güven, 1978, p. 38). Even the purest clay of the Twiggs Clay Member contains considerable quartz sand and silt.

Minor amounts of Twiggs clay have been mined near Toomsboro and McIntyre, Wilkinson County (Bay, 1940, p. 272-274), but most of the production has come from the Pikes Peak deposit (no. 4, pl. 1) in Twiggs County and the Wrens deposit (no. 3, pl. 1) in Jefferson County. The Pikes Peak deposit was mined in an area about $2 \mathrm{~km}$ northeast of the Stone Creek Church, between Macon and Jeffersonville (Buie and others, 1979, p. 32-33). For many years, clay was hauled from these mines in this area to a plant in Macon. Because of dust emission and other environmental problems, this plant was closed in the late 1970's.

At the Wrens deposit, Jefferson County, fuller's earth was recovered from a layer in the Twiggs Clay Member approximately $8 \mathrm{~km}$ long and $2 \mathrm{~km}$ wide. The material is processed at a plant in Wrens operated by the GeorgiaTennessee Mining and Chemical Co., primarily for absorbent granules (Carver, 1972). For the most part, the layer has a thickness of about $3 \mathrm{~m}$, but locally it is as much as $10 \mathrm{~m}$ (Sandy and others, 1966, p. 20-22). Elsewhere in the Wrens district, fuller's earth occurs in layers or lenses in which the upper surface is irregular, and in places, gravel-filled channels have been cut into or completely through the clay layers. The irregularities and channels are due to erosion prior to the deposition of the overlying younger beds.

Two old abandoned fuller's earth pits have been reported in Stewart County (no. 6, pl. 1) (Zap and Clark, 1965 , p. H8), $1.6 \mathrm{~km}$ south of the Ben Daniel school and $8 \mathrm{~km}$ northwest of Troutman along a secondary road. Zap and Clark (1965) noted that the pits were in the Midway Group of early Paleocene age (fig. 10). However, our more recent geologic data indicate that fuller's earth in this area is probably in the Porters Creek Clay (fig. 9), and the principal clay mineral is probably smectite. Zap and Clark did the field work for their report in 1943.

\section{FULLER'S EARTH RESOURCES}

The total amount of fuller's earth in the MeigsAttapulgite-Quincy district is large, but specific information about the total resources is not available. Thousands of exploratory holes have been drilled, but most of these data are of a proprietary nature. Patterson (1974, p. 28) suggested that the fuller's earth resources in the MeigsAttapulgus-Quincy district is many times an original estimate of 15.68 Mt by Sellards and Gunter (1909, p. 285) because (1) this estimate was only for Gadsden County, Fla., (2) the strippable limit of overburden is now about six times their estimate of 3.1-4.6 m, and (3) the fuller's earth beds in the northern part of the district are about three times thicker than those in Gadsden County.

\section{IDAHO}

Bentonite has been mined about $22 \mathrm{~km}$ west of Grand View, Owyhee County (Hosterman and Prater, 1964, p. 55), in the old Ben-Jel pit located $2 \mathrm{~km}$ west of Castle Creek in the SW1/4 of sec. 20, T. 5 S., R. 1 E. (no. 45, pl. 1). In this area, the USBM (U.S. Bureau of Mines, 1958-62) reported that a small amount of bentonite was produced from 1956 to 1961 for local use in sealing potato cellars, irrigation ditches, and reservoirs and for drilling $\mathrm{mud}$. The bentonitic bed, exposed in an area of $213 \mathrm{~m}$ by $152 \mathrm{~m}$ (Asher, 1965, p. 138), is about $4.6 \mathrm{~m}$ thick and overlies siliceous volcanic tuff. The bentonite is yellowish gray when wet and almost white when dry, with gypsum crystals scattered throughout.

A small amount of bentonitic clay was mined from two small pits about $8 \mathrm{~km}$ southeast of Salmon, Lemhi County (no. 43, pl. 1), for local use in sealing irrigation ditches and stock ponds. The clay bed is in the Miocene Kirtley Formation of Anderson (1959, p. 27), which was renamed by Anderson from the Carmen Formation but has since been abandoned by Ruppel and Lopez (1988). One clay pit is east of U.S. route 93 in sec. 23 , and the other is west of State route 28 in sec. 28 T. 21 N., R. 22 E. The clay bed ranges in thickness from a few centimeters to several meters and is interbedded with siliceous shales and sandstones (Anderson, 1956, P. 99). It is greenish gray to almost white and consists of montmorillonite and abundant impurities of quartz, biotite, and gypsum. The bentonite bed appears to be of sedimentary origin derived from the erosion of tuffaceous material in the Challis Volcanics (Anderson, 1956, p. 100).

About $24 \mathrm{~km}$ west of Dubois, in an area around Lidy Hot Springs, Clark County (no. 44, pl. 1), an abandoned mine tunnel exposes $3 \mathrm{~m}$ of clay overlain by 0.9 - to 1.2-m-thick limestone (Asher, 1965, p. 142). The clay, which is greenish gray to almost white and contains calcite crystals, was once mined by E.D. Wilson \& Sons. Kirkham (1927, p. 42) believes the clay to be bentonite; however, no tests have been made to identify the clay or to determine its physical and chemical properties.

\section{ILLINOIS}

Fuller's earth production in Pulaski County began in 1920, and until 1926 Illinois was the Nation's leading 
producer. Two companies, Absorbent Clay Products, Inc., and Lowe's Southern Clay Company, Inc., are currently mining clay from pits near Olmsted (no. 13, pl. 1) (Samson and Masters, 1987, p. 3). Both companies are producing clay for use as a floor sweeping compound to adsorb oil and grease (Searight and others, 1967, p. 116). The clay is in the Porters Creek Clay, which is part of the Paleocene Midway Group (figs. 9 and 10). It is $4.5-12 \mathrm{~m}$ thick and is covered by $4.5-9 \mathrm{~m}$ of overburden (Lamar, 1928). According to Bohor and Khandelwal (1968), a sample of Porters Creek Clay, taken from a pit in NE1/4 $\mathrm{SE} / 4$ sec. 27 , T. $15 \mathrm{~S}$., R. 1 E., contains 55 percent montmorillonite and 15 percent each of kaolinite, illite, and chlorite. The only nonclay mineral is cristobalite, which occurs in trace amounts.

\section{KANSAS}

There has been no known production of bentonite in Kansas, but there are occurrences of bentonite in Phillips and Wallace Counties. The bentonite formed by the devitrification and decomposition of volcanic ash, and it consists of montmorillonite and small amounts of admixed feldspar, biotite, and volcanic glass. Kinney (1942), who tested several bentonite samples from both areas, concluded that the material from these occurrences could be used as clarifiers and for sand bonding but that they were inferior to the Wyoming bentonites for use in drilling muds.

In Phillips County, bentonite occurrence is in sec. 10, T. 1 S., R. 18 W., and SE $1_{4}$ sec. 35 , T. 1 S., R. $20 \mathrm{~W}$ (no. 21, pl. 1). The bentonite was reported to be as much as $7.6 \mathrm{~m}$ thick in several auger holes (Kinney, 1942, p. 355) and is between the Pierre Shale and the underlying Niobrara Chalk of Late Cretaceous age. The clay is bluish gray, greenish gray, to very light gray, and the overburden is $1-6 \mathrm{~m}$ thick.

In Wallace County, the bentonite is part of the Ogallala Formation of Miocene age. It is in the SW1/4 sec. 19 and SW1/4 sec. 2, T. 12 S., R. $41 \mathrm{~W}$ (no. 22, pl. 1), where it occurs as isolated mounds. Typically, the mounds are $137 \mathrm{~m}$ long, and the bentonite is $14 \mathrm{~m}$ thick; the overburden ranges in thickness from 3 to $12 \mathrm{~m}$ (Kinney, 1942, p. $355)$. The clay is pale olive green to pale greenish white. Each mound may contain as much as $150,000 \mathrm{t}$ of bentonite.

\section{KENTUCKY}

In Kentucky, the Porters Creek Clay of Paleocene age is exposed in an arcuate belt west of and parallel to the Kentucky Lake and south of and parallel to the Tennessee River. The formation crops out in Calloway, Mar- shall, Graves, McCracken, and Ballard Counties. The Porters Creek consists of fine-grained, slightly to very micaceous clay and thin layers and lenses of fine-grained, micaceous sand. The unweathered dry clay is light gray and almost black when wet. The formation is $46-76 \mathrm{~m}$ thick (McGrain, 1965, p. 6). The best grade bentonite beds range in thickness from 3 to $15 \mathrm{~m}$ (McGrain, 1956). Although no commercial fuller's earth has been produced from Kentucky in recent years, there are several billion tons based on the outcrop belt of the Porters Creek Clay and the thickness of the bentonite bed of fuller's earth in Kentucky.

\section{LOUISIANA}

Two abandoned bentonite mines are known in Louisiana, one is $1.5 \mathrm{~km}$ southwest of Hornbeck, Vernon Parish (no. 16, pl. 1), and the other is $7 \mathrm{~km}$ west-southwest of Bogalusa, Washington Parish (no. 15, pl. 1) (Hosterman, 1984 , p. C16). According to Welsh (1942, p. 76), bentonite was mined from the pit near Hornbeck, T. 4 N., R. 10 W., in 1942, for use as a drilling mud. This bentonite is in the lower part of the Fleming Formation of Miocene and Pliocene age (fig. 10). One sample of yellowish-gray bentonite from the pit contained 10 percent quartz silt and 90 percent clay, composed of 95 percent montmorillonite and 5 percent kaolinite (map no. 16, table 1) (Hosterman, 1984, p. C16). According to Dixon (1967), bentonite from the pit near Bogalusa, sec. 30, T. $3 \mathrm{~S}$., R. $13 \mathrm{E}$., was used as a drilling mud and as an absorbent. This bentonite is in the Fleming Formation (Dixon, 1967, p. 92) of Miocene and Pliocene age. One sample of lightgray bentonite from this pit was found to consist of 2 percent sand, 13 percent silt, and 85 percent clay (map no. 15 , table 1). The clay, as determined by X-ray diffraction, was found to consist of 85 percent montmorillonite, 10 percent kaolinite, and 5 percent illite (Hosterman, 1984, p. C16).

\section{MISSISSIPPI}

Bentonite mining in Mississippi began with a small operation in Prentiss County in 1930. In a few years, bentonite was being commercially produced from Monroe and Itawamba Counties. The bentonite mined in all three counties was from the Cretaceous Eutaw Formation.

\section{ABERDEEN DEPOSIT}

A bentonite bed occurs in the Eutaw Formation (fig. 10) of Cretaceous age, near Aberdeen in Monroe County (no. 10, pl. 1) and extends northward into Itawamba County. The best grade material in this bed contains a 
very small amount of quartz sand, less than 10 percent quartz silt, and more than 90 percent clay (Hosterman, 1984 , p. C17). The clay fraction is composed of 100 percent calcium montmorillonite (table 1 , map no. 10). The clay is medium to light gray, weathers to light yellowish brown, and is $4.5-6 \mathrm{~m}$ thick. The bentonite here is being mined by the American Colloid Company and the International Minerals \& Chemicals Corporation chiefly for use as an absorbent (Bicker, 1970, p. 28).

Although evidence exists that the Cretaceous bentonites of the Gulf of Mexico Coastal Plain were derived from the decomposition of volcanic ash, the question remains; where were the volcanoes located? According to Lyons (1957) and Ross and others (1929), an arc of volcanoes existed southeast of the Gulf of Mexico during Late Cretaceous time, which may have been the source for the volcanic ash material that was the parent material for the bedded bentonite. However, according to Merrill (1983), most of the volcanic ash materials for the bentonite deposits in Mississippi were derived from the Midnight Volcano and associated volcanic structures on the Sharkey Platform located approximately 195-240 $\mathrm{km}$ west-southwest of Monroe County. Minor amounts of volcanic material may have come from the volcanoes associated with the Jackson Dome in Hines and Rankin Counties and from the Door Point volcanic sequence located farther south in the vicinity of the present Mississippi River delta.

\section{RIPLEY-BLUE MOUNTAIN DEPOSITS}

Bentonite in the Paleocene Porters Creek Clay of the Midway Group (figs. 9 and 10) is found near Ripley and near Blue Mountain in Tippah County (no. 11, pl. 1). The best grade bentonite contains almost 100 percent claysize material and only traces of quartz silt and sand (Hosterman, 1984, p. C17). This clay is composed of 80-90 percent calcium montmorillonite and 10-20 percent illite (table 1, map no. 11). The clay is medium to light gray, weathers to light yellowish brown, and ranges in thickness from 2.5 to $6 \mathrm{~m}$. The bentonite is being mined by International Minerals \& Chemicals Corporation and Oil Dry Production Corporation and is used chiefly as a fuller's earth or absorbent (Bicker, 1970, p. 28).

In 1988, approximately $300,000 \mathrm{t}$ of bentonite and fuller's earth were produced annually in Mississippi. Probably more than $10 \mathrm{Mt}$ of bentonite resources exist in the Eutaw Formation, and at least several billion metric tons of fuller's earth resources exist in the Porters Creek Clay.

\section{MISSOURI}

Bentonitic Porters Creek Clay (figs. 9 and 10) crops out in very large areas in Scott and Stoddard Counties of southeast Missouri (no. 14, pl. 1). The Porters Creek Clay is dark gray to almost black when wet but is light gray to cream colored when dry. Allen (Farrar and others, 1935, p. 75) recognized the Porters Creek Clay as bentonitic and estimated it to be composed of 80 to 95 percent montmorillonite. Allen identified volcanic glass shards in the clay, which implies that the clay was altered from volcanic ash. However, Pryor and Glass (1961) believe that the montmorillonite accumulated by selective sedimentation in the basin of deposition and was not derived in place from the decomposition of volcanic ash.

Physical tests reported by Farrar and others (1935, p. 51-71) indicate that the Porters Creek Clay has oilbleaching properties only. According to Searight and others (1967, p. 116), clays similar to the Porters Creek Clay have been used for drilling mud, foundry-sand bonding, and petroleum refining; however, the clays in Missouri are generally inferior for these uses. Several companies have mined and processed the bentonitic Porters Creek Clay in the past, but only one company, Lowe's Southern Clay, Inc., is currently producing an absorbent clay from a pit near Broomfield, Stoddard County, and from a pit near Oran, Scott County (Warton and others, 1969).

The bentonitic Porters Creek Clay resources are probably on the order of 2-3 Mt, which represents approximately 20-30 yr production at the current rate of 100,000 $\mathrm{t} / \mathrm{yr}$.

\section{MONTANA}

Bentonite has been mined in five localities or districts in Montana: (1) the Hardin district, Big Horn County; (2) the Glasgow-Malta district, Valley and Phillips Counties; (3) the Vananda district, Treasure and Rosebud Counties; (4) the northern Black Hills district, Carter County; and (5) the Bighorn district, Carbon County. The principal bentonite production of the last two of these districts are in adjacent Wyoming, and these districts are discussed under Wyoming.

\section{HARDIN DISTRICT}

The Hardin district (no. 29, pl. 1) is along the northeast flank of the Bighorn Mountains chiefly in Big Horn County, Mont., but it extends a very short distance into Sheridan County, Wyo. (Knechtel and Patterson, 1956). The district is mostly within the Crow Indian Reservation and includes the Custer Battlefield National Monument. 
According to Knechtel and Patterson (1956, pl. 2), 24 bentonite beds in the Thermopolis Shale, Mowry Shale, Cody Shale, and Bearpaw Shale have been identified in the Hardin district. Tests of a few samples from the Clay Spur Bentonite Bed (samples 49-52-JH-82, table 1), at the top of the Mowry Shale, indicate that this bed contains the highest quality bentonite in the Hardin district. However, because the overburden is too thick for strip mining, the Clay Spur Bentonite Bed has limited economic potential. The Soap Creek Bentonite Bed (samples 45, 53-56-JH-82, table 1) in the Belle Fourche Member of the Cody Shale has been mined and contains very large tonnages of bentonite. It has the best economic potential of all the bentonite beds of this district. Other bentonite beds that may be marginally economic are $\mathrm{M}, \mathrm{R}$, and V (samples 37-44-JH-82, table 1).

The lowest stratigraphic bentonite bed is the Clay Spur Bentonite Bed, which is cream (weathered) to darkgreenish-gray (unweathered) bentonite and ranges in thickness from $48 \mathrm{~cm}$ to $3 \mathrm{~m}$ throughout the western and southern part of the district (Knechtel and Patterson, 1956, pl. 1). However, most of the Clay Spur Bentonite Bed lies in positions that are unfavorable for strip mining.

The Soap Creek Bentonite Bed is about $89 \mathrm{~m}$ above the contact with the underlying Mowry Shale. The total thickness of the Belle Fourche is approximately $147 \mathrm{~m}$ (Knechtel and Patterson, 1956, p. 20). This bentonite is also cream to grayish green and has a thickness range from 1.5 to $13.5 \mathrm{~m}$; the unusually thick Soap Creek Bentonite Bed is due to the flowage of bentonite into a small dome. The Soap Creek Bentonite Bed has the best economic potential and the largest reserves of any bed in the district.

Bentonite bed M, at the base of the Greenhorn Calcareous Member of the Cody Shale, is found exposed in the southern part of the district. The bentonite is waxy, yellow, brownish yellow, light green to greenish gray and ranges in thickness from 1.9 to $10 \mathrm{~m}$. Bentonite bed $R$ occurs in an unnamed sandy member of the Cody Shale that is equivalent to the Eagle Sandstone (Knechtel and Patterson, 1956, pl. 2) and crops out in the area west of the Little Bighorn River in the southern part of the district. This bed is light yellowish gray to dark bluish gray and has a thickness of 1.9-2.7 m. Bentonite bed V occurs near the middle of the Bearpaw Shale east of the Little Bighorn River in the northern part of the district. Bed V is as much as $7 \mathrm{~m}$ thick, and some of it is suitable for bonding foundry sand.

\section{MALTA-GLASGOW DISTRICT}

In Valley and Phillips Counties, two bentonite beds have been mined in an area south of the Milk River between Fort Belknap Indian Reservation on the west and Fort Peck Indian Reservation on the east. The Upper Cretaceous Bearpaw Shale (fig. 8) of the Montana Group occurs as a dark-gray montmorillonitic shale, which weathers to a tan or gray soil throughout much of northern Montana. Calcareous layers and ferruginous concretions occur throughout the shale. Several bentonite beds occur in the Bearpaw Shale; most are less than $16 \mathrm{~cm}$, but some are as much as $1.2 \mathrm{~m}$ thick. The two thickest beds, designated X and Y by Berg (1970), occur near the base of the formation.

The Federal Bentonite Company mined and processed bentonite from beds $\mathrm{X}$ and $\mathrm{Y}$ at a locality about $33 \mathrm{~km}$ west-southwest of Glasgow, Valley County, in sec. 3, T. 26 N., R. 36 E. (no. 26, pl. 1 and table 1). The upper (X) bed is light yellowish gray to cream, is $0.6-0.9 \mathrm{~m}$ thick, and was the most extensively mined. The $\mathrm{Y}$ bed, about $4.5 \mathrm{~m}$ below $\mathrm{X}$ bed, consists of medium-gray clay and is $0.5-0.6 \mathrm{~m}$ thick.

The American Colloid Company has mined and processed bentonite from the $\mathrm{X}$ and $\mathrm{Y}$ beds about $35 \mathrm{~km}$ south of Malta, Phillips County, in sec. 6, T. 26 N., R. 31 E. (no. 27, pl. 1 and table 1). The upper $\mathrm{X}$ bed is $0.6-0.9 \mathrm{~m}$ thick and is yellowish gray to cream color. The lower $\mathrm{Y}$ bed is 0.5-1.2 $\mathrm{m}$ thick, light to medium gray, and 2.4-2.7 $\mathrm{m}$ below the upper $\mathrm{X}$ bed.

The bentonite produced by these two companies was used for a binder for taconite iron ore (Hosterman, 1985). Three samples of bentonite from this district were tested by Berg (1969) and showed the material was not suitable for drilling mud.

\section{VANANDA DISTRICT}

Another area of a well-known bentonite occurrence is in the vicinity of Vananda, $29 \mathrm{~km}$ northwest of Forsyth (no. 28, pl. 1). The deposit is located in both Treasure and Rosebud Counties, Mont. (Berg, 1970). Two bentonite beds (X and $\mathrm{Y}$ ) in the lower part of the Bearpaw Shale have a thickness of 0.9-1.2 $\mathrm{m}$ and are separated by about $3 \mathrm{~m}$ of montmorillonitic shale. The Hallett Minerals Company mined bentonite in this area, during the late 1960 's and early 1970's, and processed it in a portable kiln for use as a binder in pelletizing iron ore. Both bentonite beds are underlain by a layer of hard shale several inches thick and are overlain by montmorillonitic shale. The lower contact is typically sharp, and the upper contact is gradational. Bed X ranges in thickness from 0.9 to $1.2 \mathrm{~m}$ and is pale olive when fresh and light gray on exposed surfaces. Bed Y is $76-107 \mathrm{~cm}$ thick and greenish yellow on fresh surfaces.

\section{BENTONITE RESOURCES}

We believe that there is at least 1 to $4 \mathrm{Gt}$ of bentonite resources in Montana. This includes all grades of benton- 
ite, but the resources of very high grade sodiumbentonite are probably only 100-200 Mt.

We are aware of only a very few estimates have been made on the resources of bentonite in Montana. In 1952, Patterson estimated the bentonite resources in the Hardin district to be $99.792 \mathrm{Mt}$ (Knechtel and Patterson, 1956, p. 48). In the same year, Patterson also estimated the Clay Spur Bentonite Bed and F bentonite bed in Carter County, Mont. (northern part of the Black Hills district), to contain more than 16.3 Mt (S.H. Patterson, written commun., 1956). Both of these estimates were for bentonite containing approximately 30 percent water and under less than $10 \mathrm{~m}$ of overburden. Regis and Montgomery (1979, table 2) published resource estimates for bentonite on mining claims and leases in Montana. They gave accuracy estimates of low, middle, and high for the amount of bentonite in place, containing approximately 30 percent water and under less than $22.9 \mathrm{~m}$ of overburden, and for the amount of bentonite that would be processed. Their estimates, in million metric tons are as follows:

\begin{tabular}{|c|c|c|c|}
\hline & High & $\underline{\text { Middle }}$ & $\underline{\text { Low }}$ \\
\hline Bentonite in place & 472 & 378 & 295 \\
\hline Bentonite processed & 373 & 340 & 233 \\
\hline
\end{tabular}

Ampian (1985, p. 158) published an estimate of $272 \mathrm{Mt}$ for total bentonite in Montana. His estimate was not restricted to thickness of the bentonite bed, overburden limitations, or process basis.

We believe that the bentonite resources of Montana are much larger than the $272 \mathrm{Mt}$ estimated by Ampian (1985) or the $472 \mathrm{Mt}$ estimated by Regis and Montgomery (1979). There are large deposits of bentonite in Montana that are not included in the areas of mining claims and leases such as the deposits within the Crow Indian Agency of the Hardin district (Knechtel and Patterson, 1956).

\section{NEVADA}

Nevada has had a small intermittent production of bentonite for many years, and hectorite, a variety of bentonite, was produced near McDermitt in 1992. The first production of bentonite was in 1918 (Middleton, 1921, p. 135). Most of the bentonite produced in Nevada has come from the Ash Meadows district in Nye County. Smaller bentonite deposits that were mined in 1988 (Fleming and Jones, 1989) are the Beatty deposit, Nye County; the Blanco deposit, Esmeralda County; and the Bluff deposit, Pershing County. Bentonite deposits that had no production in 1988 but have been mined in the past (Papke, 1970) are the Rosebud Canyon deposit, Pershing County; the Jupiter deposit, Lyon County; the
Walker Lake and Sodaville deposits, Mineral County; the Huntington Creek deposit, Elko County; and the Castle Mountain and Vanderbilt deposits, Clark County.

In 1970, Papke (1970, p. 1) estimated that a total of 243,000 $t$ of fuller's earth had been produced from Ash Meadows and a total of 56,000 $t$ of bentonite had been produced from all of the other deposits. By 1990, the total production of fuller's earth in Nevada may be about $500,000 \mathrm{t}$, and the total production of bentonite may be about $120,000 \mathrm{t}$. There may be as much as 2-3 Mt of bentonite resources in Nevada.

Four genetic types of bentonite deposits occur in Nevada (Papke, 1970, p.13): (1) deposits formed by the alteration of volcanic ash in alkaline lakes; (2) deposits formed from altered volcanic ash accumulations that were transported and redeposited; (3) deposits formed by alteration of host rock, including volcanic ash, by hydrothermal solutions related to magmatic activity; and (4) deposits formed by the alteration of volcanic rocks by ground-water movement.

\section{MCDERMITT HECTORITE}

The McDermitt hectorite deposits occur in a caldera complex located astride the Nevada-Oregon boundary about $20 \mathrm{mi}$ west of the town of McDermitt, Nev., (Odom, 1992, p. 586). The hectorite clay in these deposits is part of hydrothermally altered volcanic sediments filling a large caldera. In 1992, the hectorite was mined at Disaster Peak and Montana Mountains that are located in the western part of the caldera. The McDermitt hectorite is generally similar for the hectorite at Hector, Calif., but contains slightly more lethium. The McDermitt hectorite is processed to form several varieties of organophilic clay and other clays for special applications.

\section{ASH MEADOWS DEPOSITS}

The Ash Meadows deposits are within the Amargosa (River) district (see section on California), Inyo County, Calif., and Nye County, Nev. Bentonite production from this area and from the adjacent area in California has been fairly steady since 1918 (Karl, 1951, p. 15), and, according to Papke (1970), these deposits have produced the largest amount of bentonite in Nevada. Active bentonite pits at Ash Meadows, operated by Industrial Mineral Ventures, Inc., are located in sec. 29, T. $16 \mathrm{~S}$., R. 50 E., and in sec. 35 , T. 17 S., R. 51 E., to the east of the Amargosa River, Nye County (no. 56, pl. 1).

The bentonite occurs in Pleistocene and Holocene playa lake sediments (Denny and Drewes, 1965, p. L33) as irregular masses and lenses in weakly to firmly cemented white silty clay to fine-grained sand that is usually massive. It is pale yellow to pale olive and contains many small white nodules of unidentified evap- 
orate minerals. The bentonite mined is as much as $7.3 \mathrm{~m}$ thick, but the average thickness is more nearly $0.6-0.9$ $\mathrm{m}$, and the overburden is $3-8 \mathrm{~m}$ thick. Bentonite deposits in the Ash Meadows area consist of altered volcanic ash transported and redeposited in lakes.

The dominant clay mineral in the Ash Meadow bentonite is saponite, and some montmorillonite bentonite occurs on the eastern side of the Ash Meadows area. The saponite-type bentonite from this area, which does not need to be acid activated, is used primarily as a fuller's earth to decolorize and filter oil. The montmorillonitetype bentonite, which has good swelling characteristics and high plastic viscosity, requires acid activation to improve its bleaching properties. Bentonite from these deposits has also been used in drilling mud.

\section{BEATTY DEPOSIT}

The Beatty deposit (no. 55, pl. 1), is near the town of Beatty, Nye County, and includes the Roswell deposit and the New Discovery Mine of Papke (1970, p. 28-30). In 1989 , bentonite was mined in secs. 13 and 24, T. 12 S., R. 46 E. and secs. 18 and 19 T. 12 S., R. 47 E. (Fleming and Jones, 1989, p. 41). The bentonite was formed by the hydrothermal alteration of densely welded tuff in a Miocene and Pliocene ash-flow sequence of the Bullfrog Hill caldera (Cornwall and Kleinhampl, 1964). The clay bodies vary considerably in size and shape. In places, the contact of the bentonite with the unaltered tuff is sharp, but elsewhere the contact is gradational. The bentonite occurs as steeply dipping bodies in a zone that was intensely fractured and faulted and apparently resulted from the activity of hydrothermal solutions migrating through a permeable zone.

The best grade bentonite is waxy, soft, and white, with scattered pink or tan spots. The original unaltered rock had abundant phenocrysts of quartz, sanidine, oligoclase, and biotite, and these are still present in the bentonite. X-ray diffraction analysis shows that the bentonite, both the white and pink, is almost pure montmorillonite. These deposits have been mined by Vanderbilt Minerals Company, and the bentonite is processed for use as a filler and as a thickening agent in pharmaceutical and cosmetic products (Castor, 1989).

\section{BLANCO DEPOSIT}

The Blanco bentonite deposit (no. 54, pl. 1) is on the northeast side of the Silver Peak Range about $5 \mathrm{~km}$ southeast of Emigrant Peak in sec. 22, T. 1 N., R. 37 E. (Fleming and Jones, 1989, p. 34), Esmeralda County. It is in the lower part of the Esmeralda Formation (Papke, 1970, p. 20) of late Miocene or early Pliocene age (Albers and Stewart, 1965). The bentonite was formed from the alteration of ash-flow tuff by hydrothermal solutions that may have been related to a northeast-trending fault (Albers and Stewart, 1972, p. 61). It occurs in a sequence of tuffs, tuffaceous siltstones, and shales. The bentonite is predominantly white to very light gray montmorillonite having a very small amount of chlorite and illite. Cristobalite, potassium feldspar, plagioclase, and quartz are present in small amounts. The clay has been used as a suspending agent for solid particles in a liquid medium.

\section{BLUFF DEPOSIT}

The Bluff bentonite deposit (no. 50, pl. 1), in secs. 2 and 11, T. 27 N., R. 32 E., and secs. 6 and 8, T. 27 N., R. 33 E., Pershing County, is in the Willard mining district of Johnson (1977, p. 102). The deposit occurs both north and south of the Coal Canyon Road about $10 \mathrm{~km}$ northeast of Lovelock. The bentonite was formed by intense hydrothermal alteration of vitric and tuffaceous rocks in a sequence of Oligocene volcanic rocks. It consists of white to light-gray montmorillonite; cristobalite, quartz, and potassium feldspar are the principal contaminants. Traces of plagioclase, calcite, gypsum, and zeolite are also present in varying amounts. The swelling property of this clay varies; however, the bentonite from sections 6 and 11 had the highest and most consistent swelling characteristics. Only a small amount of clay has been removed from these deposits.

\section{ROSEBUD CANYON DEPOSIT}

The Rosebud Canyon bentonite deposit (no. 49, pl. 1) is in sec. 33 or 34 , T. 34 N., R. 29 E., Pershing County, in a sequence of lacustrine Miocene and Pliocene silts and clays. The bentonite consists of a bed of white to yellowish-white montmorillonite having a maximum thickness of $1.2 \mathrm{~m}$. It was formed by the diagenetic alteration of glassy volcanic ash. No production records are available, but during the mid-1930's several carloads were shipped to California (Papke, 1970, p. 34).

\section{JUPITER DEPOSIT}

The Jupiter bentonite deposit (no. 51, pl. 1), in sec. 12, T.16 N., R. 24 E., Lyon County, is on the west side of highway U.S. 95 about $4 \mathrm{~km}$ south of Weeks. The bentonite has been mined intermittently since 1936 by the Minor Minerals Company for use as a fuller's earth for decolorizing oils, as a carrier for pesticides, and as a binder in animal feed pellets. The total thickness of the bentonite is unknown, but a measured section by Papke $(1970$, p. 23) shows a minimum thickness of $6 \mathrm{~m}$. According to Archibold (1969, p.40), the bentonite was formed by the hydrothermal alteration of volcanic rocks, and it is interbedded with Miocene and Pliocene medium-gray andesite porphyry. X-ray diffraction analysis indicates 
that the clay minerals montmorillonite, kaolinite, and chlorite are associated with abundant gypsum and lesser amounts of quartz, cristobalite, and feldspar.

\section{WALKER LAKE DEPOSITS}

The Walker Lake deposits (no. 52, pl. 1) include the Snowflake and Chiatovich deposits of Archibold (1966, p. 3 ), which are on the east side of Walker Lake approximately $15 \mathrm{~km}$ due north of Hawthorne, Mineral County. The Chiatovich property is in sec. 24 , T. 9 N., R. $30 \mathrm{E}$., and the Snowflake property is in parts of secs. 2, 3, 10, and 11 , T. 9 N., R. 30 E. Bentonite was produced from the Chiatovich property in the 1950's for sealing reservoirs, but no bentonite production has been recorded for the Snow-fake property.

The bentonite, composed predominantly of montmorillonite, is a layer about $6 \mathrm{~m}$ thick in the Esmeralda Formation of late Miocene to early Pliocene age (Ross, 1961, p. 46). Siltstone beds overlie the bentonite bed, and the underlying beds are silty claystone, claystone, and fine-grained conglomerate. The clay is pale orange, containing a few sand layers and locally small amounts of volcanic glass and diatoms. Papke (1970, p. 24) and Archibold $(1966$, p. 4) stated that some of the bentonite has good swelling properties. The bentonite was believed to have formed by the diagenetic alteration of impure volcanic ash.

\section{SODAVILLE DEPOSIT}

The Sodaville deposit (no. 53, pl. 1), in sec. 31 , T. 6 N., R. $35 \mathrm{E}$., is the eastern end of the Excelsior Mountains and a little over $2 \mathrm{~km}$ west of Sodaville, Mineral County. Bentonite from this deposit was shipped to California during the late 1920's and early 1930's for use in drilling mud and for sealing portions of the Owens Valley aqueduct.

The oldest rocks are rhyolitic tuffs, tuff-breccias, and andesitic flows of Miocene or Pliocene age. Andesitic flows unconformably overlie the rhyolitic rocks. The bentonite was formed by hydrothermal solutions that moved through a major faulted and brecciated zone in the rhyolite volcanic rocks and was partly trapped by the andesitic flows. As a result, two types of bentonite are present. The first type is a very pale orange to almost white bentonite derived from the rhyolite volcanic rocks, and the second type is reddish-brown bentonite derived from the lower part of the andesitic flows. Varying amounts of quartz, cristobalite, and potassium feldspar are present. The physical properties of the bentonite are variable, but one sample shows superior swelling and viscosity properties (Papke, 1970, p. 26).

\section{HUNTINGTON CREEK DEPOSIT}

The Huntington Creek deposit (no. 48, pl. 1), in sec. 18, T. 31 N., R. 56 E., is on Huntington Creek about 28 $\mathrm{km}$ south of Elko, Elko County. The bentonite occurs as a bed in a sequence of sedimentary clayey siltstone to very coarse arkosic sandstone and interbedded volcanic tuff and ash-bed rocks that are a part of the Miocene Humboldt Formation (Coats, 1987, p. 62). The bentonite bed, a few centimeters to $0.6 \mathrm{~m}$ thick, consists of an upper unit of almost white pure montmorillonite and a lower unit of light-brown impure montmorillonite containing considerable quartz sand and pebbles. The bentonite was formed by the diagenetic alteration of volcanic ash beds. Several carloads of clay were shipped to California in 1927. Although good-quality bentonite may be present (one sample test had good physical properties), the bed is too thin for major commercial development (Papke, 1970, p. 19).

\section{CASTLE MOUNTAIN DEPOSIT}

The Castle Mountain deposit (no. 58, pl. 1), in sec. 5, T. $30 \mathrm{~S}$, R. $62 \mathrm{E}$., is near the north end of the Castle Mountain about $18 \mathrm{~km}$ southwest of Searchlight, Clark County. The northern part of the Castle Mountains is underlain by Tertiary volcanic rocks consisting of glassy flows, pyroclastic rocks, and massive pumice (Longwell and others, 1965). The pumice, probably a shallow intrusive-extrusive body, is the host rock for the bentonite. The bentonite was probably formed by the chemical action of ground water altering the volcanic rocks to bentonite. It is composed predominantly of pale-pink to white and slightly waxy montmorillonite and is reported to have been mined for use in the pharmaceutical industry.

\section{VANDERBILT DEPOSIT}

The Vanderbilt bentonite deposit (no. 57, pl. 1), in sec. 28, T 19 S., R. 64 E., is in the Gale Hills near the southwest end of the Muddy Mountains $28 \mathrm{~km}$ northnortheast of Las Vegas, Clark County. The deposit is in the Gale Hills Formation of Cretaceous(?) or Tertiary(?) age (Longwell and others, 1965); the deposit consists of a sequence of siltstones, claystones, and some thin- to medium-bedded limestones. The bentonite occurs as a bed having gypsum crystals concentrated in its lower part and is in sharp contact with the underlying limestone unit. The bentonite, light olive in color, is composed of montmorillonite with a small amount of illite and mixed-layer clay and is 0.6 to $0.9 \mathrm{~m}$ in thickness. The bed is overlain by a $1-\mathrm{m}$ unit of reddish-brown silty clay ( 23 $\mathrm{cm})$ and massive white to pink limestone $(76 \mathrm{~cm})$. This bentonite was formerly mined for use as a thixotropic 
agent, which when mixed with water forms a gel when undisturbed but becomes a liquid when stirred or shaken.

\section{OTHER DEPOSITS}

Papke (1970) has listed 12 additional deposits in Nevada that have had no bentonite production but are listed as prospects or occurrences. They are as follows: (1) Trinity deposit, secs. 7 and 8, T. 23 N., R. 27 E., and (2) Lahontan deposit, secs. 16 and 17, T. 18 N., R. 26 E., Churchill County; (3) Willow Tank deposit, sec. 11, T. 17 S., R. 67 E., Clark County; (4) Barret Springs deposit, sec. 34 , T. 37 N., R. 36 E., Humbolt County; (5) Bristol deposits, sec. 29 , T. 3 N., R. 65 E., and sec. 31 , T. 3 N., R. 66 E., Lincoln County; (6) Broken Hill deposit, sec. 21, T. 14 N., R. 35 E., (7) Mina deposit, sec. 10, T. 6 N., R. 35 E., and (8) Rhodes Marsh deposit, sec. 6, T. 4 N., R 36 E., Mineral County; (9) Pahute Mesa deposit, sec. 11, T. 7 S., R. 44 E., and (10) Sarcobatus Flat deposit, secs. 30 and 31, T. 7 S., R. 45 E., Nye County; (11) San Emidio deposit, secs. 27 and 34, T. 30 N., R. 23 E., and (12) Nixon deposit, sec. 34, T. 24 N., R. 23 E., Washoe County.

\section{NEW MEXICO}

Bentonite occurs in many places throughout New Mexico, but it has been mined only on a small scale at a few localities (Reynolds, 1952). A plant, built at Hatch (no. 42, pl. 1) in the 1930 's, processed bentonite for drilling mud until the early 1940 's. The clay was mined in sec. 30 , T. 19 S., R. 4 W., $4.8 \mathrm{~km}$ north of State highway 26 , near the western boundary of Dona Ana County (Patterson and Holmes, 1965, p. 314). The bentonite is from the Santa Fe Group of Miocene to Pleistocene(?) age. According to testing by Reynolds (1952, p. 25), the properties of this bentonite are inferior to those from Wyoming for use in drilling mud, but according to Nutting (1943, p. 151), a sample from near Hatch had excellent oil-bleaching properties after acid treatment.

A large undeveloped bentonite deposit, approximately $40 \mathrm{~km}$ north of Socorro, is also in the Santa Fe Group of Miocene to Pleistocene(?) age. According to Reynolds (1952, p. 25), this deposit is extensive. Patterson and Holmes (1965, p. 314) reported bentonite from this deposit to be variable in quality.

Scattered large deposits of impure bentonite beds of Cretaceous age occur in southwestern San Juan and northwestern McKinley Counties (Allen, 1955). According to the few tests that have been made, the physical properties of these bentonites for drilling mud and sand bonding are too poor to compete with high-grade bentonite from other sources (Patterson and Holmes, 1965, p. 316).

\section{NORTH DAKOTA}

Along the Pembina escarpment, western Grand Forks County (Hansen and Kume, 1970, p. 63), west-central Walsh County (Bluemle, 1973, p. 55), and Cavalier and Pembina Counties (Arndt, 1975, p. 33), beds of bentonitic clay occur in the basal Pembina Member of the Pierre Formation. The clay is the calcium and magnesium type and may be usable as fuller's earth. In Grand Forks and Walsh Counties, this clay is in beds ranging from less than a centimeter to about $30 \mathrm{~cm}$ in thickness. In Cavalier and Pembina Counties, the clay does not seem to be abundant enough or high quality enough to be considered for commercial uses. The nearest bentonite mining operation is north of the International line along the same escarpment at Morden, Manitoba. The bentonite is being used for clarifying mineral, vegetable, and animal oil and as a binder for taconite iron ore.

\section{OKLAHOMA}

Many small bentonitic clay deposits are associated with Tertiary and Pleistocene volcanic ash deposits in northwestern Oklahoma (Johnson, 1969). From a pit about $8 \mathrm{~km}$ south-southeast of Vici and $2.4 \mathrm{~km}$ east of State road 34 in E⿺𠃊2, sec. 29, T. 19 N., R 19 W., Dewey County (no. 20, pl. 1), a few hundred metric tons of bentonite were mined during the 1970's and 1980's. The bentonite is probably in the Ogallala Formation of Miocene age. It is almost white and is approximately $1 \mathrm{~m}$ thick. During the 1980 's, a few metric tons of bentonite were trucked to America Colloid Company's plant in Mississippi for processing as a fuller's earth.

\section{OREGON}

Two companies, Central Oregon Bentonite Co., and Teague Mineral Products, produced bentonite in Oregon in 1989 (Gray and others, 1989; Gray, 1990). Central Oregon Bentonite Company started producing bentonite in 1958, and Teague Mineral Products started producing bentonite in 1974 .

The plant and nearby pits of the Central Oregon Bentonite Co., are located about $38 \mathrm{~km}$ northeast of Brothers, Crook County (no. 47, pl. 1). This company has produced bentonite for use as an absorbent in cat litter, as a binder in animal feed, and as a sealant for ditches and ponds. The bentonite is mined from a 0.9- to 1.2$\mathrm{m}$-thick bed in the John Day Formation of Eocene to 
Miocene age, which is composed of variegated fine- to medium-grained tuffaceous sedimentary rocks. Volcanic glass in these rocks has been altered to zeolites and bentonite and associated small amounts of opal, orthoclase, and calcite.

The plant for the Teague Mineral Products is located near Adrian, Malheur County (no. 46, pl. 1), and the pits are located $20-24 \mathrm{~km}$ south of the plant. This company has produced bentonite as a sealant for sewage lagoons and at hazardous waste sites, as a binder in animal feed, and as mud for drilling water wells. The bentonite beds mined by Teague are in the Miocene Sucker (Succor) Creek Formation of Corcoran and others (1962). This formation is a drab-colored nonindurated series of volcanic tuffs and tuffaceous lacustrine clastic sediments having a pale-yellow, greenish-orange, to dark yellowishbrown color. Bentonite was formed by the weathering of the predominant platy shales, massive siltstones, and claystones of the formation. Selenite crystals are quite abundant on exposed weathered surfaces. The lithologic units are local in extent because of the lacustrine and fluvial origin. The older and main bentonite bed averages about $6 \mathrm{~m}$ in thickness, and the younger bed averages about $9 \mathrm{~m}$ in thickness. The bentonite (table 1 , map no. 46) is light olive green to very light gray and contains more than 95 percent smectite; grains of quartz, feldspar, and mica make up the balance (Leppert, 1985).

\section{SOUTH CAROLINA}

A bentonitic clay bed, mined at a locality $1.5 \mathrm{~km}$ northwest of Rimini, Sumter County (no. 2, pl. 1), is in the Black Mingo Formation of Paleocene age (Colquhoun and others, 1969). A pit operated by the SCA Services, Inc., yields clay used primarily as an absorbent (Hosterman, 1985). The bed is about $15 \mathrm{~m}$ thick, but only $11 \mathrm{~m}$ of clay is removed by the mining operation because, after the bentonitic clay is removed, the pit is used for storing chemical waste products that are covered by some of the removed bentonitic clay. The clay at this locality is composed predominantly of montmorillonite that was probably from volcanic ash being deposited in a marine environment. Elsewhere on the South Carolina Coastal Plain, montmorillonite in the Black Mingo Formation is replaced by opaline cristobalite (Heron and others, 1965, p. 19).

A unique deposit of nonswelling bentonite is in the Hawthorne Formation (Heron and others, 1965, p. 24), Jasper County, located $4 \mathrm{~km}$ south-southeast of Coosawhatchie. Called the Coosawhatchie clay, it is in a bed up to $6 \mathrm{~m}$ thick and extends over hundreds of square kilometers. According to Heron and others (1965), the clay is predominantly montmorillonite with $15-20$ percent illite and a trace of kaolinite. Attapulgite has been identified in some samples. Robinson and others (1961, p. 3) reported the potential uses of this bentonite to be drilling mud, foundry bonding, oil clarification, filler, binder, and plasticizer.

\section{SOUTH DAKOTA}

Bentonite mining in South Dakota began in 1915 when clay beds in the lower part of the Pierre Shale were mined near Buffalo Gap, Custer County (Connolly and O'Harra, 1929, p. 326). However, mining of these bentonite beds lasted only $2 \mathrm{yr}$, and only about $300 \mathrm{t}$ of clay were removed (Patterson and Harksen, 1975, p. 127). Mining of calcium-bentonite near Ardmore, Fall River County (no. 23, pl. 1), for use as a water softener (Spivey, 1940, p. 1), began in 1917 and continued intermittently for several years.

The Ardmore bentonite occurs at the base of the Sharon Springs Member of the Pierre Shale of Late Cretaceous age. The bed has a thickness of about $1.5 \mathrm{~m}$ and consists of light-yellow clay containing minor amounts of interbedded black shale (Connor, 1963, p. 122). It crops out intermittently for about $160 \mathrm{~km}$ along the south and southeast sides of the Black Hills. The Ardmore bed, which also is Bed I of Knechtel and Patterson (1962, p. 990-994), crops out in a broad area north of the town of Belle Fourche, S. Dak. A sample of this bentonite bed tested very high for green foundrysand bond (Knechtel and Patterson, 1962, table 4). The geology of Bed I is discussed further on page 38 .

During the 1930's and 1940's, South Dakota ranked with the leading States in bentonite production. During that period, bentonite was mined throughout a belt extending from Belle Fourche westward to Crook County, Wyo. Bentonite reserves in the Clay Spur bed in South Dakota were depleted in the 1950's, and later mining shifted to Crook County, Wyo. The geology of the Clay Spur bed is outlined in the discussions of its occurrences in Crook County, Wyo.

\section{TENNESSEE}

The early Paleocene Porters Creek Clay of the Midway Group (figs. 9,10 ) occurs in a narrow north-south belt 1.6-13 km wide across Henry, Carroll, Madison, Henderson, Chester, and Hardeman Counties (Whitlatch, 1940, p. 52). The clay is dark gray to almost black when wet and light gray to almost white when dry. Whitlatch (1940, p. 188-200), who tested the Porters Creek Clay for oil-bleaching possibilities, concluded that on the basis of decolorizing activity, these clays could compete with commercial fuller's earth products from other areas. Fuller's earth is currently (1990) produced by Lowe's 
Southern Clay, Inc., from a clay pit $5 \mathrm{~km}$ south of Paris, Henry County (no. 12, pl. 1). The clay is processed as an industrial and pet-waste absorbent and as an insecticide and fungicide carrier. Based on one sample from the pit, the clay contains only trace amounts of nonclay minerals. The clay is bentonitic, containing 50 percent montmorillonite, 25 percent illite, and 25 percent kaolinite (Hosterman, 1984, p. C16). Based on the length of the outcrop belt of the Porters Creek Clay and the thickness of the bentonite unit, the fuller's earth resources in Tennessee are probably on the order of several billion metric tons (Gt).

\section{TEXAS}

The bentonite deposits in Texas occur in three areasnear Lufkin, at Riverside, and in the vicinity of Gonzales and Flatonia. Most of the active bentonite deposits are in the sedimentary rocks of the Claiborne and Jackson Groups; one active deposit is in the Catahoula Formation (fig. 10) (Hosterman, 1984, p. C13). The bentonite occurs as massively bedded lens-shaped bodies with interbedded beds of gravel, sand, silt, and limestone or marl. The bentonite beds range from 1 to $6 \mathrm{~m}$ thick, and the minable deposits have an areal extent of approximately 135 by $225 \mathrm{~m}$ to 1,000 by $1,200 \mathrm{~m}$. The overburden is less than 10 $m$ thick. The dry bentonite ranges from medium gray to white, but pale-brown, yellowish-gray, and brownishgray colors are also quite common. Bentonite beds in the Claiborne Group (lower and middle Eocene) and the Jackson Group (upper Eocene) contain 90-100 percent montmorillonite. Quartz is the major nonclay mineral; plagioclase and heulandite are found in minor to trace amounts, and feldspar, biotite, and muscovite are found in trace amounts.

No published estimates exist on the bentonite resources of Texas. Based on the areal extent of the formations in the Claiborne and Jackson Groups-formations that contain the best grade bentonite beds, the resources of calcium-bentonite in the Texas Gulf coastal area are probably as much as $1 \mathrm{Gt}$.

\section{LUFKIN DEPOSITS}

An old bentonite pit $11.5 \mathrm{~km}$ northeast of Lufkin, Angelina County (no. 17, pl. 1) exposes a bed of mediumgray bentonite in the Yegua Formation, the upper formation of the Claiborne Group (fig. 10). This mine, which is no longer in operation, reported produced bentonite that was activated by acid treatment to improve its bleaching properties (Fisher, 1965, p. 165). A sample from the pit proved to contain 95 percent clay and 5 percent sand and silt. The clay fraction is composed of 100 percent montmorillonite. A test pit, $3.2 \mathrm{~km}$ north of
Redland and $11.5 \mathrm{~km}$ north of Lufkin, contained $5.5 \mathrm{~m}$ of light-brown bentonite (Johnson, 1937). Another undeveloped bentonite deposit, $5.6 \mathrm{~km}$ south of Forest, Cherokee County, $31 \mathrm{~km}$ northwest of Lufkin, contains a 3-mthick bluish-gray bentonite having very little sand or silt (table 1, map no. 17). Both of these bentonite occurrences are in the Eocene Cook Mountain Formation of the Claiborne Group (Texas University, 1967).

\section{RIVERSIDE DEPOSIT}

Bentonite in a pit $1.5 \mathrm{~km}$ west of Riverside and $19 \mathrm{~km}$ northwest of Huntsville, Walker County (no. 18, pl. 1), is actively being mined by the Milwhite Company, Inc. The bentonite is light gray and occurs in a bed 1.5-4 m thick. It contains less than 3 percent sand- and silt-sized quartz and biotite. Three samples averaged 61 percent montmorillonite, 7 percent illite, 30 percent kaolinite, and a trace of illite-smectite mixed layer (table 1, map no. 18). This bentonite is in the Catahoula Formation of Miocene age (Texas University, 1968) and has been used in drilling mud and as a binder.

\section{GONZALES-FLATONIA DISTRICT}

The Gonzales-Flatonia bentonite district is approximately $10-13 \mathrm{~km}$ wide and $54 \mathrm{~km}$ long, extending in a northeast direction from $10 \mathrm{~km}$ east of Gonzales, Gonzales County, to $15 \mathrm{~km}$ north of Flatonia, Fayette County (no. 19, pl. 1). The bentonite beds, in this district, are chiefly in the Yegua Formation of the Claiborne Group and the Caddell Formation of the Jackson Group (fig. 10) (Chelf, 1942; Dietrich and Lonsdale, 1958, p. 16-17; Texas University, 1974); both beds are of Eocene age.

The bentonite bed in the Yegua Formation, which is mined by the Southern Clay Products, Inc., is exposed in a pit about $8 \mathrm{~km}$ east of Gonzales. A total of $4.3 \mathrm{~m}$ of bentonite is in three units (table 1, samples 44-46-JH-81): a lower 2.4-m unit of pure white bentonite composed of montmorillonite with only a trace of sand and silt; a middle 1.1-m unit of very light greenish gray bentonite composed of 4 percent sand, 52 percent silt, and 44 percent clay, the clay fraction containing equal amounts of montmorillonite and kaolinite; and an upper $0.8-\mathrm{m}$ unit of 100 percent white montmorillonite with some black manganese staining. The bentonite has been used for drilling mud and as a binder.

An abandoned pit $8.5 \mathrm{~km}$ southeast of Waelder, Gonzales County, exposes a 1-m-thick bentonite bed in the Caddell Formation of the Jackson Group, and the bentonite is a waxy brownish-gray clay (Maxwell, 1962, p. 52) that contains about 6 percent sand, 2 percent silt, and 92 percent clay (table 1 , sample $46-\mathrm{JH}-81$ ). The only mineral in the clay fraction is montmorillonite (Hoster- 
man, 1984, p. C16-C17). This clay was probably used for drilling mud and as a bond for foundry sand.

The Balcones Mineral Corporation's bentonite pit, 2.5 km west of Flatonia, Fayette County, exposes a 3$\mathrm{m}$-thick bentonite bed in the Manning Formation, Jackson Group (Texas University, 1974). The bentonite is brownish pink and, based on one sample, consists of 96 percent clay and 4 percent sand and silt (table 1 , sample 48-JH-81). The clay fraction is 90 percent montmorillonite and 10 percent kaolinite. Quartz is the only nonclay mineral. This bentonite is used for drilling mud.

The Milwhite Company, Inc., operates a bentonite pit $4 \mathrm{~km}$ northwest of Muldoon, which is $14.5 \mathrm{~km}$ north of Flatonia, Fayette County. Medium-gray bentonite in this pit is approximately $2.5 \mathrm{~m}$ thick. It is in the Caddell Formation of the Jackson Group and, based on one sample, consists of 94 percent clay and 6 percent sand and silt (table 1, sample 43-JH-81). The clay-size fraction is montmorillonite and a trace of illite and kaolinite. The bentonite is being used for drilling mud and as a binder.

An abandoned pit, approximately $5 \mathrm{~km}$ north of Muldoon, exposes yellowish-gray bentonite consisting of about 95 percent montmorillonite and 5 percent illite. The clay is very sandy having quartz and plagioclase as the nonclay minerals (table 1 , sample 42-JH-81). Traces of muscovite and the zeolite, heulandite, were identified by X-ray diffraction methods.

\section{OTHER DEPOSITS}

Hosterman (1984, p. C18-C19) and Maxwell (1962, p. $50-68$ ) list 20 additional bentonitic clay occurrences in the Gulf of Mexico Coastal Plain of Texas. Although the clay at most of these localities is predominantly montmorillonite, kaolinite is also present, and some also contain illite. In addition, most of the samples from these localities that have been analyzed contain a high percentage of sand and silt. One sample of bentonite from a roadcut on State road 649, in Jim Hogg County, $26.5 \mathrm{~km}$ southsoutheast of Miranda City contains 95 percent clay, a trace of sand, and 5 percent silt. The clay fraction is 100 percent montmorillonite. This bentonite occurs in an area that is mapped as Catahoula and Frio Formations, undivided (Texas University, 1976).

\section{UTAH}

Deposits of bentonitic clay occur at several localities in Utah. The three most productive deposits, in recent years, are Redmond Hills, Aurora, and Tropic. Bentonite has been mined intermittently by the Redmond Clay and Salt Company from four pits in secs. 13 and 24, T. 20 S., R. 1 W., in the Redmond Hills, Sanpete County, about $6.5 \mathrm{~km}$ north of Redmond (no. 59, pl. 1). The bentonite has been used locally as lining for irrigation ditches and stock ponds. The bentonite occurs interbedded with pyroclastic material of the Gray Gulch Formation(?) of Oligocene age (Pratt and Callaghan, 1970, p. 53). The bentonite consists of montmorillonite having small amounts of quartz grains and biotite flakes.

Two active pits belonging to the Western Clay Company are in the Aurora area of Sevier County-one in sec. 2 and one in sec. 31 , T. 21 S., R. 1 W (no. 60, pl. 1). The pit in sec. 2 is $1.5 \mathrm{~km}$ west of Redmond and $10.5 \mathrm{~km}$ north-northeast of Aurora, and the pit in sec. 31 is $2 \mathrm{~km}$ northwest of Aurora. According to Hall and Starkey $(1985$, p. 28$)$, the bentonite from these pits is used as a fuller's earth for bleaching, clarifying, and filtering oil, jet fuel, and beverages. The bentonite consists chiefly of montmorillonite with traces of calcite, dolomite, quartz, feldspar, mica, and cristobalite. It probably is in the Gray Gulch Formation, of Oligocene age, and was formed by weathering alteration of pyroclastic volcanic debris.

A bentonite deposit $3 \mathrm{~km}$ south-southeast of Tropic, Garfield County (no. 61, pl. 1), was mined for use at the Glen Canyon Dam project (Robison, 1966, p. 44). A pit in sec. 13, T. 37 S., R. 3 W., exposes a bentonite bed $3.4 \mathrm{~m}$ thick at the base of the Cretaceous Dakota Formation. The bentonite was also used as a drilling mud and for sealing canals and for bonding foundry sand (Doelling, 1975, p. 152).

\section{VIRGINIA AND MARYLAND}

The Miocene Calvert Formation of Virginia and Maryland contains a bed of diatomaceous mudstone having the properties necessary to make an absorbent and mineral filler product (Johnson and Tyrrell, 1967, p. 173; Sweet, 1982 , p. 122-126). In Virginia, this bed is exposed at Carters Wharf, near Morattico, Richmond County, and in a pit $4.5 \mathrm{~km}$ north-northwest of Walkerton, King and Queen County (no. 1, pl. 1). The pit is owned by Bennett Mineral Co., which, in 1983, produced a clay product that was used for absorbing oil and grease (Sweet, 1983). In Maryland, the diatomaceous mudstone is exposed at three localities: (1) on the south side of the Potomac River at the mouth of Popes Creek, Charles County; (2) on the east side of the Patuxent River at Lyons Creek Wharf, Calvert County; and (3) at Fairhaven on the Chesapeake Bay, Anne Arundel County (Knechtel and Hosterman, 1965, p. D151). In Maryland, the bed is known as the Fairhaven Member of the Calvert Formation.

The mudstone is a buff to white bentonitic clay rather than a diatomaceous earth that occurs in a bed $3-5 \mathrm{~m}$ thick. A sample from the pit in King and Queen County, Va., contains about 25 percent sand and silt and 75 percent clay. The clay fraction, analyzed by X-ray dif- 


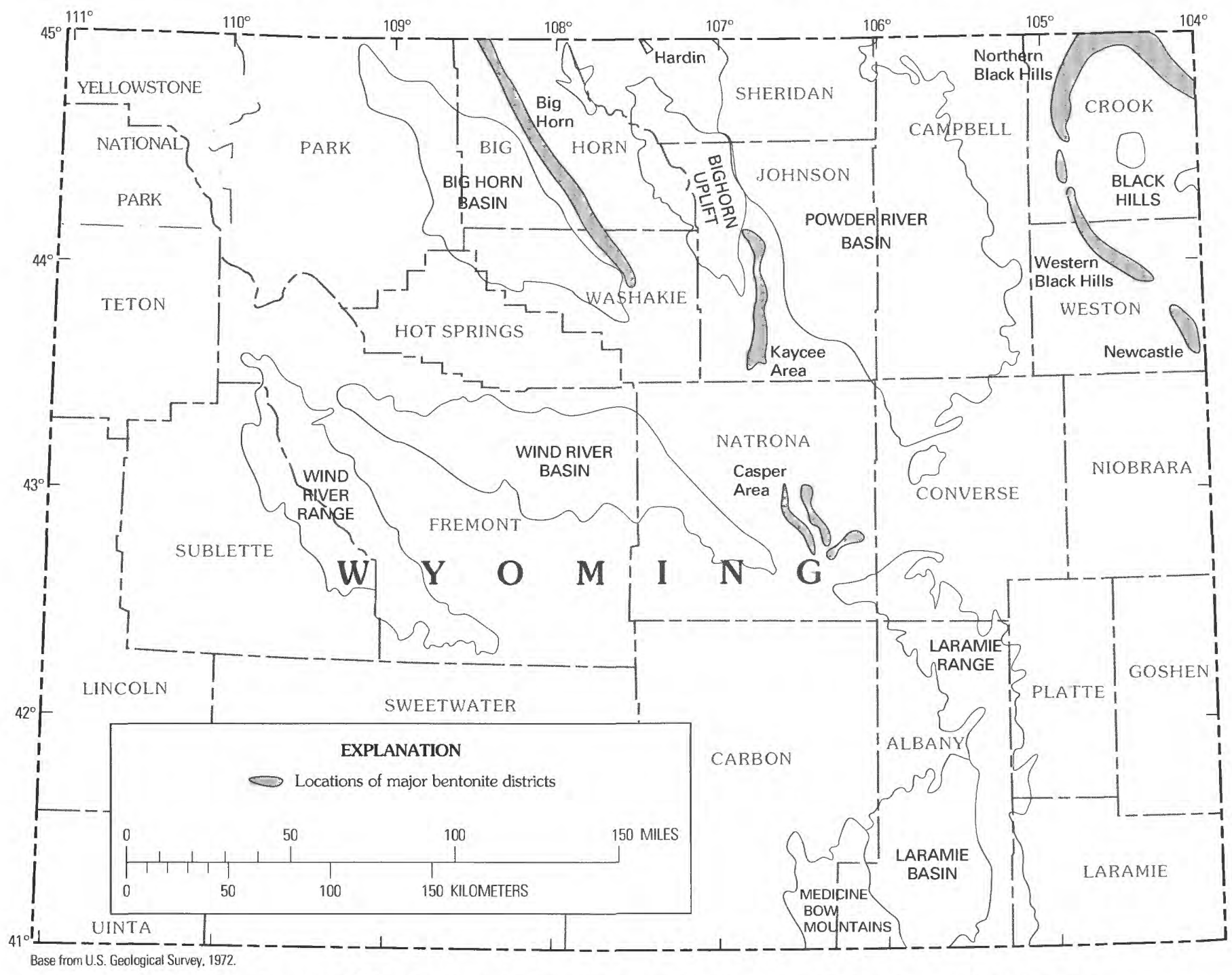

FIGURE 11. - Location of Wyoming bentonite deposits discussed in this report. Modified from Rath (1986, p. 86).

fraction, was found to be composed of approximately 45 percent montmorillonite, 35 percent illite, and 20 percent kaolinite. A sample from Fairhaven, Md., also contained 25 percent sand and 75 percent clay. The clay fraction was found to be composed of 75 percent montmorillonite, 15 percent illite, and 10 percent kaolinite.

\section{WASHINGTON}

Bentonite has been mined in small quantities from a pit near the Tieton Reservoir (E/2 sec. 7, T. 13 N., R. 14 E.) in Yakima County (Hosterman and Livingston, 1966, p. 182). It was used for sealing irrigation canals and reservoirs and as a forest-fire retardant. The bentonite formed from the alteration of volcanic ash in small lakes during the Pleistocene.

\section{WYOMING}

Bentonite deposits of economic importance in Wyoming are in Cretaceous formations exposed on the north and west flanks of the Black Hills, around the western margin of the Powder River Basin, on the eastern margin of the Big Horn Basin, in the Wind River Basin, and in the Laramie Basin (figure 11). According to Rath (1983), the bentonite beds mined in the northern and western Black Hills districts are thinner than the bentonite beds mined in the Big Horn Basin or in the western edge of the Powder River Basin at Kaycee.

\section{BLACK HILLS REGION}

The Black Hills region includes the bentonite deposits that occur in Wyoming, Montana, and South Dakota. The discussion is included under Wyoming because most of the bentonite is in Wyoming. The region may be divided 
into two districts, the Northern Black Hills district and the Western Black Hills district. The northern Black Hills district is approximately $97 \mathrm{~km}$ long and extends along the north side of the Black Hills in parts of Crook County, Wyo. (no. 31, pl. 1), Carter County, Mont. (no. 25, pl. 1), and Butte County, S. Dak. (no. 24, pl. 1). The Western Black Hills district is in parts of Crook and Weston Counties, Wyo. The Black Hills bentonite region has long been a major source of sodium-bentonite and a minor source of calcium-bentonite. Approximately 1.5 Mt are mined and processed annually from the following plants: American Colloid Company and N L Industries, Inc., at Colony, Wyo. (no. 31, pl. 1); American Colloid Company at Belle Fourche, S. Dak. (no. 24, pl. 1); and American Colloid Company at Upton, Wyo. (no. 32, pl. 1).

The bentonite beds in the entire Black Hills region occur in Cretaceous age sediments that consist chiefly of marine shales, marls, and argillaceous sandstones (Knechtel and Patterson, 1962). Bentonite has been mined from five beds found in the Newcastle Sandstone, Mowry Shale, Belle Fourche Shale, and Pierre Shale (fig. 8). Bed A, of the Newcastle Sandstone, has been surpassed only by the Clay Spur Bentonite Bed as a source of bentonite in the northern district. The Clay Spur Bentonite Bed, near the top of the Mowry Shale, was the first bed mined and has been the major source of bentonite in the entire region. Bed $\mathrm{E}$, in the lower part of the Belle Fourche Shale, is also mined in a few places, particularly in the Western Black Hills district. Bed F, in the upper part of the Belle Fourche Shale, is mined in the Montana part of the northern district by one company. Bed I, at the base of a black shale unit known as the Mitten Member of the Pierre Shale, was formerly a source of calcium-bentonite in the northern district, but it has not been mined for several years.

Bed A.-Bentonite Bed A in the Newcastle Sandstone crops out in the western part of the northern district and is also present in the western district (Davis, 1965). This bentonite forms lenticular units that vary considerably in thickness and areal extent.. Some lenses are as much as 9 $\mathrm{m}$ thick and range in lateral extent from $90 \mathrm{~m}$ to more than $1.6 \mathrm{~km}$.

Where Bed A is covered by a thick overburden, the bentonite is bluish gray, whereas at or near the surface, the bentonite ranges from olive green through shades of greenish gray to brownish gray. The color differences are probably due to the circulation of ground water through the porous sandy material overlying Bed A. This circulation of ground water has resulted in the oxidation of the iron that changes the color. In some places the bentonite adjacent to joints or other fractures in the bed is darker than normal. The darker bentonite apparently has been stained by traces of organic material.
The bentonite in Bed A contains nonclay material of various kinds. Crystals of colorless selenite (gypsum) and angular fragments of fibrous calcite are strewn on the surface of some outcrops. Individual samples of bentonite contain from 10 to 35 percent clear subangular quartz and feldspar, rounded masses of limonite, euhedral and rounded flakes of biotite, small crystals and fragments of selenite, and traces of muscovite, garnet, zircon, magnetite, glass shards, and grains of fine-grained schist. Much of the nonclay material in the bentonite is inherited from the parent volcanic ash, but most of the quartz, feldspar, grains of schist, and some of the accessory minerals that are also in the Newcastle Sandstone have been transported and deposited by streams and nearshore currents.

Clay Spur Bentonite Bed.-The Clay Spur Bentonite Bed is in the uppermost part of the Mowry Shale. It is named after the clay at the old railroad spur of the Burlington Northern, Inc. (railroad), known as the Clay Spur in the western Black Hills district. The Clay Spur Bentonite Bed has been the source of more than 80 percent of all the bentonite shipped from the Black Hills region. The bed is generally $0.6-0.9 \mathrm{~m}$ thick at most places, but it ranges from as little as $5.1 \mathrm{~cm}$ to as much as $2 \mathrm{~m}$ in thickness. Both the thick and thin parts of the bed are irregular in areal distribution, and locally thicknesses of less than $30 \mathrm{~cm}$ to more than $90 \mathrm{~cm}$ may occur within a distance of only a few tens of meters; however, such variations in thicknesses generally occur over greater distances. Where the bentonite bed is more than $30 \mathrm{~cm}$ thick, it shows a sharp contact with the dark-gray underlying cherty material. This cherty layer, generally 20-50 cm thick and considerably harder than the siliceous Mowry Shale, is believed to contain silica released during the alteration of the volcanic ash to bentonite (Knechtel and Patterson, 1962, p. 936-937). The cherty layer is generally absent where the bentonite bed is less than 30 $\mathrm{cm}$ thick. In its place is a layer of dark-gray bentonitic shale about $2.5 \mathrm{~cm}$ thick.

Undried raw Clay Spur bentonite is generally waxy, but the bentonite within 6-12 $\mathrm{mm}$ of the base has a granular texture similar to that of cornmeal and contains fragments of gypsum, small flakes of biotite, and grains of quartz and feldspar. The X-ray diffraction traces (fig. 3 and tables 2 and 3) indicate that the Clay Spur Bentonite Bed also contains minor quantities of cristobalite in addition to quartz.

Fresh bentonite under several meters of overburden is bluish gray, but where little or no overburden is present, the bentonite shows various shades of olive green due to weathering. Color changes commonly take place along joints, and, as a result, joint blocks may show discolored outer zones around subspherical cores of bluish-gray bentonite. In general, the change in color by weathering 
is accompanied with a change in the physical properties that improves the bentonite desired for some commercial uses. The discoloration is mainly the result of oxidation of the small amount of iron in the bentonite, but improvements in the physical properties are probably due to other factors. The apparent principal cause for the improved properties is the tendency for the weathered bentonite to break down more readily into fine particle sizes.

Bed E. - Bentonite Bed E, about 7.6-10.6 $\mathrm{m}$ above the base of the Belle Fourche Shale, is mined chiefly in the western Black Hills district. This bed is reported to be as much as $1.5 \mathrm{~m}$ thick (Mapel and Pillmore, 1964, p. J48), but where it was recently mined, the maximum thickness is $60 \mathrm{~cm}$. Bed $\mathrm{E}$ ranges in color from yellowish green to cream to greenish gray. The overburden of the bentonite, where it has been mined, ranges from 1 to $2 \mathrm{~m}$.

The stratigraphic position of Bed $\mathrm{E}$ in relation to the Clay Spur Bentonite Bed makes it useful in locating prospective mining sites. In Crook Co., Wyo., and Carter Co., Mont., the interval between the Clay Spur Bentonite Bed and Bed E is 8-9 m, indicating that there is less than $9 \mathrm{~m}$ of overburden above the Clay Spur Bentonite Bed. In Butte Co., S. Dak., the interval between the Clay Spur Bentonite Bed and Bed E thins to $5.6 \mathrm{~m}$ near Belle Fourche. The X-ray diffraction trace of a sample from Bed $\mathrm{E}$ shows the presence of quartz and cristobalite.

Bed F.-Bentonite Bed F, in the upper part of the Belle Fourche Shale, is called the "Gray Red" bentonite bed in some reports because of its characteristic coloration over a large part of the northern district. Bed $F$ appears to be continuous throughout the northern district and averages about $1.2-1.5 \mathrm{~m}$ in thickness but is locally as thick as $2 \mathrm{~m}$. Bed F consists of waxy bentonite containing trace amounts of small flakes of biotite, grains of feldspar, quartz, and calcite, and traces of other nonclay minerals. The clay is generally light gray to buff, but some of it in the western part of the northern district is stained red by small amounts of iron oxide. Spheroidal limestone concretions as much as $1 \mathrm{~m}$ in diameter, which are common in Bed $\mathrm{F}$, cause problems in mining; some are separated during loading of the clay, and some are removed by mechanized equipment from the stock pile.

Bed $F$ is overlain and underlain by shale. The bentonite grades upward into soft dark-gray shale through a zone of interlaminated dark shale and bentonite ranging in thickness from 20 to $25 \mathrm{~cm}$. In most places the bed is in sharp contact with the underlying soft dark-gray shale. Locally, the bentonite and shale are separated by about $2.5-10 \mathrm{~cm}$ of siliceous shale, in which the silica was believed to have been leached from the overlying ash bed during its conversion to bentonite.
Bed I.-Bentonite Bed I, in the northern district, is known as the Ardmore bentonite bed in Fall River County, S. Dak., and correlates with the Pedro bentonite bed in the Newcastle area, Weston County, Wyo. This bed occurs at the base of the black shale of the Mitten Member of the Pierre Shale (fig. 8) approximately $700 \mathrm{~m}$ stratigraphically higher than the Clay Spur Bentonite Bed. It is a composite bed of bentonite and several partings of dark-gray fissile shale. The bed, including the partings, ranges in thickness from $1 \mathrm{~m}$ on the west side of the northern district to more than $3 \mathrm{~m}$ near the east margin of the district. In general, the shale partings do not exceed a total of $23 \mathrm{~cm}$; the bentonite layer near the base has an average thickness of $1 \mathrm{~m}$, and the middle and upper bentonite layers are thin and sporadic.

Bed I consists chiefly of montmorillonite in which calcium is the principal exchangeable cation. Much of the bed contains small crystals of secondary fibrous selenite, particularly along joints. In the eastern part of the district, the upper part of the bed contains concretions that range in diameter from $20-60 \mathrm{~cm}$. Some of these concretions consist of calcite; others consist of gypsum, stained by limonite.

Unweathered bentonite is mostly greenish gray, and because of the small amount of iron, the clay weathers to shades of yellow and orange with reddish-brown films along many joint surfaces. The X-ray diffraction trace of a sample from Bed I indicated that the bed is composed of montmorillonite, with some gypsum, and a small amount of biotite.

\section{KAYCEE AREA}

The bentonite deposits on the western side of the Powder River Basin are on the eastern flank of the Bighorn Mountains, near the small town of Kaycee, Johnson County, Wyo. (no. 36, pl. 1). Kaycee was the focal point of the Johnson County War, which developed from the conflict between the cattle ranchers and sheep ranchers in the 1890's. Bentonite mining near Kaycee began in 1935, and except for the period 1942-47, bentonite has been produced from this area.

Five bentonite beds have been mined in the Kaycee area for use as a binder for pelletizing iron ore, as animal feed, as foundry-sand bond, and as drilling mud (Osterwald and others, 1966). According to Thorson (1976, p. 255), the five bentonite beds are all in the Mowry Shale, with the upper bed at the contact between the Mowry Shale and the Frontier Formation. However, since the upper bed is above the Clay Spur Bentonite Bed, it may be equivalent to Bed $\mathrm{E}$ that is mined in the Western Black Hills district. The underlying bentonite bed, which is correlated with the Clay Spur Bentonite Bed of the Black Hills district, is at the Mowry Shale-Frontier 
Formation contact. The three bentonite beds below the Clay Spur Bentonite Bed cannot be correlated with any beds in the Black Hills district, but Thorson (1976, p. 254) believes that they may be correlative with the Mowry Shale bentonite beds in the Bighorn District.

The two lowest unnamed bentonite beds in the Mowry Shale were about $76 \mathrm{~cm}$ and $46 \mathrm{~cm}$ thick, having about 30 $\mathrm{cm}$ of shale between. About $16 \mathrm{~m}$ above these beds was another unnamed bentonite bed having a thickness of 81 $\mathrm{cm}$. The Clay Spur Bentonite Bed was about $102 \mathrm{~m}$ above the third unnamed bed, and bentonite Bed $\mathrm{E}$ was approximately $3.5 \mathrm{~m}$ above the Clay Spur. The bentonites ranged in color from yellowish gray and cream where weathered or oxidized to olive gray and medium gray where unweathered or unoxidized.

\section{BIGHORN DISTRICT}

The Bighorn district, on the eastern edge of the Bighorn Basin in Carbon County (no. 30, pl. 1), Mont., and Big Horn (no. 34, pl. 1) and Washakie Counties (no. 35 , pl. 1), Wyo., is approximately $175 \mathrm{~km}$ long. The district extends from about $7 \mathrm{~km}$ south of Bridger, Mont., southeast to near Ten Sleep, $35 \mathrm{~km}$ east of Worland, Wyo. (Thorson, 1983). Large-scale mining and processing of bentonite in the eastern Bighorn Basin began in the early 1950 's to supply two plants, Dresser Minerals (now M. I. Drilling Fluids Company) and WyoBen, Inc., near Greybull (34, pl. 1), Wyo. (O'Driscoll, 1988, p. 67). Later three plants, American Colloid Company, N L Industries, Inc., and Wyo-Ben, Inc., were built at Lovell (34, pl. 1), and Kaycee Bentonite Partnership at Worland (no. 35, pl. 1).

The bentonite beds mined in the Bighorn district are in the Cretaceous Thermopolis Shale, Mowry Shale, and Frontier Formation (fig. 8). Other bentonite beds, of poor quality and noncommercial, occur in the Morrison Formation (Jurassic), Cody Shale and Meeteetse Formation (Cretaceous), and Fort Union (Paleocene) Formation (Rioux, 1958). The bentonite beds that are mined crop out along the entire eastern margin of the Bighorn Basin. At most places, these beds have gentle dips, but beds dipping westward more than $35^{\circ}$ have been mined on the western flank of Pryor Mountain on both sides of the Montana-Wyoming border.

As many as four bentonite beds have been mined from the upper part of the Thermopolis Shale and the overlying Mowry Shale about $25 \mathrm{~km}$ east of Lovell. Two bentonite beds in the Frontier Formation have been mined in the area extending from $25 \mathrm{~km}$ northeast of Greybull to near Ten Sleep. According to Thorson (1983), a bentonite bed in the Frontier Formation and the one near the contact between the Mowry Shale and the Frontier Formation are by far the most important economically.

The lowest bentonite bed mined is in the Shell Creek Member of Eicher (1960, p. 17), the upper member of the Thermopolis Shale, and is approximately $67 \mathrm{~m}$ above the underlying Muddy Sandstone Member of the Thermopolis Shale. This bed, known locally as the Rusty or Tan bed, is $75-90 \mathrm{~cm}$ thick and contains small lenses and nodules of siderite. Approximately $15.5 \mathrm{~m}$ above the Rusty bed is another economic bentonite bed at the contact of the Thermopolis Shale with the overlying Mowry Shale. This bed is light gray, $60-90 \mathrm{~cm}$ thick, and locally is called bed E. Twenty-five meters above this bed is a greenish-gray bentonite $90-135 \mathrm{~cm}$ thick, informally called the Canadian bed, which has been mined to some extent. About $49 \mathrm{~m}$ above the Canadian bed is the informally named Commercial bentonite bed, which is the most extensively mined bed in the area. The Commercial bed is greenish gray, $75-90 \mathrm{~cm}$ thick, and overlain by $30 \mathrm{~cm}$ of gray shaly bentonite. The Commercial bed may be correlative with the Clay Spur Bentonite Bed of the Mowry Shale, which has been mined extensively in the Black Hills region. Between the Canadian and Commercial beds, at least three beds of low-grade bentonite occur.

A bed of high-grade bentonite, $60 \mathrm{~cm}$ to $4 \mathrm{~m}$ in thickness, occurs above the Peay Sandstone Member in the lower part of the Frontier Formation. This bed, called the Stucco bentonite by Rioux (1958, p. 98), has been mined in the vicinity of Greybull. Goodell (1962, p. 182) and Rioux (1958, p.169) have tentatively correlated the Stucco bentonite bed with the Soap Creek bentonite bed of the Belle Fourche Shale (see section on the Hardin District, Mont.). A second bentonite 1 to $2.7 \mathrm{~m}$ thick is also mined in the Greybull area. This bed occurs below the Torchlight Sandstone Member of the Frontier Formation.

\section{CASPER AREA}

Four deposits of Mowry Shale bentonite occur in the Casper area, Natrona County (no. 37, pl. 1), Wyo.: the Emigrant Gap, Alcova, Bates Park, and Bates Creek deposits (Dengo, 1946). Emigrant Gap was the only deposit being mined in the mid-1980's. The most important bentonite bed in these deposits is the Clay Spur Bentonite Bed at the contact between the Mowry Shale and the Frontier Formation. At Emigrant Gap, sec. 9, T. 33 N., R. 81 W., the Clay Spur Bentonite Bed is yellow on weathered surfaces, is greenish yellow on fresh surfaces, and is about $137 \mathrm{~cm}$ thick. At Alcova, at the east side of the Alcova reservoir, sec. $30, T .30$ N., R. 82 W., the Clay Spur Bentonite Bed is light cream in color 
and is about $152 \mathrm{~cm}$ thick. At Bates Park, along the Bolton Creek road, secs. 10 and 15, T. 30 N., R. 81 W., the Clay Spur Bentonite Bed is about $152 \mathrm{~cm}$ thick and cream colored on fresh surfaces and yellow on weathered surfaces. At Bates Creek, along the Medicine Bow road, secs. 26, 35, and 36, T. 32 N., R. 81 W., the Clay Spur bentonite also is yellow on weathered surfaces, greenish yellow on fresh surfaces, and about $137 \mathrm{~cm}$ thick. The bentonite is processed for drilling mud and for pelletizing iron ore by the Kaycee Bentonite Partnership at Mills, Natrona County (O'Driscoll, 1988, p. 67).

\section{NEWCASTLE AREA}

Approximately $38.5 \mathrm{~km}$ south of Newcastle, Weston County (no. 33, pl. 1), Wyo., are several old bentonite pits about $1 \mathrm{~km}$ north of the Weston-Niobrara County line. According to Brobst (1961, pl 5), the bentonite occurs in the Belle Fourche Shale of Late Cretaceous age. The dark-gray bentonite bed exposed in these pits is $38-51 \mathrm{~cm}$ thick and has a $5-15 \mathrm{~cm}$ unit of siderite at the base. The bed is overlain by gray shale that contains many siderite nodules. A sample from one of the pits contains 94 percent clay, 6 percent silt, and a trace of sand. The clay fraction is montmorillonite. The pits in this area appear to be prospects, and it is doubtful that any bentonite has been mined. According to Brobst (1961, p. 56), the bentonite bed is not commercial because it is too thin and the overburden too thick.

The Pedro Bentonite Bed, exposed in the Newcastle area of Wyoming (Maple and Pilmore, 1963, p. N55), is in a zone up to $21 \mathrm{~m}$ thick and contains 14 bentonite beds. The basal bentonite bed, called the Pedro Bentonite Bed by Rubey (1931, p. 4), which is about $9 \mathrm{~m}$ thick, occurs at the base of the black shale of the Mitten Member of the Pierre Shale, and it correlates with the Ardmore Bentonite Bed of Spivey (1940) in South Dakota and Bed I of Knechtel and Patterson (1962, p. 990) in the Northern Black Hills district. Based on this correlation, the name Pedro Bentonite Bed was later abandoned by Schultz and others (1980) in favor of the Ardmore Bentonite Bed. The Ardmore Bentonite Bed consists of nonswelling or very low swelling calcium-bentonite. One sample taken from near Pedro, Weston County, Wyo., contains 6.35 percent calcium oxide (Wells, 1937, p. 71). A small amount of bentonite was mined from the Ardmore Bentonite Bed in secs. 8 and 9, T. 45 N., R. 62 W., many years ago (Maple and Pilmore, 1963, p. N77).

\section{BENTONITE RESOURCES}

Only a few estimates of bentonite resources in Wyoming have been published. Patterson (written commun., 1952) estimated the bentonite resources in Crook County, Wyo., as follows: Bed A, 8.2 Mt; Clay Spur
Bentonite Bed, 46.3 Mt; Bed F, 8.2 Mt; and a total of 62.7 Mt. These estimates are based on bentonite with 30 percent water under less than $10 \mathrm{~m}$ of overburden. Probably about one-half of this estimated amount of bentonite in Crook County has been mined since 1952 . The total bentonite resources on claims and leases in the entire State of Wyoming were estimated by Regis and Montgomery (1979) to be as much as 1,675 Mt. They gave accuracy estimates of low, middle, and high for the amount of bentonite in place, containing approximately 30 percent water and under less than $22.9 \mathrm{~m}$ of overburden, and for the amount of bentonite that would be processed. Their estimates, in million metric tons, are as follows:

\begin{tabular}{|c|c|c|c|}
\hline & High & Middle & Low \\
\hline Bentonite in place & 1,846 & 1,269 & 1,147 \\
\hline Bentonite processed & 1,465 & 1,002 & 907 \\
\hline
\end{tabular}

Other estimates for the total resources of bentonite in Wyoming include $181 \mathrm{Mt}$ (Ampian, 1985, p. 158) and 91 Mt by Thorson (1976). Neither author specified whether their estimates were based on bentonite in place, bentonite that could be processed, or overburden limitations.

\section{CONCLUSION}

For more than $20 \mathrm{yr}$, the annual production of bentonite increased at a annual rate of 12 percent to reach a high of 4.5 Mt in 1981. In 1982 and 1983, production declined to a low of $2.6 \mathrm{Mt}$, and since 1983 , there has been no indication of a sustained growth in bentonite production. The annual production rate for fuller's earth has averaged 14 percent for more than $30 \mathrm{yr}$ and will probably continue at almost this rate during the 1990's.

Ampian (1985, p. 159) indicates that the bentonite reserves in the United States are about $800 \mathrm{Mt}$. Montana, Wyoming, and South Dakota, the only source of sodium-bentonite in the United States, have had a continuous production for over $75 \mathrm{yr}$; therefore, the resources of high-quality swelling bentonite from Wyoming and Montana are declining. California has been the major source of hectorite, and, because there has been production for almost $60 \mathrm{yr}$, the resources of hectorite are being depleted. Alabama, Arizona, Mississippi, and Texas have been the principal producers of the nonswelling calcium-bentonite, and their resources are probably adequate for many years. The demand for bentonite for use as a drilling mud has decreased and will continue to decrease as the United States becomes more dependent on foreign petroleum. If organic binders (that is, gelled starch) prove to be a better binder than bentonite for 
pelletizing iron ores (Haas and others, 1989), then the decreased demand for bentonite may cause an additional decrease in production.

Any estimate of fuller's earth reserves is purely conjectural. Ampian (1985, p. 159) indicates that the reserves of fuller's earth is $4 \mathrm{Gt}$. The annual production of fuller's earth reached a high of almost $2 \mathrm{Mt}$ in 1988. The principal producers of palygorskite-type fuller's earth are Georgia and Florida. States with bentonitetype fuller's earth resources in the Porters Creek Clay are Missouri, Illinois, Kentucky, Tennessee, and Mississippi. Other States having bentonite-type fuller's earth resources are Georgia (Twiggs Clay Member), Nevada, South Carolina (Black Mingo Formation), Texas (Claiborne Group), and Virginia and Maryland (Calvert Formation). The resources of both types of fuller's earth are probably adequate for many years. The demand for fuller' earth for absorbing oil, grease, and pet waste and for filtering and clarifying will probably continue to increase.

New markets for bentonite and fuller's earth specialty products will continue to develop and grow (Eyde, 1986), such as (1) the development of pillared clays for use as a catalyst, (2) the development of organophillic clays for use as clay gellents or thickeners for greases and other petroleum products, (3) synthetic bentonite and hectorite for use in catalytic cracking, and (3) a demand by consumers for high-purity clays processed into more efficient products. The demand for washed or otherwise purified white bentonite for specialty products will also increase.

\section{REFERENCES CITED}

Albers, J.P., and Stewart, J.H., 1965, Preliminary geologic map of Esmeralda County, Nevada: U.S. Geological Survey, Mineral Investigation Field Studies Map, MF-298.

1972, Geology and mineral deposits of Esmeralda County, Nevada: Nevada Bureau of Mines and Geology, Bulletin 78, 80 p.

Allen, J.E., 1955, Mineral resources of the Navajo Reservation in New Mexico (exclusive of uranium, coal, oil, gas, and water): New Mexico Bureau of Mines and Mineral Resources, Bulletin 44, map.

American Oil Chemists Society, 1958, Bleaching tests: A.O.C.S. Official Method, Ce 8a 52, American Oil Chemists Society, 2 p.

Ames, L.L., Jr., Sand, L.B., and Goldich, S.S., 1958, A contribution on the Hector, California bentonite deposit: Economic Geology, v. 53, p. 22-37

Ampian, S.G., 1985, Clays, in Mineral facts and problems: U.S. Bureau of Mines, Bulletin 675, p. 157-169.

1988, Clays, in U.S. Bureau of Mines Yearbook 1986: Washington, D.C., v. 1, p. 245-279.

Anderson, A.L., 1956, Geology and mineral resources of the Salmon quadrangle, Lemhi County, Idaho: Idaho Bureau of Minewand Geology, Pamphlet 106, $102 \mathrm{p}$.

1959, Geology and mineral resources of the North Fork quadrangle, Lewis County, Idaho: Idaho Bureau of Mines and Geology, Pamphlet 118, $92 \mathrm{p}$.
Archibold, N.L., 1966, Industrial mineral deposits of Mineral County, Nevada: Nevada Bureau of Mines, Report 14, 32 p.

1969, Industrial mineral deposits, in Moore, J.G., Geology and mineral deposits of Lyons, Douglas, and Ormsby Counties, Nevada: Nevada Bureau of Mines, Bulletin 75, p. 31-41.

Arndt, B.M., 1975, Geology of Cavalier and Pembina Counties: North Dakota Geological Survey, Bulletin 62, pt. I, 68 p.

Asher, R.R., 1965, Volcanic construction materials in Idaho: Idaho Bureau of Mines and Geology, Pamphlet 135, $150 \mathrm{p}$.

Aune, Q.A., Caraway, W.H., Morris, F.C., and Gates, G.L., 1959, Evaluation of a California bentonitic clay for use in oil-well drilling muds: U.S. Bureau of Mines, Report of Investigation 5487, $44 \mathrm{p}$.

Bay, H.X., 1940, The bleaching clay of Georgia, in Clay investigations in the southern States: U.S. Geological Survey Bulletin 901, p. 252-300.

Beg, M.A., Bearden, B.L., Clarke, O.M., Jr., Barnett, R.L., and Daniel, T.W., Jr., 1986, Summary report on the mineral resources of southeast Alabama: Geological Survey of Alabama, Information Series 65, $33 \mathrm{p}$.

Berg, R.B., 1969, Bentonite in Montana: Montana Bureau of Mines and Geology, Bulletin 74, $34 \mathrm{p}$.

-1970, Bentonite deposits in the Ingomar-Vananda area, Treasure and Rosebud Counties, Montana: Montana Bureau of Mines and Geology, Special Publication 51, 5 p.

Bicker, A.R., Jr., 1970, Economic minerals of Mississippi: Mississippi Geological, Economic and Topographical Survey, Bulletin 112, 80 p.

Bluemle, J.P., 1973, Geology of Nelson and Walsh Counties, North Dakota: North Dakota Geological Survey, Bulletin 57, pt. I, 70 p.

Bohor, B.F., and Khandelwal, Suresh, 1968, A new use for Illinois clay materials in pesticide formulations: Illinois State Geological Survey, Industrial Minerals Notes $33,13 \mathrm{p}$.

Bradley, W.F., 1940, The structural scheme of attapulgite: American Mineralogist, v. 25 , no. 6 , p. $405-410$.

Brindley, G.W., 1957, Fuller's earth from near Dry Branch, Georgia, a montmorillonite-cristobalite clay: Clay Minerals Bulletin [Great Britain], v. 3, no. 18 , p. 167-169.

Brobst, D.A., 1961, Geology of the Dewey quadrangle, WyomingSouth Dakota: U.S. Geological Survey Bulletin 1063-B, p. 13-60.

Buie, B.F., Hetrick, J.H., and Patterson, S.H., 1979, Geology and industrial mineral resources of the Macon-Gordon kaolin district, Georgia: U.S. Geological Survey Open-File Report 79-526, 36 p.

California Division of Mines and Geology, 1987, Mines and mineral producers active in California during 1986: California Division of Mines and Geology, Special Publication 93, 99 p.

Campbell, K.M., 1986, Industrial minerals of Florida: Florida Bureau of Geology, Information Circular 102, $94 \mathrm{p}$.

Carver, R.E., 1972, Absorption of opaline clays from the Eocene of Georgia, in Puri, H.S., ed., Geology of phosphate, dolomite, limestone and clay deposits: Florida Bureau of Geology, Special Publication 17, p. 91-101.

Castor, S.B., 1989, Industrial minerals, in the Nevada mineral industry: Nevada Bureau of Mines and Geology, Special Publication MI-1988, p. 27-30.

Chelf, C.R., 1942, Bleaching clay deposits in Gonzales County, Texas: Texas University Bureau of Economic Geology, Mineral Resource Survey Circular 43 , p. ii.

Clarke, O.M., Jr., 1970, Clays of southeastern Alabama: Geological Survey of Alabama, Circular 20-E, $97 \mathrm{p}$.

Clarke, O.M., Jr., and Tyrell, M.E., 1976, Porters Creek lightweight aggregate: Geological Survey of Alabama, Circular 100, 35 p.

Clay and Clay Minerals, 1971, Summary of national and international recommendations on clay mineral nomenclature, 1969-70 CMS Nomenclature Committee: Clays and Clay minerals, v. 19, p. 129-132. 
Cleveland, G.B., 1957, Clay, in Mineral commodities of California: California Division of Mines, Bulletin 176, p. 131-152.

-1960, Geology of the Otay bentonite deposit, San Diego County, California: California Division of Mines, Special Report 64, $16 \mathrm{p}$.

1966, Diatomite in Mineral and Water Resources of California, Report for the Committee on Interior and Insular Affairs, U.S. Senate: U.S. Congress, 89th, $2 \mathrm{~d}$ session, Committee Print, p. 151-158.

Coats, R.R., 1987, Geology of Elko County, Nevada: Nevada Bureau of Mines and Geology, Bulletin 101, 112 p.

Colquhoun, D.J., Heron, S.D., Johnson, H.S., Pooser, W.K., and Siple, G.E., 1969, Up-dip Paleocene-Eocene stratigraphy of South Carolina reviewed: South Carolina State Development Board, Geologic Notes, v. 13, no. 1, 26 p.

Condra, G.E., 1908, Geology and water resources of a portion of the Missouri River valley in northeastern Nebraska: U.S. Geological Survey Water-Supply Paper 215, $59 \mathrm{p}$.

Connolly, J.P., and O'Harra, C.C., 1929, The mineral wealth of the Black Hills: South Dakota School of Mines, Bulletin 16, $418 \mathrm{p}$.

Connor, J.J., 1963, Geology of the Angostura Reservoir quadrangle, Fall River County, South Dakota: U.S. Geological Survey Bulletin 1063-D, p. 85-126.

Corcoran, R.E., Doak, R.A., Porter, P.W., Prichett, F.L., and Privrasky, N.C., 1962, Geology of the Mitchell Butte quadrangle, Oregon: Oregon Department of Geology and Mineral Industries, Geological Map Series GMS-2, scale 1:125,000.

Cornwall, H.R., and Kleinhampl, F.J., 1964, Geology of Bullfrog quadrangle and ore deposits related to Bullfrog Hills caldera, Nye County, Nevada: U.S. Geological Survey Professional Paper $454-\mathrm{J}, 25 \mathrm{p}$.

Darton, N.H., and Siebenthal, C.E., 1909, Geology and mineral resources of the Laramie basin, Wyoming: U.S. Geological Survey Bulletin $364,81 \mathrm{p}$.

Davis, J.C., 1965, Bentonite deposits of the Clay Spur district, Crook and Weston Counties, Wyoming: Wyoming Geological Survey Preliminary Report No. 4, 17 p.

Dengo, Gabriel, 1946, Geology of bentonite deposits near Casper, Natrona County, Wyoming: Wyoming Geological Survey Bulletin $37,28 \mathrm{p}$.

Denny, C.S., and Drewes, Harald, 1965, Geology of the Ash Meadows quadrangle, Nevada-California: U.S. Geological Survey Bulletin $1181-\mathrm{L}, 56 \mathrm{p}$.

Dibble, T.W., Jr., 1958, Tertiary stratigraphic units of western Mojave Desert, California: American Association of Petroleum Geologists Bulletin, v. 42, no. 1, p. 135-144.

Dibble, T.W., Jr., and Gay, T.E., 1952, Mineral deposits of Saltdale quadrangle: California Division of Mines, Bulletin 160, p. 45-64.

Dietrich, J.W., and Lonsdale, J.T., 1958, Mineral resources of the Colorado River Industrial Development Association Area, Texas: Texas University Bureau of Economic Geology, Report of Investigations $37,84 \mathrm{p}$.

Dixon, L.H., 1967, Clay resources of Louisiana-Test data and evaluation of miscellaneous clays: Louisiana Geological Survey, Clay Resource Bulletin 1, $107 \mathrm{p}$.

Doelling, H.H., 1975, Geology and mineral resources of Garfield County, Utah: Utah Geological and Mineralogical Survey, Bulletin $107,175 \mathrm{p}$.

Eicher, D.L., 1960, Stratigraphy and micropalentology of the Thermopolis Shale: Yale University, Peabody Museum of Natural History, Bulletin 15, $126 \mathrm{p}$.

Endleman, Henry, 1858, Report of a geological exploration from Fort Leavenworth to Bryan's Pass, made in connection with the survey of a road from Fort Riley to Bridger's Pass, under command of lieutenant F.I. Bryan, topographic engineer, 1856, in Report of the Secretary of War, 1857: U.S. Congress, 35th, 1st session, p. 489-517.

Eyde, D.T.,1986, Speciality clays-The search for excellence, in Clarke, G.M., and Griffiths, J.B., eds., Industrial Minerals: 7th Industrial Minerals International Congress, April, 1-4, 1986, London, Chameleon Press, p. 153-157.

Eyde, D.T., and Eyde, T.H., 1987, Geology and mining of the Cheto bentonite deposit, Apache County, Arizona, in Mumpton, F.A., ed., Zeo-trip 1987; An excursion to selected zeolite and clay deposits in southwestern New Mexico and western Arizona: International Committee on Natural Zeolites, p. 47-54.

Eyde, T.H., 1989, Potential growth for the industry, in Tooker, E.W., ed., Arizona's industrial rock and mineral resources-Workshop proceedings: U.S. Geological Survey Circular 1905, p. 11-14.

Farrar, Willard, Grenfell, D.S., and Allen, V.T., 1935, The geology and bleaching clays of southeast Missouri: Missouri Geological Survey and Water Resources 58th Biennial Report, Appendix 1, 78 p.

Fersman, A., 1913, Studies in magnesium silicates: Memoirs of the Academy of Science, St. Petersburg, ser. 8, v. 32, p. 323-365.

Fisher, W.L., 1965, Rock and mineral resources of East Texas: Texas University Bureau of Economic Geology, Report of Investigations $54,439 \mathrm{p}$.

Fleming, K.L., and Jones, R.B., 1989, Directory of mining and milling operations, in the Nevada mineral industry: Nevada Bureau of Mines and Geology, Special Publication MI-1988, p. 31-44.

Frahme, C.W., 1978, Sample localities and physical and chemical test data for some bentonites from Wyoming and Montana: U.S. Geological Survey Open-File Report 78-81, 42 p.

Galbraith, F.W., and Brennan, D.J., 1959, Minerals of Arizona: Arizona University Bulletin, v. 30, no. 2, Physical Science Bulletin 4, $116 \mathrm{p}$.

Goodell, H.G., 1962, The stratigraphy and petrology of the Frontier Formation of Wyoming, in Enyert, R.L., and Curry, W.H., III, eds., Symposium on early Cretaceous rocks of Wyoming and adjacent areas: Wyoming Geological Association, 17th Annual Field Conference Guidebook, p. 173-210.

Goodyear, W.A., 1890, San Diego County: California Mining Bureau, Report 9, p. 139-154.

Gray, J.J.., 1990, Oregon bentonite, in Geitgey, R.P., and Vogt, B.F., eds., Industrial rocks and minerals of the Pacific Northwest: Oregon Department of Geology and Mineral Industries, Special Paper 23, p. 14-18.

Gray, J.J., Geitgey, R.P., and Baxter, G.L., 1989, Bentonite in Oregon-Occurrences, analyses, and economic potential: Oregon Department of Geology and Mineral Industries, Special Paper 20, $28 \mathrm{p}$.

Grim, R.E., 1962, Applied clay mineralogy: New York, McGraw-Hill Book Co., $422 \mathrm{p}$.

1968, Clay mineralogy, 2d ed.: New York, McGraw-Hill Book Co., $596 \mathrm{p}$.

Grim, R.E., and Güven, Necip, 1978, Bentonites, geology, mineralogy, properties and uses: New York, Elsevier, $256 \mathrm{p}$.

Haas, L.A., Aldinger, J.A., and Zahl, R.K., 1989, Effectiveness of organic binders for iron ore pelletization: U.S. Bureau of Mines, Report of Investigations, RI 9230, $21 \mathrm{p}$.

Hall, R.B., and Starkey, H.C., 1985, Western Clay Company, Aurora, Utah, fuller's earth and bentonite, in Fieldtrip Guidebook for Clays and Clay Minerals, western Colorado and eastern and central Utah: 1985 International Clay Conference, July 28-August 2, 1985, Denver, Colorado, p. 24-30.

Hansen, D.E., and Kume, Jack, 1970, Geology and ground-water resources of Grand Forks County, pt. I, Geology: North Dakota Geological Survey, Bulletin 53, $76 \mathrm{p}$. 
Heathman, J.H., 1939, Bentonite in Wyoming: Wyoming Geological Survey, Bulletin 28, $20 \mathrm{p}$

Heron, S.D., Jr., Robinson, G.C., and Johnson, H.S., Jr., 1965, Clays and opal-bearing claystones on the South Carolina Coastal Plain: South Carolina State Development Board, Bulletin 31, 64 p.

Hertlein, L.G., and Grant, U.S., IV, 1939, Geology and oil possibilities of southwestern San Diego County: California Mines and Geology, Journal, v. 35, no. 1, p. 57-78.

Hetrick, J.H., 1982, Clay mineral distributions in the central Georgia kaolin district: Georgia Geologic Survey, Open-File Report, 82-4, $57 \mathrm{p}$.

Hewitt, D.F., 1917, The origin of bentonite: Washington Academy of Science Journal, v. 7, p. 196-198.

Hosterman, J.W., 1984, Ball clay and bentonite deposits of the central and western Gulf of Mexico Coastal Plain, United States: U.S. Geological Survey Bulletin 1558-C, 22 p.

1985, Bentonite and fuller's earth resources of the United States: U.S. Geological Survey Mineral Investigations Resource Map MR-92, scale 1:5,000,000.

Hosterman, J.W., and Flanagan, F.J., 1987, USGS reference samples attapulgite ATT-1 and bentonite CSB-1: Geostandards Newsletter, v. 11 , no. 1, p. 1-9.

Hosterman, J.W., and Livingston, V.E., Jr., 1966, Clays, in Mineral and water resources of Washington, Report for the Committee on Interior and Insular Affairs, U.S. Senate: U.S. Congress, 89th, 2d session, Committee Print, p. 177-185.

Hosterman, J.W., and Prater, L.S., 1964, Clays, in Mineral and water resources of Idaho, Report for the Committee on Interior and Insular Affairs, U.S. Senate: U.S. Congress, 88th, 2d session, Committee Print, p. 51-57.

Huddlestun, P.F. and Hetrick, J.H., 1979, The stratigraphy of the Barnwell Group of Georgia: Georgia Geological Survey, Open-File Report 80-1, $89 \mathrm{p}$.

Johnson, Joseph, 1937, Mineral resource survey of Angelina and Cherokee Counties: Texas University Bureau of Economic Geology, Mineral Resource Survey Circular 17, 3 p.

Johnson, K.S., 1969, Mineral map of Oklahoma: Oklahoma Geological Survey Map GM-15, scale 1:750,000.

Johnson, M.G., 1977, Geology and mineral deposits of Pershing County, Nevada: Nevada Bureau of Mines and Geology, Bulletin $89,115 \mathrm{p}$.

Johnson, S.S., and Tyrrell, M.E., 1967, Analyses of clay and related materials-Eastern counties: Virginia Division of Mineral Resources, Mineral Resources Report 8, $232 \mathrm{p}$.

Karl, V.E., 1951, Mineral resources of Nye County, Nevada: University of Nevada, Bulletin, v. 45, no. 3, Geology and Mining Series no. $50,223 \mathrm{p}$.

Kelley, F.R., 1966, Clay, in Mineral and Water Resources of California, Report for the Committee on Interior and Insular Affairs, U.S. Senate: U.S. Congress, 89 th, $2 d$ session, Committee Print, p. 126-134.

Kerr, P.F., and Cameron, E.N., 1936, Fuller's earth of bentonitic origin from Tehachapi, California: American Mineralogist, v. 21, p. 230-237.

Kiersch, G.A., and Keller, W.D., 1955, Bleaching clay deposits, in Kiersch, G.A., ed., Mineral Resources, Navajo-Hopi Reservations, Arizona-Utah, v. 2, Nonmetallic minerals, geology, evaluation, and uses: University of Arizona Press, Tucson, Arizona, p. 41-54.

King, P.B., 1940, Clay deposits of the San Antonio area and Morris County, Texas: U.S. Geological Survey Bulletin 901, p. 93-188.

Kinney, E.D., 1942, Kansas bentonite-Its properties and utilization, in 1942 Reports of studies: State Geological Survey of Kansas, Bulletin 41, p. 349-376.
Kirkham, V.R.D., 1927, A geologic reconnaissance of Clark, Jefferson, and parts of Butte, Custer, Fremont, Lemhi, and Madison Counties Idaho: Idaho Bureau of Mines and Geology, Pamphlet 19, $47 \mathrm{p}$.

Knechtel, M.M., and Hosterman, J.W., 1965, Outlook for resumption of diatomite in southern Maryland and eastern Virginia: U.S. Geological Survey Professional Paper 525-D, p. D151-D155.

Knechtel, M.M. and Patterson, S.H., 1956, Bentonite deposits in Marine Cretaceous formations, Hardin district, Montana and Wyoming: U.S. Geological Survey Bulletin 1023, 116 p.

1962, Bentonite deposits of the northern Black Hills district, Wyoming, Montana, and South Dakota: U.S. Geological Survey Bulletin 1082-M, $1030 \mathrm{p}$.

Knight, W.C., 1898, Bentonite: Engineering and Mining Journal, v. 66 , no. 17, p. 491

Kuper, H.T., and Farrand, G.T., 1977, Geology of southwestern San Diego County, California-Field trip, in Farrand, G.T., ed., Geology of southwestern San Diego County, California and northwestern, Baja California: San Diego Association of Geologists, San Diego, California, p. 81-85.

Lamar, J.E., 1928, Preliminary report on the fuller's earth deposits of Pulaski County: Illinois State Geological Survey, Report of Investigation $15,31 \mathrm{p}$.

Lapparent, Jacques de, 1935, Sur un constituent essential des terres foulon: Academy of Science Paris, Comptes Rendus, v. 201, p. 481-483.

1936, Formule et schema structural de l'attapulgite: Academy of Science Paris, Comptes Rendus, v. 201, p. 1728-1731.

Larsen, D.H., 1955, Use of clay in drilling fluids, in Pask, J.A., and Turner, M.D., eds., Clays and clay technology: California Division of Mines Bulletin 169, p. 269-281.

Larsen, E.S., 1930, Recent mining developments in the Creede district, Colorado: U.S. Geological Survey Bulletin 811-B, p. 89-112.

Leppert, Dave, 1985, Zeolites and bentonites: The entrepreneurial approach: Northwest Mining Association, Proceedings of the 91st Annual Convention, December 6, 1985, Spokane, Washington, Paper no. 19, $7 \mathrm{p}$.

Lohman, S.W., 1965, Geology and artesian water supply of the Grand Junction area, Colorado: U.S. Geological Survey Professional Paper 451, $149 \mathrm{p}$.

Longwell, C.R., Pampeyan, E.H., Bowyer, Ben, and Roberts, R.J., 1965, Geology and mineral deposits of Clark County, Nevada: Nevada Bureau of Mines, Bulletin 62, $218 \mathrm{p}$.

Lusk, T.W., 1956, Benton County Geology: Mississippi State Geological Survey, Bulletin 80, $104 \mathrm{p}$.

Lyons, P.L., 1957, Geology and geophysics of the Gulf of Mexico: Gulf Coast Association of Geologic Societies Transactions, v. 7, p. 1-10.

Mapel, W.J., and Pillmore, C.L., 1963, Geology of the Newcastle area, Weston County, Wyoming: U.S. Geological Survey Bulletin 1141-N, p. N1-N85.

1964, Geology of the Upton Quadrangle, Crook and Weston Counties, Wyoming: U.S. Geological Survey, Bulletin 1181-J, $54 \mathrm{p}$.

Maxwell, R.A., 1962, Mineral resources of South Texas: Texas University Bureau of Economic Geology, Report of Investigations 43, $140 \mathrm{p}$.

McGrain, Preston, 1956, Sources of fuller's-earth type clay in Kentucky: Kentucky Geological Survey, Information Circular, no. 6, 4 p.

1965, Fuller's earth resources of the Jackson Purchase Region, Kentucky: Kentucky Geological Survey, Bulletin 3, 23 p.

Melhase, John, 1926, Mining bentonite in California: Engineering and Mining Journal-Press, v. 121, no. 21, p. 837-842.

Merrill, R.K., 1983, Source of the volcanic precursor to Upper Cretaceous bentonite in Monroe County, Mississippi: Mississippi Geology, v. 3 , no. 4 , p. $1-6$. 
Middleton, Jefferson, 1921, Fuller's earth, in Mineral resources of the United States, 1918: U.S. Geological Survey, Mineral Resources U.S., 1918, pt. II, p. 135-140.

Mielenz, R.C., and King, M.E., 1955, Physical-chemical properties and engineering performance of clays, in Pask, J.A., and Turner, M.D., eds., Clays and clay technology: California Division of Mines, Bulletin 169, p. 196-254.

Miller, R.J., Gray, Floyd, Hassemer, J.R., Hanna, W.F., Brice, John III, and Schreiner, Russell, 1987, Mineral resources of the lower Burro Creek Wilderness Study Area, Mohave and Yavapai Counties, Arizona: U.S. Geological Survey Bulletin 1701-B, 22 p.

Murray, G.E., 1961, Geology of the Atlantic and Gulf coastal province of North America: New York, Harper and Brothers, $692 \mathrm{p}$.

Norman, L.A., and Stewart, R.M., 1951, Mines and mineral resources of Inyo County: California Journal of Mines and Geology, v. 47, no. 1, p. $17-223$.

Norton, J.J., 1965, Lithium-bearing bentonite deposit, Yavapai County, Arizona: U.S. Geological Survey Professional Paper 525-D, p. D163-D166.

Nutting, P.G., 1943, Absorbent clays, their distribution, properties, production, and uses: U.S. Geological Survey, Bulletin 928-C, p. $127-221$.

Odom, I.E., 1992, Hectorite in the McDermitt caldera of Nevada: Mining Engineering, v. 44, no. 6, p. 586-589.

O'Driscoll, Mike, 1988, Bentonite, overcapacity in need of markets: Industrial Minerals, no. 250, p. 43-67.

Osterwald, F.W., Osterwald, D.B., Long, J.S., Jr., and Wilson, W.H., 1966, Mineral resources of Wyoming: Geological Survey of Wyoming, Bulletin 50, $287 \mathrm{p}$.

Papke, K.G., 1970, Montmorillonite, bentonite, and fuller's earth deposits in Nevada: Nevada Bureau of Mines, Bulletin 76, $47 \mathrm{p}$.

Patterson, S.H., 1964, Clays, in Mineral and water resources of Colorado, Report for the Committee on Interior and Insular Affairs, U.S. Senate: U.S. Congress, 88th, $2 \mathrm{~d}$ session, Committee Print, p. 183-190.

1969, Clays, in Mineral and water resources of Arizona, Report for the Committee on Interior and Insular Affairs, U.S. Senate: U.S. Congress, 90th, 2d session, Committee Print, p. 324-336.

1974, Fuller's earth and other industrial mineral resources of the Meigs-Attapulgus-Quincy district, Georgia and Florida: U.S. Geological Survey Professional Paper 828, $45 \mathrm{p}$.

Patterson, S.H., and Harksen J.C., 1975, Clays, bentonite, and lightweight aggregate, in Mineral and water resources of South Dakota, Report for the Committee on Interior and Insular Affairs, U.S. Senate: U.S. Congress, 94th, 1st session, Committee Print, p. $125-132$.

Patterson, S.H., and Holmes, R.W., 1965, Clays, in Mineral and water resources of New Mexico, Report for the Committee on Interior and Insular Affairs, U.S. Senate: U.S. Congress, 89th, 1st session, Committee Print, p. 312-322.

Patterson, S.H., and Murray, H.H., 1975, Clays, in Industrial minerals and rocks: New York, American Institute of Mining, Metallurgical and Petroleum Engineers, Inc., p. 519-585.

1984, Kaolin, refractory clay, ball clay, and halloysite in North America, Hawaii, and the Caribbean region: U.S. Geological Survey Professional Paper 1306, $56 \mathrm{p}$.

Phillips, D.M., and Phillips, L.V., 1935, Production and utilization of Texas bleaching clays: The University of Texas, Bulletin 3501, p. 105-112.

Pratt, A.R., and Callaghan, Eugene, 1970, Land and mineral resources of Sanpete County, Utah: Utah Geological and Mineralogical Survey, Bulletin $85,69 \mathrm{p}$.

Price, Ester, and Brady, L.L., 1981, Directory of Kansas mineral producers: Kansas Geological Survey, Mineral Resources Series $10,83 \mathrm{p}$.
Pryor, W.A., and Glass, H.D., 1961, Cretaceous-Tertiary clay mineralogy of the Upper Mississippi embayment: Journal of Sedimentary Petrology, v. 31, no. 1, p. 38-81.

Rath, D.L., 1983, Origin and characteristics of Wyoming bentonite deposits, in Hausel, W.D., and Harris, R.E., eds., Genesis and exploration of metallic and nonmetallic mineral and ore deposits of Wyoming and adjacent areas: Wyoming Geological Survey, Public Information Circular no. 19, p. 21-22

1986, Origin and characteristics of Wyoming bentonite deposits, in Roberts, Sheila, ed., Metallic and nonmetallic deposits of Wyoming and adjacent areas, 1983 conference proceedings: Wyoming Geological Survey, Public Information Circular no. 25, p. 84-90.

Regis, A.J., 1978a, Correlation between physical properties and exchangeable chemistry of bentonites from the western United States: Bureau of Land Management, Technical Note T/N 313, $56 \mathrm{p}$.

1978b, Mineralogy, physical and exchangeable chemistry properties of bentonite from the western United States, exclusive of Montana and Wyoming: Bureau of Land Management, Technical Note $\mathrm{T} / \mathrm{N} 315,35 \mathrm{p}$.

Regis, A.J., and Montgomery, Edwin, 1979, Resource estimates of commercial grade bentonite in Montana, Wyoming, and South Dakota: American Institute of Mining, Metallurgical and Petroleum Engineers, Pre-Print 79-8.

Reynolds, D.H., 1952, Bentonite-occurrences, properties, utilization: New Mexico Miner, v. 14, no. 3, p. 9, 24-25.

Rioux, R.L., 1958, Geology of the Spence-Kane area, Big Horn County, Wyoming: University of Illinois, Ph.D. thesis, $195 \mathrm{p}$.

Robertson, R.H.S., 1986, Fuller's earth: A history of calcium montmorillonite: Hythe, Kent, UK, Volturna Press, 421 p.

Robinson, G.C., Buie, B.F., and Johnson, H.S., Jr., 1961, Common clay of the Coastal Plain of South Carolina and their use in structural clay products: South Carolina State Development Board, Bulletin 25, $71 \mathrm{p}$.

Robison, R.A., 1966, Geology and coal resources of the Tropic area, Garfield County, Utah: Utah Geological and Mineralogical Survey, Special Studies 18, $47 \mathrm{p}$.

Rogers, T.H., 1967, Geologic map of California, San Bernardino sheet: California Division of Mines, scale 1:250,000.

Ross, C.S., and Hendricks, S.B., 1945, Minerals of the montmorillonite group: U.S. Geological Survey Professional Paper 205-B, 79 p.

Ross, C.S., Miser, H.D., and Stephenson, L.W., 1929, Water-laid volcanic rock of early Upper Cretaceous age in southwestern Arkansas, southeastern Oklahoma and northeastern Texas: U.S. Geological Survey Professional Paper 154-F, p. 175-202.

Ross, C.S., and Shannon, E.V., 1926, The minerals of bentonite and related clays and their physical properties: American Ceramic Society Journal, v. 9, no. 2, p. 77-96.

Ross, D.C., 1961, Geology and mineral deposits of Mineral County, Nevada: Nevada Bureau of Mines, Bulletin 58, 98 p.

Rubey, W.W., 1931, Lithologic studies of fine-grained upper Cretaceous sedimentary rocks of the Black Hills region: U.S. Geological Survey Professional Paper 165-A, p. 1-54.

Ruppel, E.T., and Lopez, D.A., 1988, Regional geology and mineral deposits in and near the central part of the Lemhi Range, Lemhi County, Idaho: U.S. Geological Survey Professional Paper 1480, $122 \mathrm{p}$.

Samson, I.E., and Masters, J.M., 1987, Directory of Illinois mineral producers: Illinois State Geological Survey, Illinois Mineral Notes $96,151 \mathrm{p}$.

Sandy, John, Carver, R.E., and Crawford, T.J., 1966, Stratigraphy and economic geology of the Coastal Plain of the central Savannah River area, Georgia, in Geological Society of America, Southeast 
Section Annual Meeting, Athens, Georgia, April 13-16, 1966, Guidebook, Field Trip no. 3: University of Georgia, Department of Geology, Athens, Georgia, $30 \mathrm{p}$.

Sastry, K.V.S., and Fuerstenau, D.W., 1971, A laboratory method for determining the balling behavior of taconite concentrates: American Institute of Mining and Metallurgical Engineers, Transactions, v. 250, p. $64-67$.

Schultz, L.G., Tourtelot, H.A., Gill, J.R., and Boerngen, J.T., 1980, Composition and properties of the Pierre Shale and equivalent rocks, northern Great Plains region: U.S. Geological Survey Professional Paper 1064-B, p. 1-114.

Searight, W.V., Kisvarsanyi, E.B., Bush, A.L., and Patterson, S.H., 1967, Clay and shale, in Mineral and water resources of Missouri, Report for the Committee on Interior and Insular Affairs, U.S. Senate: U.S. Congress, 90th, 1st session, Committee Print, p. 106-124.

Sellards, E.H., and Gunter, Herman, 1909, The fuller's earth deposits of Galdsden County, Fla., with notes on similar deposits found elsewhere in the State: Florida Geological Survey, Annual Report 2, 1908-1909, p. 253-291.

Sloane, R.L., and Guilbert, J.M., 1967, Electron-optical study of alteration to smectite in the Cheto clay deposit, in Bailey, S.W., ed., Clays and clay minerals, Proceedings of the 15th National Conference, Clay Minerals Society, Pittsburgh, Pennsylvania: New York, Pergamon Press, p. 35-44.

Spence, H.S., 1924, Bentonite: Canada Department of Mines, Mines Branch, publication no. $626,36 \mathrm{p}$.

Spivey, R.C., 1940, Bentonite in southwestern South Dakota: South Dakota Geological Survey, Report of Investigation 36, $56 \mathrm{p}$.

Starkey, H.C., and Blackmon, P.D., 1979, Clay mineralogy of Pleistocene Lake Tecopa, Inyo County, California: U.S. Geological Survey Professional Paper 1061, 34 p.

Sweet, P.C., 1982, Virginia clay material resources: Virginia Division of Mineral Resources, Publication 36, $178 \mathrm{p}$.

1983, Directory of the mineral industry in Virginia, 1983: Virginia Division of Mineral Resources, $28 \mathrm{p}$.

Sweet, W.E., 1980, The geology and genesis of hectorite, Hector, California, in Fife, D.L., and Brown, A.R., eds., Geology and mineral wealth of the California desert, Dibble Volume: South Coast Geological Society, Santa Ana, California, p. 279-283.

Texas University, 1967, Palestine sheet: Texas University Bureau of Economic Geology, Geologic Atlas of Texas, scale 1:250,000.

1968, Beaumont sheet: Texas University Bureau of Economic Geology, Geologic Atlas of Texas, scale 1:250,000.

1974, Seguin sheet: Texas University Bureau of Economic Geology, Geologic Atlas of Texas, scale 1:250,000.

1976, Laredo sheet: Texas University Bureau of Economic Geology, Geologic Atlas of Texas, scale 1:250,000

Thorson, T.A., 1976, Bentonite mining near Kaycee, Wyoming, in Laudon, R.B., and Curry, W.H., III, eds., Geology and energy resources of the Powder River: Wyoming Geological Association, 28th Annual Field Conference Guidebook, p. 253-256.

undated, Wyoming bentonite: Black Hills Bentonite Co., 12 p. 1983, Commercial development of Big Horn Basin bentonite reserve, in Boberg, W.W., ed., Geology of the Big Horn Basin: Wyoming Geological Association, 34th Annual Field Conference Guidebook, p. 167-170.
Troxel, B.W., and Morton, P.K, 1962, Mines and mineral resources of Kern County, California: California Division of Mines and Geology, County Report 1, $370 \mathrm{p}$.

Tucker, W.B., 1926, Los Angeles field division: California State Mining Bureau, Mining in California, v. 22, p. 453-538.

Tweto, Ogden, 1979, Geologic map of Colorado: U.S. Geological Survey Special Geologic Map, Scale 1:500,000.

U.S. Bureau of Mines, 1930-89, U.S. Bureau of Mines minerals yearbooks 1930-1989: Washington, D.C., variously paginated. 1958-62, U.S. Bureau of Mines minerals area reports yearbooks 1958-62: Washington, D.C., variously paginated.

Van Sant, Joel, 1959, Refractory-clay deposits of Colorado: U.S. Bureau of Mines, Report of Investigations 5553, $156 \mathrm{p}$.

Vestal, F.E., 1943, Monroe County mineral resources: Mississippi State Geological Survey, Bulletin 57, 218 p. 1956, Panola County geology: Mississippi State Geological Survey, Bulletin $81,157 \mathrm{p}$.

Wakeman, J.S., 1972, Method for evaluation of data from the batch testing of green pellets: American Institute of Mining and Metallurgical Engineers, Transactions, v. 252, p. 83-86.

Warton, H.M., Martin, J.A., Rueff, A.W., Robertson, C.E., Wells, J.S., and Kisvarsanyi, E.B., 1969, Missouri minerals; resources, production, and forecasts: Missouri Geological Survey and Water Resources, Special Publication, no. 1, 303 p.

Wayland, T.E., 1970, Geologic occurrence and evaluation of bentonite deposits: American Institute of Mining and Metallurgical Engineers, Preprint 70-S-19, $50 \mathrm{p}$.

Weaver, C.E., 1975, Construction of limpid dolomite: Geology, v. 3, no. 8 , p. $425-428$.

Weaver, C.E., and Beck, K.C., 1972, Vertical variability in the attapulgite mining area, in Puri, H.S., ed., Geology of phosphate, dolomite, limestone and clay deposits: Florida Bureau of Geology, Special Publication 17, p. 51-90.

Wells, R.C., compiler, 1937, Analyses of rocks and minerals from the laboratory of the United States Geological Survey, 1914-36: U.S. Geological Survey, Bulletin 878, 134 p.

Welsh, R.J., 1942, Geology of Vernon Parish: Louisiana Geological Survey Geological, Bulletin 22, $90 \mathrm{p}$.

Wherry, E.T., 1917, Clay derived from volcanic dust in the Pierre of South Dakota: Washington Academy of Science, Journal, v. 7, p. 576-583.

Whitlatch, G.I., 1940, The clays of west Tennessee: Tennessee Division of Geology, Bulletin 49, $368 \mathrm{p}$.

Wilson, E.D., and Roseveare, G.H., 1949, Arizona nonmetallics, $2 d$ ed. revised: Arizona Bureau of Mines, Bulletin 155, $60 \mathrm{p}$.

Wolfbauer, C.A., 1977, Exchangeable cations in Cretaceous bentonites from Wyoming and Montana: U.S. Geological Survey Open-File Report 77-158, $38 \mathrm{p}$.

Wright, L.A., Stewart, R.M., Gay, T.E., Jr., and Hazenbush, G.C., 1953, Mines and mineral deposits of San Bernardino County, California: California Journal of Mines and Geology, v. 49, nos. 1, 2, p. 49-259.

Zap, A.D., and Clark, L.D., 1965, Bauxite in areas adjacent to and between the Springvale and Andersonville Districts, Georgia: U.S. Geological Survey Bulletin 1199-H, 10 p. 